This is the peer reviewed version of the following article: Lai, Q. and Paskevicius, M. and Sheppard, D. and Buckley, C. and Thornton, A. and Hill, M. and Gu, Q. et al. 2015. Hydrogen Storage Materials for Mobile and Stationary Applications: Current State of the Art. ChemSusChem. 8 (17): pp. 27892825, which has been published in final form at http://doi.org/10.1002/cssc.201500231. This article may be used for non-commercial purposes in accordance with Wiley Terms and Conditions for SelfArchiving at http://olabout.wiley.com/WileyCDA/Section/id-820227.htm/\#terms 


\title{
Hydrogen storage materials for mobile and stationary applications: Current state of the art
}

\author{
Qiwen Lai, ${ }^{[\mathrm{a}]}$ Mark Paskevicius, ${ }^{[\mathrm{b}],[\mathrm{cc}]}$ Drew A. Sheppard, ${ }^{[\mathrm{c}]}$, Craig E. Buckley, ${ }^{[\mathrm{c}]}$ Aaron \\ W. Thornton, ${ }^{[\mathrm{d}]}$ Matthew R. Hill, ${ }^{[\mathrm{d}]}$ Qinfen Gu, ${ }^{[\mathrm{e}]}$ Jianfeng Mao, ${ }^{[\mathrm{f}]}$ Zhenguo Huang, ${ }^{[\mathrm{f}]}$ \\ Hua Kun Liu, ${ }^{[\mathrm{f}]}$ Zaiping Guo, ${ }^{[\mathrm{f}]}$ Amitava Banerjee, ${ }^{[\mathrm{g}]}$ Sudip Chakraborty, ${ }^{[\mathrm{g}]}$ Rajeev \\ Ahuja, ${ }^{[\mathrm{g}]}$ and Kondo-Francois Aguey-Zinsou ${ }^{[\mathrm{a}] *}$ \\ ${ }^{[a]}$ MERLin Group, School of Chemical Engineering, The University of New South Wales, \\ Sydney NSW 2052, Australia. \\ ${ }^{[b]}$ Department of Chemistry and iNANO, Aarhus University, Aarhus 8000 Denmark \\ ${ }^{[c]}$ Department of Imaging and Applied Physics, Curtin University, Bentley WA 6102, \\ Australia \\ ${ }^{[\mathrm{d}]}$ CSIRO, Private Bag 10, Clayton South MDC 3169, Australia \\ ${ }^{[\mathrm{e}]}$ Australian Synchrotron, Clayton, VIC 3168, Australia

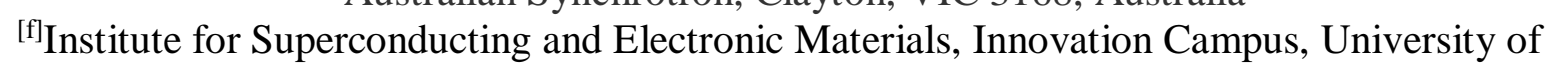 \\ Wollongong, Squires Way, NSW 2500 Australia \\ ${ }^{[\mathrm{g}]}$ Condensed Matter Theory Group, Department of Physics \& Astronomy, \\ Uppsala University, Box 516, 75120 Uppsala, Sweden \\ E-mail: f.aguey@unsw.edu.au, Tel: +61 (0)2 938 57970, Fax: +61 (0)2 93855966
}

\begin{abstract}
One of the limitations to the widespread use of hydrogen as an energy carrier is its storage in a safe and compact form. Herein, recent developments in effective high capacity hydrogen storage materials is reviewed, with a special emphasis on light compounds including those based on organic porous structures, boron, nitrogen and aluminium. These elements and their related compounds hold the promise of high, reversible and practical hydrogen storage capacity for mobile applications including vehicles and portable power equipment, but also for the large scale and distributed storage of energy for stationary applications. Current understanding of the fundamental principles governing the interaction of hydrogen with these light compounds is summarised as well as basic strategies to meet practical targets of hydrogen uptake and release. The limitation of these strategies and current understanding is also discussed and new directions proposed.
\end{abstract}




\section{Contents}

1. Introduction

2. General principles underlying the hydrogen storage properties of high capacity materials

2.1 Hydrogen interactions with materials

2.2 Thermodynamics and kinetics scenario

2.3 Theoretical modelling for hydrogen storage materials

3. High capacity Physisorption materials

3.1 Enhancing the gravimetric performance of metal organic frameworks

3.2 Enhancing volumetric performance of metal organic frameworks

3.3 Operating conditions that minimize loss of hydrogen

4. High capacity boron containing compounds

4.1. Hydrogen release from borohydrides and reversibility

4.2. Improving the properties of borohydrides: Thermodynamics and kinetics

4.3. Nanoconfined borohydrides

4.4. Amine borane derivatives and hydrolysis

5. High capacity amine based compounds

6. High capacity aluminium containing compounds

7. Emerging applications

7.1 Metal hydride operating parameters for application in concentrating solar thermal power

7.2 Potential metal hydrides for application in concentrating solar thermal power

8. Conclusions and outlook 


\section{Introduction}

Hydrogen is the ultimate fuel leading to clean energy systems if produced from renewable sources. The attraction for hydrogen as a universal energy vector is the flexibility associated with its production and use. Although the idea of running energy systems on hydrogen appeared in 1874 in the Mysterious Island by Jules Verne, the concept of the "hydrogen economy" was introduced in 1923 (Figure 1). However after almost a century, the barriers to such a vision have been the fierce competition of fossil fuel based technologies and the lack of methods to effectively store hydrogen in a compact, safe and cost effective manner to allow sufficient driving range - It should be noted that pure battery based electrified vehicles face a similar issue. ${ }^{[1]}$ Since early work in the 1920 's on hydrogen combustion engines by Erren, ${ }^{[2]}$ the technology has been significantly advanced, ${ }^{[3]}$ while the cost per $\mathrm{kW}$ of fuel cells has drastically decreased from $\$ 275 / \mathrm{kW}$ in 2002 to $\$ 49 / \mathrm{kW}$ in 2011. ${ }^{[4]}$ With the discovery of $\mathrm{LaNi}_{5}{ }^{[5]}$ and $\mathrm{FeTi}_{5}{ }^{[6]}$ in the 1970's significant efforts have been made to develop alloys with a higher hydrogen capacity. ${ }^{[7]}$ However, these materials never reached the gravimetric capacity required for powering a vehicle for $400 \mathrm{~km}$ on a metal hydride alone. It is unlikely that hydrogen is still mainly associated with vehicle applications, because over the past decades research efforts have unveiled a range of new technologies including nickel metal hydride batteries ${ }^{[8]}$ sensors ${ }^{[9]}$ processing methods for bulk materials amorphization, ${ }^{[10]}$ switchable mirrors ${ }^{[11]}$ and more recently new ionic conductors for batteries. ${ }^{[12]}$ The "Holy-grail" remains the discovery of advanced materials for mobile applications and this possibly lies within a combination of light elements known as complex hydrides (Figure 2a). To be competitive, hydrogen-powered vehicles should meet performance and cost levels of vehicles currently powered by gasoline. Hence, depending on the type of combustion, i.e. via a fuel cell or direct, 5 to $13 \mathrm{~kg}$ respectively of hydrogen has to be stored on board a vehicle to allow a driving range of $480 \mathrm{~km}$ without refuelling. 
Furthermore, the hydrogen storage material needs to release and absorb hydrogen under mild conditions of pressures $<100$ bar and temperatures $<100{ }^{\circ} \mathrm{C}$ and this with high cycling life. Another option for powering hydrogen vehicles is off-board regeneration. In this case, the hydrogen storage tank is treated like a cartridge, which is exchanged with a fresh tank when nearly empty. Off-board regeneration alleviates the problems associated with the reversibility of high capacity hydride materials since the "active" hydride can be regenerated via alternative means than its direct reaction with hydrogen and several chemical routes have been developed to this aim. ${ }^{[13]}$ However, off-board regeneration is often considered as a "nogo" ${ }^{[14]}$ approach for vehicles since the recovery of the hydride often involves energy intensive processes. However, this off-board approach may be suitable for portable power equipment. At current state, only a few metal hydrides of relativity low capacity can deliver hydrogen at room temperature in a reversible fashion (Figure 1a). The hydrolysis ${ }^{[15]}$ or low temperature thermolysis of hydrides ${ }^{[16]}$ and regeneration off board could thus be a reasonable alternative.

Among the known metal hydrides, only the hydride of magnesium $\left(\mathrm{MgH}_{2}\right)$, aluminium $\left(\mathrm{AlH}_{3}\right)$ or lithium $(\mathrm{LiH})$ would meet the energy density requirements for vehicle applications (Figure 2a). However, all these light metal hydrides reversible store hydrogen under impractical conditions for vehicles. The pressure to release hydrogen from $\mathrm{LiH}$ is too low $(<1$ bar at $\mathrm{RT}),{ }^{[17]}$ conversely $\mathrm{AlH}_{3}$ requires very high pressures for reversibility $(>7$ kbar), ${ }^{[18]}$ and ways to effectively enable the reversible storage of hydrogen in magnesium near ambient temperatures still remain to be found. ${ }^{[19]}$ Since the 1970 's, complex hydrides have been envisaged for hydrogen storage purposes but hydrolysis has for a long time remained the main route to extract hydrogen from these compounds at room temperature. Usually, complex hydrides release hydrogen at high temperatures and in an irreversible fashion involving multiple reaction steps often thought too difficult to control. However in 1995, the discovery of hydrogen reversibility in sodium aluminium hydride $\left(\mathrm{NaAlH}_{4}\right)$ under 
mild conditions of temperatures and pressures, ${ }^{[20]}$ opened an entirely new era in the search for the "holy grail" material (Figure 1).

Twenty years after this initial finding, this review focuses on the progress made to effectively tailor the properties of high hydrogen capacity materials and potential early market penetrations are discussed. These high capacity materials include metal organic frameworks (MOFs), alanates and alanes, but also a range of "new" compounds including amides and borohydrides (Figure 1 and 2). In particular, special emphasis is given to the strategies developed in an attempt to positively modify the properties of these hydrides toward application targets. Additional details on physical properties of complex hydrides such as their crystalline structure have been summarized elsewhere as well as in excellent previous reviews. $^{[16 a, 21]}$

\section{General principles underlying the hydrogen storage properties of high capacity materials}

\subsection{Hydrogen interactions with materials}

The hydrogen storage ability of materials is strongly related with the way hydrogen can be absorbed/desorbed in a material. The interaction of molecular hydrogen or its absorption in materials can be categorized into three processes (Figure 3); (a) physisorption, (b) chemisorption and (c) quasi-molecular interaction, i.e. Kubas interaction. In physisorption, hydrogen does not dissociate but binds to the surface of the material through van der Waals interactions (Figure 3a). This interaction is very weak with an adsorption enthalpy $\left(\Delta H_{a}\right)$ of $4-10 \mathrm{~kJ} \cdot \mathrm{mol}^{-1} \mathrm{H}_{2}$ and a binding energy in the range of 0.04 to $0.1 \mathrm{eV}$. But in chemisorption, the hydrogen molecule first dissociates into individual atoms. The later migrate into the material and then chemically bind with the material (Figure 3b). This hydride bonding is quite strong, having an enthalpy of formation $\left(\Delta H_{f}\right)$ of $100-200 \mathrm{~kJ} \cdot \mathrm{mol}^{-1} \mathrm{H}_{2}$ and a 
binding energy in the range of $2-4 \mathrm{eV}$. In addition to thermodynamic considerations, the hydrogen ab(de)sorption process has to go through a range of activation barriers (Figure $3 \mathrm{~d}$ ). Molecular dissociation will only occur when the energy supplied (depending on temperature and pressure in the system) is higher than the activation energy barrier $\left(\mathrm{E}_{\mathrm{chem}(\mathrm{H})}\right.$, Figure $\left.3 \mathrm{~d}\right)$ of the system. Then bonding takes place by electron sharing in between dissociated hydrogen atoms and metal atoms on the host surface. At the same time hydrogen atoms start to penetrate to the sub-surface of the host material $\left(\mathrm{E}_{\mathrm{pen}(\mathrm{H})}\right.$, Figure $\left.3 \mathrm{~d}\right)$. These atoms can populate the interstitial sites of the host material through surface diffusion $\left(\mathrm{E}_{\mathrm{diff}(\mathrm{H})}\right.$, Figure 3d). As a consequence, a stable metallic hydride phase is formed if the hydrogen concentration is very high. However, when considering complex hydrides, the hydrogen (ab)desorption process will also depend upon ionic diffusion, and the subsequent growth of the hydride phase through the reaction of various ionic species with hydrogen and thus additional activation barriers have to be considered ( $E_{\text {diff(ion), }} E_{\text {nuc }}$ and $E_{\text {growth, }}$ Figure $\left.3 \mathrm{~d}\right)$. Desorption of hydrogen mainly occurs though the reverse process by breaking the hydrogen bonds, either weak van der Waals or strong chemical bonds.

A third type of possible hydrogen interaction is energetically in between physisorption and chemisorption, where the H-bond in the hydrogen molecule is weakened but not dissociated (Figure 3c). The binding energy of this quasi-molecular interaction is in the range of $0.1-0.8 \mathrm{eV}$ with enthalpies in the range of $20-70 \mathrm{~kJ}^{\mathrm{mol}}{ }^{-1} \mathrm{H}_{2}$. Such types of interactions can be observed in two cases: i) a charge transfer between the bonding orbital of $\mathrm{H}_{2}$ molecules and the unfilled $d$-orbitals of transition-metal atoms and back-transfer from the transition-metal atom to the antibonding orbital of the $\mathrm{H}_{2}$ molecule, and ii) the polarization of $\mathrm{H}_{2}$ molecules by the electric field produced by a positively charged metal ion. The charge transfer and polarization can occur between one metal atom and several hydrogen molecules and can thus be used to enhance the hydrogen storage capacity. ${ }^{[22]}$ Therefore if materials 
could be designed on such principles, high storage capacity at ambient pressure and temperature should be feasible.

\subsection{Thermodynamics and kinetics scenario}

Gravimetric storage density and volumetric storage density are the two primary parameters that will determine the potential of materials for suitable hydrogen storage. These parameters are directly or indirectly correlated to the physical properties of materials including surface area, pore structure and volume, particle size, atomic structure and chemical factors such as the affinity for hydrogen, surface reactivity and bond strength. All can alter the thermodynamics and kinetics of ab(de)sorption.

Surface area, pore structure and volume can influence the physisorption mechanism, which is a surface phenomenon. Since chemisorption is followed by physisorption, having high surface areas is thus a prerequisite for fast hydrogen sorption. Increasing surface area means reducing particle size and/or increasing the porosity so a higher number of sites for $\mathrm{H}_{2}$ interaction with the material are available. Porous hydrogen storage materials with high surface area include porous carbon, ${ }^{[23]}$ carbon nanotubes $(\mathrm{CNT}),{ }^{[24]}$ zeolites, ${ }^{[25]}$ metal organic frameworks (MOFs), ${ }^{[26]}$ and polymers with intrinsic microporosity (PIMs). ${ }^{[27]}$ Züttel et al. reported a correlation between storage and surface area of $\sim 1.5$ wt $\% \mathrm{H}_{2}$ uptake for every $1000 \mathrm{~m}^{2} \cdot \mathrm{g}^{-1}$ at 1 bar $\mathrm{H}_{2}$ pressure. ${ }^{[28]}$ However, higher hydrogen uptakes were observed with some porous carbons ${ }^{[23]}$ and MOFs, ${ }^{[26]}$ for example. Therefore, surface alone does not predicate the storage capacity. According to Nijkamp et al. ${ }^{[29]}$ and Lin et al. ${ }^{[26]}$ the pore geometry and volume also affects the storage. Accordingly, the hydrogen storage capacities of MOFs can be tuned by adjusting the framework component, ${ }^{[30]}$ and some MOFs including MOF-177 have achieved surface areas of more than $5000 \mathrm{~m}^{2} . \mathrm{g}^{-1}$ and a storage capacity of 7.5 wt \%. ${ }^{[31]}$ It is noteworthy, that this type of porous material does not normally undergo 
structural changes during (ab)desorption cycles and has good cyclability. But since physisorption is an exothermic process and bonding is very weak, low temperatures normally at boiling point of liquid nitrogen $\left(-196^{\circ} \mathrm{C}\right)$ - are necessary to effectively physisorb hydrogen. This poses additional technical challenges given the large heat of adsorption $(\sim 12-$ $30 \mathrm{MJ}$ ) that will evolve from $6 \mathrm{~kg}$ of hydrogen stored, for example. ${ }^{[32]}$ The maximum surface area reported for carbon is $3150 \mathrm{~m}^{2} \cdot \mathrm{g}^{-1}$ with a porosity of $1.95 \mathrm{~cm}^{3} \cdot \mathrm{g}^{-1}$ and a storage capacity of $6.7 \mathrm{wt} \%$ at $-196{ }^{\circ} \mathrm{C}$ and 20 bar pressure. ${ }^{[23]}$ Accordingly, current carbon materials cannot fulfil the technical requirements for hydrogen storage on-board vehicles. However, MOFs may meet these requirements if high capacity storage closer to room temperature can be achieved. ${ }^{[33]}$

In chemisorption, strong chemical bonds are involved and therefore, high temperatures are required to break these bonds and release hydrogen. The regeneration of "chemisorbent" materials can be understood using the Pressure Composition Isotherm (PCI) of hydride materials. The ideal PCI plot in Figure 4 shows that hydrogen uptake increases with increasing pressure forming a solid solution of hydrogen in the metal ( $\alpha$-phase), but at the equilibrium plateau pressure $\left(P_{e q}\right)$ denoted as point "A" the metal starts to "lock" hydrogen within its structure and form a hydride ( $\beta$-phase). If the applied pressure is below the plateau, then the stored hydrogen is released, given this is kinetically favourable. Therefore to decompose a hydride which is stable under a certain temperature and pressure, the temperature has to be increased to a level where $P_{e q}$ is more than the system pressure. Furthermore, the plateau pressure is related to the changes in enthalpy $(\Delta H)$ and entropy $(\Delta S)$ according to the Van't Hoff equation (Figure 4b). Accordingly, $T_{\text {des }}=\frac{\Delta H}{\Delta S}$ would correspond to the decomposition of the hydride at atmospheric pressure. This dehydrogenation temperature can be as high as $280^{\circ} \mathrm{C}$ in the case of $\mathrm{MgH}_{2} .^{[19]}$

Since, the entropy corresponding to the transition of hydrogen gas molecules to 
chemisorbed hydrogen in the metal is very similar for most metal-hydrogen systems (i.e. 130 $\mathrm{J} . \mathrm{K}^{-1} \cdot \mathrm{mol}^{-1} \mathrm{H}_{2}$ ), the thermodynamic properties of metal-hydrogen systems are usually characterised by the strength of the metal-hydrogen bond and thus by the enthalpy of the (de)hydriding reaction. Complex hydrides follow the same principles despites the complexity of the hydrogen desorption (absorption) process as compared to metal hydrides with $\Delta H$ as the main indicator of their hydrogen storage properties, i.e. assuming that surface reconstruction and entropy changes in the lattice are negligible. Thermodynamically, the hydrogenation reaction will occur for both metal hydrides and complex hydrides if the Gibbs free energy $(\Delta G, \mathrm{~J})$ is negative. This quantity is related to the enthalpy of formation $(\Delta H, \mathrm{~J})$, temperature $(T, \mathrm{~K})$ and entropy of formation $\left(\Delta S, \mathrm{~J} . \mathrm{K}^{-1}\right)$ by the following equation:

$$
\Delta G=\Delta H-T \Delta S
$$

The enthalpy of formation (or heat of reaction) for the hydrogenation reaction usually has a negative value since heat is released at constant pressure. The entropy, or disorder, of the system is reduced during the hydrogenation reaction since hydrogen is changing from the gas phase to its chemisorbed form. Hence as the temperature decreases, the hydrogenation reaction becomes thermodynamically favoured. As the temperature increases, the Gibbs free energy has a positive value so the reverse reaction, the dehydrogenation, is favourable.

On the other hand, the kinetics of the hydrogenation/dehydrogenation reactions depend on the activation energy barrier $\left(E_{A}, \mathrm{~J}\right)$ and the reaction rate $\left(K_{r}\right.$, which is a function of temperature) correlated by the Arrhenius relationship, as follows: ${ }^{[34]}$

$$
K_{r}(T) \propto e^{\left(-E_{A / k_{B} T}\right)}
$$

where $k_{B}$ is the Boltzmann constant $\left(1.381 \times 10^{-23} \mathrm{~J} . \mathrm{K}^{-1}\right)$

Hence, if $E_{A}$ is high and/or the temperature is low, the reaction will proceed much more slowly. Given the requirement for the hydrogenation and dehydrogenation reactions to occur 
at relatively low temperatures, it is thus important to minimise the activation energy for both the dehydrogenation $\left(\mathrm{E}_{\mathrm{A}}^{\mathrm{des}}\right)$ and hydrogenation $\left(\mathrm{E}_{\mathrm{A}}^{\mathrm{ads}}\right)$ reactions (Figure $5 \mathrm{~b}$ ). These can be reduced by catalysis and/or destabilisation (Figure 5). The challenge is how to destabilise the hydride to promote the dehydrogenation reaction at low temperatures and reduce the activation energy barrier for the hydrogenation reaction simultaneously.

Thermodynamic improvements have been achieved by destabilising complex hydrides (e.g. $\mathrm{H}^{\delta+} / \mathrm{H}^{\delta^{-}}$coupling ${ }^{[35]}$ or partial cation substitution ${ }^{[16 \mathrm{a},}{ }^{36]}$ ) or by stabilising the decomposition products. ${ }^{[36-37]}$ For example, the addition of $\mathrm{MgH}_{2}$ to $\mathrm{LiBH}_{4}$ has been found to stabilise the dehydrogenation products of $\mathrm{LiBH}_{4}$, leading to an overall reduction of enthalpy of $25 \mathrm{~kJ} \cdot \mathrm{mol}^{-1} \mathrm{H}_{2} \cdot{ }^{[38]}$ It is noteworthy that these methods improve the thermodynamics by lowering the overall reaction enthalpy and increasing the disorder of the system, but do not have a deliberate effect on the kinetics of the reaction. ${ }^{[39]}$ Often additional catalysts are required to improve kinetics by lowering the activation energy barriers.

As shown Figure 3, finding a suitable catalyst requires identifying the critical limiting steps and energy barriers. In the case of metal hydrides this may be simplified to finding an appropriate catalyst for hydrogen splitting at the surface of the host material, e.g. at magnesium surfaces. ${ }^{[19]}$ However, in the case of complex hydrides this may be more challenging. In addition to the simplified energy barriers described in Figure 3, complex hydrides often undergo multi-step reaction paths involving polymorphic transformations, melting, mass diffusion and disproportionation upon hydrogen release. ${ }^{[21 \mathrm{a}, 40]}$ An effective way to determine reaction paths is sometimes through the use of isotopic exchange. ${ }^{[41]}$

When considering catalysis at the surface of hydrogen storage materials, it has been suggested that hydrogen spillover can also enhance the hydrogen uptake/release. This phenomenon, commonly observed in heterogeneous catalysis, is associated with the dissociation of $\mathrm{H}_{2}$ molecules on catalytically active sites and subsequent migration to the 
surface of the support that would not otherwise adsorb atomic hydrogen. ${ }^{[42]}$ Different methods for enhancing hydrogen capacity through spillover have been reviewed by Wang and Yang. ${ }^{[43]}$ In particular, using this effect a 0.8 wt \% increase in storage capacity has been reported for MOF-177 at 100 bar. ${ }^{[43]}$

\subsection{Theoretical modelling for hydrogen storage materials}

Given the complexity involved in the (de)hydrogenation of complex hydrides, Density Functional Theory (DFT) ${ }^{[44]}$ has become one of the prominent tools for searching efficient hydrogen storage materials and detailed reviews have been published. ${ }^{[45]}$ The profound understanding of the properties for such materials is always intuitive while detailed knowledge of the electronic structure, hydrogen bonding nature, formation enthalpy, elastic constants and vibrational energies is often required. These can be determined from DFT based electronic structure calculations quite elegantly. The formalism is mainly based on finding the efficient solution of the Kohn-Sham equations, which not only consider the electronic attributions, but also the vibrational and elastic properties.

The in-silico technique of DFT also has a number of issues regarding its correlation with experiments. For example, the exchange correlation functional ${ }^{[46]}$ that has been employed in most of the DFT methodology can be a sensitive factor as far as the formation enthalpy is concerned for the hydrides and the alkaline earth metals. This difference can be more prominent in the case of multicomponent materials. Another bottleneck of DFT methodology is the accuracy of the predicted crystal structures corresponding to the electronic energy values. For example, in the case of lithium imide $\left(\mathrm{Li}_{2} \mathrm{NH}\right)$, different hypothetical crystal structures lead to a similar electronic energy. ${ }^{[4]}$ Since DFT calculations are mostly performed at $0 \mathrm{~K}$, additional Molecular Dynamics ${ }^{[48]}$ calculations are often required to get a more accurate understanding of materials behaviour under experimental 
conditions. However, the desorbing temperature can be predicted as an extension of the DFT calculations. ${ }^{[49]}$ Similarly, the Gibbs free energy can be determined from the adsorption energy extracted from DFT, corrected by the change of Zero Point Energy ( $\triangle \mathrm{ZPE})$ and entropic contribution $(T \Delta S)$. Additional determination of the binding energy will also predict the type of adsorption phenomena, whether physisorption or chemisorption. The stability of the material can then be determined by the phonon dispersion relation derived from DFT methodology. ${ }^{[50]}$ Hence, it is often possible to provide through theoretical modelling an overall picture of hydrogen storage materials, although the computational time required for this may be a common limitation.

\section{High capacity physisorption materials}

As previously discussed, one of the primary application for hydrogen storage research is energy storage in vehicles. The US Department of Energy has assessed physisorbents and found that of the 16 key performance indicators, physisorbents inherently meet 13 of them, and are hence extremely attractive for further investigation (Figure 6). The main challenges remaining are to increase the volumetric and gravimetric capacities, and lower the relative loss of useable hydrogen, i.e. in the cryo-refrigeration system. The hydrogen storage properties of selected MOFs are summarized in Table 1.

Gravimetric storage performances are particularly close to the required performances, but many of these have been achieved at the expense of volumetric performance by employing lightweight constituents to deliver lower density adsorbents. ${ }^{[51]}$ Volumetric capacities remain more challenging. Many reported values are calculated from ideal crystal structures, and in reality a tank will not be packed as efficiently as a single crystal. ${ }^{[52]}$ What 
follows is a summary of achievements with metal organic frameworks. Synthetic aspects and characterization methods have been reviewed by Suh et al. ${ }^{[53]}$

\subsection{Enhancing the gravimetric performance of metal organic frameworks}

The various strategies employed for maximizing the gravimetric uptake of hydrogen are summarized in Figure 7. One strategy for further increasing gravimetric capacity is to replace heavy atoms with lighter atoms within the structure. Sumida et al. ${ }^{[54]}$ replaced the $\mathrm{Zn}^{2+}$ ions within the MOF-177 framework with lighter $\mathrm{Be}^{2+}$ ions. The resulting topology was unexpectedly different to the MOF-177, however the gravimetric uptake at room temperature and 100 bar was higher than any other material at the time. Modelling work later revealed that the beryllium-based rings $\left[\mathrm{Be}_{12}(\mathrm{OH})_{12}\right]^{12+}$ have an optimal shape and size $(\sim 6 \AA)$ for room temperature storage. ${ }^{[55]}$ A comparison of experimental gravimetric data at room temperature with structural features revealed a strong dependence on surface area for MOFs with open metal sites and pore volume for MOFs without open metal sites. ${ }^{[55]}$ Similar correlations have been found as a function of pressure for gravimetric data at cryogenic temperatures where heat of adsorption is important at low pressures $(\sim 0.1$ bar $)$, surface area is important at medium pressures ( 30 bar) and pore volume is important at high pressures ( 100 bar). ${ }^{[56]}$ Alternatively the same structure can be maintained with metal atoms being replaced post-synthetically. For example, Lau et al. showed that $\mathrm{Ti}^{4+}$ ions could substitute into the Zr-based UiO-66 framework, leading to significantly increased gravimetric hydrogen storage capacity. ${ }^{[57]}$

At low pressures, the heat of adsorption is greater in small pores where there is an overlap of potential energy fields, particularly for spherically shaped pores. ${ }^{[58]}$ This effect was investigated by Kowalczyk et al. ${ }^{[59]}$ using simulation techniques for nanotubes with a range of tube diameters, where an optimal diameter of $6.8 \AA$ was found for hydrogen capture. 
Chapman et al. ${ }^{[60]}$ synthesized a family of Prussian Blue analogues $\left[\mathrm{M}_{3}^{\mathrm{II}}\left[\mathrm{Co}^{\mathrm{III}}(\mathrm{CN})_{6}\right]_{2}\left(\mathrm{M}^{\mathrm{II}}=\right.\right.$ $\mathrm{Mn}, \mathrm{Fe}, \mathrm{Co}, \mathrm{Ni}, \mathrm{Cu}, \mathrm{Zn}, \mathrm{Cd})$ comprising of small pores $(\sim 5-10 \AA)$ resulting in isosteric heats of adsorption $\sim 40 \%$ higher than commercially available MOF-5. In addition to small pores, the pore walls are lined with bare metal sites exposed for hydrogen adsorption. There is a direct correlation between the hydrogen uptake at 1 bar and the hydrogen-metal interaction potential using the Universal Force Field (UFF). ${ }^{[61]}$ At higher pressures, metal mass and pore volume are expected to be the dominant factors for enhanced gravimetric uptake. Jia et al. showed that small pores can be arrived at through interpenetration within the framework. ${ }^{[62]}$ This delivered improved gravimetric capacity at low pressures due to their being more sites for adsorption.

Another strategy for enhancing gravimetric uptake involves the doping of light organic frameworks such as Porous Aromatic Frameworks (PAFs). ${ }^{[63]}$ PAFs are inherently lighter than metal-organic frameworks due to their purely organic composition. Organic components unfortunately do not interact strongly with hydrogen. Doping has proven effective, as demonstrated by Konstas et al. ${ }^{[63]}$ where PAF-1 was doped with lithium ions. In this case, the doping causes a reduction in the framework creating local charges as well as a contraction of pore sizes. The key to success is to increase hydrogen-framework interactions without adding too much weight to the system. Lithium along with other light ions are amongst the most promising for maximizing the doping effect. ${ }^{[64]}$

Overall, the hydrogen gravimetric uptake target for vehicular transport is readily achieved at cryogenic temperatures while volumetric targets are yet to be met. Interestingly, Goldsmith et al. ${ }^{[65]}$ discovered an upperbound limit in volumetric uptakes (at about $60 \mathrm{~g} \mathrm{H}_{2} . \mathrm{L}^{-}$ $\left.{ }^{1}\right)$ calculated from the crystal structures available from Cambridge Structural Database and a fundamental model incorporating surface area and pore volume. Hence at current state, MOFs may be better suited to applications requiring no restriction on system volume. 


\subsection{Enhancing the volumetric performance of metal organic frameworks}

MOFs have the ability to achieve high volumetric uptake because of their enormous pore volumes, volumetric surface area and metal sites for strongly attracting hydrogen. ${ }^{[66]}$ Every atom that is added to a framework takes up space and therefore it must attract enough hydrogen to achieve a net benefit in volumetric uptake - volume of hydrogen divided by volume of total system. One potential strategy is thus the impregnation of MOFs with guest particles to create additional surface area for adsorption as well as increasing the heat of adsorption due to pore wall-particle potential energy overlaps. ${ }^{[67]}$ Impregnation enhances volumetric uptake at all pressures until the pores are completely filled with the guest particles. This approach has also proved an effective strategy for enhancing volumetric uptake at room temperature. ${ }^{[64 f]}$ However, gravimetric uptake only benefits from impregnation at low pressures.

Functionalisation can also be used to enhance volumetric capacity, as demonstrated by Colon et al. using magnesium alkoxide groups within MOFs and PAFs. ${ }^{[68]}$ The functional groups are either grafted off the ligands post-synthesis or formed with the ligand before selfassembly. Usually, the structures with the highest void fraction benefit the most from functionalization. Ryan et al. explored the effect of catenation and found that catenation decreases gravimetric uptake at high pressures. ${ }^{[69]}$ Volumetric uptake on the other hand is enhanced but only for structures containing significantly large void fractions, for example IRMOF-1 (0.77 void fraction) lost volumetric capacity while IRMOF-16 (0.93 void fraction) gained volumetric capacity. Meng et al. predicted that a combination of catenation and doping could enhance volumetric uptake but at a loss of gravimetric uptake. ${ }^{[70]}$ The approach has been successfully implemented and indeed doping was shown to enhance volumetric uptake. ${ }^{[63,64 b]}$ 
Volumetric uptake will always be maximized at lower temperatures because of the greater hydrogen density. Hydrogen density can be correlated with pore volume where smaller pores offer an overlap of strong adsorption energies but this is usually associated with a loss in total uptake because of the overall low available pore space $;{ }^{[71]}$ and one strategy is to use a di-tagged MOF post-synthetically as shown by Tshering et al. ${ }^{[72]}$ Ideally, a material with many small pores would be optimal to maximize the hydrogen density as well as increase the number of available pockets. ${ }^{[73]}$ This strategy has been implemented by Richardson et al. for example, through the synthesis of a large range of MOFs with functional groups, open-metal sites and interpenetrated networks. ${ }^{[74]}$ For example, they successfully created triply interpenetrated $\mathrm{Al}^{3+}$ and $\mathrm{Ga}^{3+}$ based MOFs creating a stable hydrogen-bonded material that is likely to achieve high hydrogen uptakes. ${ }^{[75]}$

Another promising strategy for enhancing volumetric uptake is the self-assembly of cubic cages capable of encapsulating large amounts of gas at high densities, demonstrated by Clegg et al. ${ }^{[76]}$ An advantage of this approach is the tunability of cage sizes with the choice of alkyl chains of varying lengths. Furthermore, discrete metallo-supramolecular materials such as nanoballs have arisen as promising candidates for hydrogen storage because of their spherical cavity shapes and open metal sites. Batten and his group have explored metal variation $(\mathrm{Cu}, \mathrm{Zn}, \mathrm{Mn}, \mathrm{Cd}$ and $\mathrm{Fe})$ and stacking architectures with a range of nanoballs. ${ }^{[77]}$ These various strategies are summarized in Figure 8.

\subsection{Operating conditions that minimize loss of hydrogen}

Aside from volumetric performance, the operating temperature is the key remaining challenge precluding optimized application of physisorbents. Physisorbents have their highest sorption capacity at cryogenic temperatures. Maintenance of these temperatures within a storage system can drastically reduce the storage efficiency, as adiabatic expansion of the 
stored hydrogen must be used to maintain the requisite low temperatures. ${ }^{[78]}$ The optimum temperature for adsorption is related to the enthalpy of adsorption. Room temperature operation can be optimized when the enthalpy for adsorption is in the range of $15-25 \mathrm{~kJ} \cdot \mathrm{mol}^{-1}$ $\mathrm{H}_{2} \cdot{ }^{\left[{ }^{[9]}\right.}$ However, in physisorbents, the highest enthalpies for adsorption are in the range of 13 $\mathrm{kJ} \cdot \mathrm{mol}^{-1} \mathrm{H}_{2}{ }^{[80]}$ and drop away significantly as the loading of hydrogen increases.

Szilagyi et al. ${ }^{[81]}$ predicted that room temperature storage capacity can be increased by ensuring a good contact of Pd nanoparticles within MOFs to deliver a chemisorptive type behavior. Majumder et al ${ }^{[82]}$ reported a series of isoreticular MOFs consisting of $\mathrm{Mg}, \mathrm{Fe}, \mathrm{Ni}$ and Co with the perylene tetracarboxylate ligand. The design of frameworks heavily loaded with exposed metal centres, which are useful for inducing enhanced physisorptive behavior through the inducement of dipoles in adsorbed $\mathrm{H}_{2}$ molecules, results in stronger bond formation. Sun et al. showed that the optimization of adsorption enthalpy could be addressed from the other direction, seeking to lower the dissociation enthalpy of chemical hydrides by nano-confinement within MOFs. ${ }^{[83]}$ They found that the interaction of $\mathrm{NaBH}_{4}$ with the $\mathrm{Cu}^{2+}$ ions within HKUST-1 lowered the dehydrogenation temperature by more than $100{ }^{\circ} \mathrm{C}$. Peng et al. further extended this concept to the more stable porous aromatic frameworks (PAFs). ${ }^{[84]}$ Similarly, Kolmann et al. found theoretically that Li-doped frameworks delivered charged locations for enhanced hydrogen physisorption to occur, increasing the enthalpy for adsorption. ${ }^{[85]}$ Whilst many of these structures are difficult to achieve in particularly metalcarboxylate MOFs, due to a lack of chemical stability, recently, Konstas et al. found that reductive lithiation was indeed possible in the carbonaceous analogue PAF-1. ${ }^{[63]}$ This diamondoid ultraporous framework, originally reported by Ben et al. ${ }^{[86]}$ shows huge surface areas $\left(2932 \mathrm{~m}^{2} \cdot \mathrm{g}^{-1}\right)$, albeit with low adsorption enthalpies. This delivered increases in hydrogen enthalpy from 5 to over $9 \mathrm{~kJ} \cdot \mathrm{mol}^{-1} \mathrm{H}_{2} \cdot{ }^{[63]}$ Abid et al. ${ }^{[87]}$ reported the preparation of 
the well-known Zr-based MOF, UiO-66, in nanoparticulate form. They found comparatively high enthalpies of adsorption, with as much as $12 \mathrm{~kJ} \cdot \mathrm{mol}^{-1} \mathrm{H}_{2}$ reported.

Many MOFs also exhibit negative thermal expansion, which may affect the nature of the adsorption interaction with hydrogen as a function of temperature. ${ }^{[88]}$ More advanced strategies may also rely on the use of redox active centres ${ }^{[89]}$ or localised magnets ${ }^{[90]}$ to induce charged locations and in turn enhance polarisation of adsorbed gases and create stronger binding enthalpies.

In summary, there are three key strategies for increasing the enthalpy of hydrogen adsorption within MOFs: developing confined pores, including exposed metal sites, or making composites with hydrogen chemisorbents to modulate their behaviour (Figure 7 and 8). The most attractive is the use of exposed metal sites, as maximizing adsorption enthalpy with this technique does not diminish other performance parameters as markedly. However, it appears that this method will not lead to hydrogen storage materials that can operate at room temperature. Nevertheless, any departure from a requirement for operation at $-196{ }^{\circ} \mathrm{C}$ leads to improvements in system efficiency.

\section{High capacity boron containing compounds}

Boron is one of the lightest elements readily forming hydrides and thus boron hydrides are highly interesting for hydrogen storage purposes. The existence of boron hydrides has been known for a long time but most boranes are unstable, volatile and/or toxic (Table 2). The first boron hydride correctly identified was tetraborane $\left(\mathrm{B}_{4} \mathrm{H}_{10}\right)$ in 1912. ${ }^{\text {[91] }}$ The simplest monomer $\mathrm{BH}_{3}$ is a strong Lewis acid that achieves electronic saturation by dimerization into diborane $\left(\mathrm{B}_{2} \mathrm{H}_{6}\right)$ with a hydrogen content of 21.7 wt \%. However, $\mathrm{B}_{2} \mathrm{H}_{6}$ is a 
volatile, toxic and explosive gas. Accordingly, the direct use of boron hydrides for hydrogen storage purposes is not practical.

One of the significant reactions of diborane is its interaction with highly active metals including alkali (e.g. Li, $\mathrm{Na}$, and $\mathrm{K}$ ) and alkaline earth metals (e.g. $\mathrm{Be}, \mathrm{Mg}$ and $\mathrm{Ca}$ ) leading to many non-volatile complex hydrides more suitable for hydrogen storage purposes. Some conventional synthesis routes of selected metal borohydrides of potential interest for hydrogen storage and their hydrogen properties are summarized in Table 3 . The first synthesis of pure alkali borohydride was done by Schlesinger and Brown who reported in 1940 the synthesis of $\mathrm{LiBH}_{4}$ from ethyllithium and diborane. ${ }^{[92]}$ However, high purity $\mathrm{LiBH}_{4}$ can also be obtained by the direct reaction of $\mathrm{LiH}$ with diborane (Table 3). $\mathrm{NaBH}_{4}$ can be prepared by a similarly approach; however, the first convenient method involved the reaction of sodium hydride with sodium trimethoxyhydroborate (Table 3). ${ }^{[93]}$ The direct reaction of hydrogen with sodium using a boron halide as a source of boron has also been reported to lead to $\mathrm{NaBH}_{4}$ but with low purity $(<75 \%) .{ }^{[94]}$ Similarly, the formation of $\mathrm{LiBH}_{4}$ from $\mathrm{LiH}$ and boron is possible to some extent at temperatures above $600{ }^{\circ} \mathrm{C}$ and with hydrogen pressure in excess of 350 bar. $^{[95]}$

Starting from $\mathrm{NaBH}_{4}$ or $\mathrm{LiBH}_{4}$, a relatively simple route to synthesize other metal borohydrides is through a metathesis approach involving the corresponding metal chloride according to reaction $(3)$ :

$$
\mathrm{MCl}+\mathrm{LiBH}_{4} \rightarrow \mathrm{MBH}_{4}+\mathrm{LiCl}
$$

This synthesis can be carried out in a solvent or under dry conditions by mechanical milling (Table 3). ${ }^{[96]}$ The later has been widely employed to prepare mixed borohydrides through partial cation substitution (Table 4). ${ }^{[97]}$ Although the method is very attractive due to its convenience, it has several drawbacks including the difficulty to control the milling process and thus associated side reactions, and the problem of purification of the final borohydride 
compound. Hence, upon the metathesis reaction (3) the removal of the chloride by-product which usually constitutes a "dead mass" of 40-60 wt \% for hydrogen storage purposes is often difficult. Furthermore, the heat involved in the milling process can sometimes induce a partial halide substitution in the borohydride synthesized and several competing reaction paths. For example, ball-milling $\mathrm{ZnCl}_{2}$ and $\mathrm{KBH}_{4}$ leads to the formation of $\mathrm{KZn}\left(\mathrm{BH}_{4}\right) \mathrm{Cl}_{2}{ }^{[98]}$ whereas small variations of $\mathrm{ZnCl}_{2}: \mathrm{NaBH}_{4}$ ratio may lead to various mix borohydrides including $\mathrm{NaZn}\left(\mathrm{BH}_{4}\right)_{3}$ and $\mathrm{NaZn}_{2}\left(\mathrm{BH}_{4}\right)_{5} \cdot{ }^{[99]}$ Several borohydrides including magnesium, ${ }^{[100]}$ sodium $^{[101]}$ and calcium ${ }^{[102]}$ have also been found to undergo partial halide substitution upon thermal decomposition and hydrogen release or phase transition. ${ }^{[102]}$ However, halidesubstituted borohydrides are often more stable than their pristine counter-parts and thus higher temperatures are required for hydrogen desorption. ${ }^{[102]}$ Solvent purification is possible but it often leads to ether-solvated products difficult to purify without a partial or complete thermal decomposition of the borohydride. Recent synthesis approaches using dimethylsulfide (DMS) have proven more promising in producing pure borohydrides. ${ }^{[103]}$ The direct synthesis of mixed borohydrides from individual borohydrides although severely limited by the thermodynamic of the reaction may also be an alternative in particular cases. Hence, a few mixed borohydrides such as $\mathrm{NaK}\left(\mathrm{BH}_{4}\right)_{2},{ }^{[104]} \mathrm{K}\left[\mathrm{Al}\left(\mathrm{BH}_{4}\right)_{4}\right],{ }^{[105]} \mathrm{LiK}\left(\mathrm{BH}_{4}\right)_{2}{ }^{[106]}$ have been directly synthesized from their corresponding borohydrides but with a limited purity. Recently, Jarón et al. proposed an alternative route based on a modified metathesis route. ${ }^{[107]}$

Among the various known borohydrides, $\mathrm{LiBH}_{4}, \mathrm{Mg}\left(\mathrm{BH}_{4}\right)_{2}$ and $\mathrm{Ca}\left(\mathrm{BH}_{4}\right)_{2}$ have been the focus of many efforts due to their high hydrogen capacity and proven partial reversibility. ${ }^{[108]}$ Efforts with $\mathrm{NaBH}_{4}$ have often focused on hydrogen extraction through hydrolysis most likely for historical reasons, with the demonstration of $\mathrm{NaBH}_{4}$ stability in 
alkaline media and controlled hydrogen generation with appropriate catalysts as early as $1953 \cdot{ }^{[109]}$

\subsection{Hydrogen release from borohydrides and reversibility}

The overall dehydrogenation of alkali metal borohydrides such as $\mathrm{LiBH}_{4}$ and $\mathrm{NaBH}_{4}$ is often simplified as: ${ }^{[21 \mathrm{a}]}$

$$
\mathrm{M}\left(\mathrm{BH}_{4}\right) \rightarrow \mathrm{MH}+\mathrm{B}+3 / 2 \mathrm{H}_{2}
$$

For alkaline earth borohydrides the dehydrogenation route may follow the reactions paths (5a), e.g. for $\mathrm{Mg}\left(\mathrm{BH}_{4}\right)_{2}{ }^{[110]}$ or (5b), e.g. for $\mathrm{Ca}\left(\mathrm{BH}_{4}\right)_{2}$ : ${ }^{[110]}$

$$
\begin{aligned}
& \mathrm{M}\left(\mathrm{BH}_{4}\right)_{2} \rightarrow \mathrm{MH}_{2}+2 \mathrm{~B}+3 \mathrm{H}_{2} \\
& \mathrm{M}\left(\mathrm{BH}_{4}\right)_{2} \rightarrow 2 / 3 \mathrm{MH}_{2}+1 / 3 \mathrm{MB}_{6}+10 / 3 \mathrm{H}_{2}
\end{aligned}
$$

Some borohydrides may also decompose by liberating a significant amount of diborane such as $\mathrm{Zn}\left(\mathrm{BH}_{4}\right)_{2}$ following reaction (6). ${ }^{[111]}$

$$
\mathrm{Zn}\left(\mathrm{BH}_{4}\right)_{2} \rightarrow \mathrm{Zn}+\mathrm{B}_{2} \mathrm{H}_{6}+\mathrm{H}_{2}
$$

This range of possible decomposition paths reflects the difficulty in tailoring the hydrogen storage properties of borohydrides for hydrogen storage application since the improvements achieved with one material may not be applicable to other borohydrides. Furthermore, these simplified dehydrogenation steps often hide multistep decomposition paths, various polymorphs, e.g. $\alpha, \beta$ and $\gamma-\mathrm{Ca}\left(\mathrm{BH}_{4}\right)_{2},{ }^{[12]}$ and side reactions. One of the most studied borohydrides, i.e. $\mathrm{LiBH}_{4}$, exhibits four endothermic peaks during decomposition (Figure 9a). $\mathrm{LiBH}_{4}$ undergoes a first phase transformation, from orthorhombic to hexagonal at around 120 ${ }^{\circ} \mathrm{C}$. This is them followed by the melting at around $290{ }^{\circ} \mathrm{C}$ and decomposition into B and $\mathrm{LiH}$ at around $500{ }^{\circ} \mathrm{C}$. At higher temperatures more hydrogen can be extracted from the decomposition of $\mathrm{LiH}$ leading to a theoretical release of 18.4 wt $\%$ of hydrogen. This decomposition may also include additional intermediate products and in particular various 
$\mathrm{Li}_{2} \mathrm{~B}_{12} \mathrm{H}_{12}$ phases depending upon the conditions of reaction including the hydrogen backpressure. Previous investigations proposed the formation of crystalline $\mathrm{Li}_{2} \mathrm{~B}_{12} \mathrm{H}_{12}(\mathrm{~Pa}-3$ structure type) upon $\mathrm{LiBH}_{4}$ melting and further reaction with $\mathrm{B}_{2} \mathrm{H}_{6}$ (Figure 9b). However, in a recent investigation a new $\gamma-\mathrm{Li}_{2} \mathrm{~B}_{12} \mathrm{H}_{12}$ polymorph and associated $\mathrm{H}$-poor $\mathrm{Li}_{2} \mathrm{~B}_{12} \mathrm{H}_{12-\mathrm{x}}$ intermediates were observed instead. ${ }^{[13]}$ This would suggest a more complex decomposition mechanism for $\mathrm{LiBH}_{4}$ than previously described (Figure 9b) as suggested by Pitt et al. (reactions $7 \mathrm{a}-\mathrm{c}) .{ }^{[113]}$ In this proposed reaction path the formation of amorphous a- $\mathrm{B}_{1-\mathrm{x}} \mathrm{Li}_{\mathrm{x}}$ has also been assumed.

$$
\begin{aligned}
& 12 \mathrm{LiBH}_{4} \rightarrow \gamma-\mathrm{Li}_{12} \mathrm{~B}_{12} \mathrm{H}_{12}+10 \mathrm{LiH}+13 \mathrm{H}_{2} \\
& \gamma-\mathrm{Li}_{12} \mathrm{~B}_{12} \mathrm{H}_{12}+10 \mathrm{LiH} \rightarrow \mathrm{Li}_{12} \mathrm{~B}_{12} \mathrm{H}_{12-\mathrm{x}}+10 \mathrm{LiH}+\mathrm{x} / 2 \mathrm{H}_{2} \\
& \mathrm{Li}_{12} \mathrm{~B}_{12} \mathrm{H}_{12-\mathrm{x}}+10 \mathrm{LiH} \rightarrow(12) \mathrm{a}-\mathrm{BLi}(\mathrm{y}+2) / 12 \\
&
\end{aligned}
$$

In addition to the exact reaction mechanisms, the thermodynamic properties of borohydrides are to a large extent unknown. Experientially, thermodynamic values are determined by PCI which implies the sole release of hydrogen and relativity fast kinetics so that equilibrium can be reached. However, borohydrides often involve a partial evaporation of elements, e.g. in the form of $\mathrm{B}_{2} \mathrm{H}_{6}$ and even metal evaporation, e.g. $\mathrm{Na}$ during $\mathrm{NaBH}_{4}$ decomposition, ${ }^{[14]}$ and very slow kinetics. Hence, reported values of enthalpy and entropy of the decomposition reaction of borohydrides may be subject to discussion, while PCI absorption measurements are often out of reach due to the irreversibility of borohydrides. This is reflected by the discrepancies of the thermodynamic values reported (Table 3). Hence thermodynamic values varying from 56 to $75 \mathrm{~kJ} \cdot \mathrm{mol}^{-1} \mathrm{H}_{2}$ have been reported for $\mathrm{LiBH}_{4}$. An additional difficulty with borohydrides is the need to control both enthalpic and entropic evolutions, because it is unlikely that entropic evolutions along the various hydrogen release paths will be related to the standard entropy of hydrogen only, i.e. 130 J.K.mol ${ }^{-1} \mathrm{H}_{2}$, 
The complexity of the decomposition mechanism of $\mathrm{LiBH}_{4}$ described above is also valid for other borohydrides. For example, eight distinct steps have been observed for the decomposition of $\mathrm{Mg}\left(\mathrm{BH}_{4}\right)_{2}$ by in-situ diffraction including two polymorphic transitions before melting. ${ }^{[15]} \mathrm{Mg}\left(\mathrm{B}_{3} \mathrm{H}_{8}\right)_{2}$ has also been proposed as an intermediate during the thermal decomposition of $\mathrm{Mg}\left(\mathrm{BH}_{4}\right)_{2}$ at $200{ }^{\circ} \mathrm{C}$ in vacuum. ${ }^{[16]}$

As summarized in Table 3, all borohydrides of high hydrogen storage capacity often involve high temperatures for hydrogen desorption and "irreversibility" most likely due to the extensive elemental disproportionation during hydrogen release and the high energy required for elemental recombination. Starting from $\mathrm{LiH}$ and $\mathrm{B}, \mathrm{LiBH}_{4}$ can be regenerated to some extent under 350 bar hydrogen pressure at $500{ }^{\circ} \mathrm{C},{ }^{[95 a]}$ or at a lower hydrogen pressure of 150 bar at $727{ }^{\circ} \mathrm{C} .{ }^{[95 b]}$ Using binary compounds such as $\mathrm{LiB}_{\mathrm{x}}$ to facilitate the recombination of $\mathrm{Li}$ and $\mathrm{B}$ has been shown to improve the rehydrogenation kinetics. ${ }^{[17]}$ For $\mathrm{NaBH}_{4}$, reversibility can also be achieved to some extent by applying 173 bar hydrogen pressure at $400{ }^{\circ} \mathrm{C}$ to a stoichiometric mixture of $\mathrm{NaH}$ and $\mathrm{B}$ for $24 \mathrm{~h}$ (Figure 10). Direct rehydrogenation of $\mathrm{Mg}\left(\mathrm{BH}_{4}\right)_{2}$ from $\mathrm{Mg}$ and $\mathrm{B}$ however leads to the formation of $\mathrm{MgB}_{12} \mathrm{H}_{12}$ and this can be understood by the difficulty of breaking the B-B bonds in the icosahedral cluster of B to from $\left(\mathrm{BH}_{4}\right)^{-[118]}$ However, starting from $\mathrm{MgB}_{2}, \mathrm{Mg}\left(\mathrm{BH}_{4}\right)_{2}$ can be obtained after a few days under a hydrogen pressure of 900 bar at $400{ }^{\circ} \mathrm{C} .{ }^{[119]}$ It is noteworthy, that such re(de)hydrogenation conditions are not ideal. In addition to the high temperatures and pressures, the material will undergo morphological evolutions through repeated melting/re-solidification detrimental to the hydrogen properties. ${ }^{[119 a]}$

\subsection{Improving the properties of borohydrides: Thermodynamics and kinetics}

Improving the thermodynamics of borohydrides has mainly focused on a stabilization or destabilization approach (Figure 5a). The strategy is similar to that applied to metal 
hydrides and an archetypical example is the alloying of $\mathrm{MgH}_{2}$, a stable hydride, with $\mathrm{Ni}$, forming non stable hydride, to lead to a $17 \%$ decrease in the enthalpy of the magnesium/hydrogen reaction through the formation of $\mathrm{Mg}_{2} \mathrm{NiH}_{4}{ }^{[19]}$ Examples of such a concept applied to borohydrides are summarized in Table 5. One of the early examples of the potential of the approach was through the combination of $\mathrm{LiBH}_{4}$ and $\mathrm{MgH}_{2}$, where magnesium was used to stabilize the dehydrogenated state of the borohydride following (8).

$$
2 \mathrm{LiBH}_{4}+\mathrm{MgH}_{2} \rightarrow 2 \mathrm{LiH}+\mathrm{MgB}_{2}+4 \mathrm{H}_{2}
$$

In this case, due to the formation of $\mathrm{MgB}_{2}$, the enthalpy of reaction was reduced to 45.8 $\mathrm{kJ} \cdot \mathrm{mol}^{-1} \mathrm{H}_{2}$ with a potential desorption temperature of $225^{\circ} \mathrm{C}$ at a hydrogen equilibrium pressure of 1 bar. ${ }^{[38]}$ However, the control of such a reaction remains complicated because its path depends upon the experimental conditions. Hence, under dynamic vacuum the following path has been observed (9a and $b):^{[120]}$

$$
\begin{gathered}
0.3 \mathrm{LiBH}_{4}+\mathrm{MgH}_{2} \rightarrow 0.3 \mathrm{LiBH}_{4}+\mathrm{Mg}+\mathrm{H}_{2} \\
0.3 \mathrm{LiBH}_{4}+\mathrm{Mg}+\mathrm{H}_{2} \rightarrow 0.78 \mathrm{Mg}_{0.816} \mathrm{Li}_{0.184}+0.52 \mathrm{Mg}_{0.70} \mathrm{Li}_{0.30}+0.3 \mathrm{~B}+1.60 \mathrm{H}_{2}
\end{gathered}
$$

While under a hydrogen back-pressure $\mathrm{MgB}_{2}$ is formed following the two steps reaction mechanism (10a and $b)^{[121]}$

$$
\begin{aligned}
& 2 \mathrm{LiBH}_{4}+\mathrm{MgH}_{2} \rightarrow 2 \mathrm{LiBH}_{4}+\mathrm{Mg}+\mathrm{H}_{2} \\
& 2 \mathrm{LiBH}_{4}+\mathrm{Mg}+\mathrm{H}_{2} \rightarrow 2 \mathrm{LiH}+\mathrm{MgB}_{2}+4 \mathrm{H}_{2}
\end{aligned}
$$

Furthermore, the hydrogen kinetics remain relatively slow even at $400{ }^{\circ} \mathrm{C}$ with full desorption taking up to $24 \mathrm{~h}$ under hydrogen back-pressure. ${ }^{[122]}$

Due to the observation of such stabilisation effects, other combinations have been investigated through the mixing of $\mathrm{LiBH}_{4}$ with other metal hydrides, ${ }^{[123]} \mathrm{LiNH}_{2},{ }^{[124]}$ or a combination of $\mathrm{MgH}_{2}$ and $\mathrm{LiAlH}_{4},{ }^{[125]}$ for example. However, to date these mixtures of hydrides still require high temperatures to enable reversibility (Table 5). A similar concept has also been applied to other borohydrides (Table 5). In particular, coupling $\mathrm{NaBH}_{4}$ and 
$\mathrm{MgH}_{2}$ led to the formation of $\mathrm{MgB}_{2}$, which helped stabilised the dehydrogenated product. However, the de(re)hydrogenation paths were found to be highly dependent upon the experimental conditions and in particular the applied pressure. During desorption, the decomposition would follow the path $(11 \mathrm{a}-\mathrm{c}) ;{ }^{[126]}$ however, if the release of hydrogen is carried out under vacuum the end product may include $\mathrm{Na}, \mathrm{B}$ and $\mathrm{Mg} .{ }^{[127]}$

$$
\begin{aligned}
& 2 \mathrm{NaBH}_{4}+\mathrm{MgH}_{2} \rightarrow \mathrm{Mg}+\mathrm{H}_{2}+2 \mathrm{NaBH}_{4} \\
& \mathrm{Mg}+\mathrm{H}_{2}+2 \mathrm{NaBH}_{4} \rightarrow 1 / 6 \mathrm{Na}_{2} \mathrm{~B}_{12} \mathrm{H}_{12}+5 / 3 \mathrm{NaH}+\mathrm{Mg}+19 / 6 \mathrm{H}_{2} \\
& 1 / 6 \mathrm{Na}_{2} \mathrm{~B}_{12} \mathrm{H}_{12}+5 / 3 \mathrm{NaH}+\mathrm{Mg}+19 / 6 \mathrm{H}_{2} \rightarrow 2 \mathrm{NaH}+\mathrm{MgB}_{2}+4 \mathrm{H}_{2}
\end{aligned}
$$

Rehydrogenation of a $2 \mathrm{NaH} / \mathrm{MgB}_{2}$ mixture will also lead to a partially rehydrogenated material depending on the applied pressure. Hence, at 25 bar a mixture of $\mathrm{MgB}_{2}, \mathrm{Mg}$ in a $\mathrm{NaH}-\mathrm{NaBH}_{4}$ molten phase was obtained, whereas at a higher pressure of 50 bar the $\mathrm{NaBH}_{4}$ phase was formed in a more significant amount. ${ }^{[128]}$

Destabilization is the other approach widely investigated, since a correlation was found between the enthalpy change of desorption $\left(\Delta H_{d e s}\right)$ of $\mathrm{M}\left(\mathrm{BH}_{4}\right)$ and the Pauli electronegativity $\chi_{p}$ of borohydride cations. ${ }^{[129]}$ This was confirmed through experimental determination of the decomposition temperature $\left(T_{d}\right)$ of various borohydrides since a good correlation was also found between $T_{d}$ and $\chi_{p}$ (Figure 11). ${ }^{[130]}$ Based on this, several mixed borohydrides have been synthesized with the hope that combining cations of "distant" electronegativity would lead to multi cation borohydrides with an intermediate thermodynamic stability. However, for most of these new compounds the complexity inherent to the decomposition mechanism of borohydrides often limits possible improvement in dehydrogenation and reversibility. For example, bimetallic borohydrides of group I/Sc still lose boron in the form of $\mathrm{B}_{2} \mathrm{H}_{6}$ during hydrogen release which obviously impedes reversibility. ${ }^{[131]}$ Some of these mixed borohydrides are summarized in Table 4 . It is noteworthy, that the correlation of $T_{d}$ as function of the electronegativity $\chi_{p}$ is only an 
indicative trend and some cations, e.g. transition metals, may significantly deviate from that trend (Figure 11). Furthermore, such a correlation assumes that entropic evolutions only correspond to that of the hydrogen absorption/desorption process although borohydrides undergo significant disproportionation during hydrogen release. Vibrational entropies of solid phases can significantly evolve upon structural and compositional modifications, ${ }^{[132]}$ resulting in up to $30 \%$ change in $\Delta S .^{[133]}$ While a theoretical model would be extremely valuable to design borohydride based materials, the current lack of broad fundamental understanding remains a significant limitation.

The well-known destabilisation approach through the combination of $\mathrm{H}^{\delta+}$ and $\mathrm{H}^{\delta-}$ used to tailor the properties of metal amides ${ }^{[21 \mathrm{~d}]}$ is another path that has been explored. Since borohydrides readily from compounds with ammonia, ${ }^{[94]}$ the combination of $\mathrm{H}^{\delta-}$ (from $\mathrm{BH}_{4}{ }^{-}$) and $\mathrm{H}^{\delta+}$ (from $\mathrm{NH}_{3}$ ) should lead to higher storage capacity and lower temperatures for hydrogen release (Table 6). Example of such compounds are $\mathrm{Zn}\left(\mathrm{BH}_{4}\right)_{2} \cdot 2 \mathrm{NH}_{3},{ }^{[134]}$ and $\mathrm{Al}\left(\mathrm{BH}_{4}\right)_{3} \cdot 6 \mathrm{NH}_{3} \cdot{ }^{[135]} \mathrm{Zn}\left(\mathrm{BH}_{4}\right)_{2} \cdot 2 \mathrm{NH}_{3}$ can be simply synthesized by ball-milling a mixture of $\mathrm{ZnCl}_{2} \cdot 2 \mathrm{NH}_{3}$ and $2 \mathrm{LiBH}_{4}$. This compound has a monoclinic unit cell in which $\mathrm{Zn}$ atoms coordinate with two $\mathrm{BH}_{4}$ and two $\mathrm{NH}_{3}$ groups leading to a shorter $\mathrm{Zn}-\mathrm{H}$ bond, a increase in the ionic character of $\mathrm{H}$ and thus enhanced dehydrogenation behaviours. Indeed, 8.9 wt \% hydrogen is released from $\mathrm{Zn}\left(\mathrm{BH}_{4}\right)_{2} \cdot 2 \mathrm{NH}_{3}$ below $115{ }^{\circ} \mathrm{C}$ within 10 min. Furthermore, through the combination of such ammine borohydride compounds with other metal hydrides, significant amounts of hydrogen can be extracted with high purity and at low temperatures. For example, the combination of $0.5 \mathrm{Mg}\left(\mathrm{BH}_{4}\right)_{2}$ with $\mathrm{Li}_{2} \mathrm{Al}\left(\mathrm{BH}_{4}\right)_{5} \cdot 6 \mathrm{NH}_{3}$ released more than 10 wt \% high purity $\mathrm{H}_{2}(>99.9 \%)$ within 30 min and below $120{ }^{\circ} \mathrm{C} .{ }^{[135]}$ The release of hydrogen is not reversible. Nonetheless, this demonstrates the potential of combining various hydrides. 
Improving the hydrogen kinetics of borohydrides is another issue and to date no catalyst is known. Often various additives, such as halides and oxides have been wrongly termed catalysts because of some improvement of kinetics (Table 5). As an example, the kinetics of $\mathrm{NaBH}_{4}$ were significantly enhanced with $\mathrm{TiF}_{3}$ doping as compared to $\mathrm{Ti}$ or $\mathrm{TiH}_{2}$ additives (Figure 12). ${ }^{[136]}$ However, all these additives readily react with borohydrides through the well-known metathesis route (reaction 3) and thus the effect observed are most likely due to an enhanced decomposition triggered by the exothermic reaction (3) and/or an effective dispersion of the borohydride phase leading to small particles easier to (de)rehydrogenate due to shorter diffusion paths. This misconception may come from the previous achievements with Ti-doped $\mathrm{NaAlH}_{4}$ and the remarkable reversibility achieved under mild conditions for this system. ${ }^{[20]}$ However in Ti-doped $\mathrm{NaAlH}_{4}{ }^{[137]}$ (and more generally transition metal doped $\left.\mathrm{NaAlH}_{4}\right)^{[138]}$ the catalytically active species is not consumed during the hydrogenation and dehydrogenation steps, ${ }^{[139]}$ meaning that long-term hydrogen cycling can be performed under modest conditions. ${ }^{[140]}$

The mechanism for hydrogen diffusion in borohydrides is believed to occur through a direct exchange between $\mathrm{BH}_{4}$ units at a relatively slow rate and then transport through the ionic crystal by intact $\mathrm{BH}_{4}{ }^{-}$units, ${ }^{[141]}$ and such a diffusion would be facilitated more readily in the molten state. The self-diffusion constant of deuterium in $\mathrm{LiBH}_{4}$ is estimated to be around 7. $10^{-14} \mathrm{~m}^{2} \cdot \mathrm{s}^{-1}$ at $200{ }^{\circ} \mathrm{C} \cdot{ }^{[141]}$ Furthermore, the fast diffusion of lithium observed in the high temperature phase of $\mathrm{LiBH}_{4}$, i.e. $\mathrm{P} 63 \mathrm{mc},{ }^{[142]}$ has led to the application of $\mathrm{LiBH}_{4}$ as an electrolyte for Li-ion batteries. ${ }^{[12]}$ Considering the few routes known so far for the direct rehydrogenation (Figure 9), i.e. the $\mathrm{LiH}$ with $\mathrm{B}_{2} \mathrm{H}_{6}$ reaction and the $\mathrm{LiH}$ with $\mathrm{B}$ reaction promoted by metal boron compounds such as $\operatorname{LiB}_{x},{ }^{[117]}$ and the significant disproportionation involved in the decomposition of borohydrides, effective catalysts are required not only to 
promote ionic transport at low temperatures but also the effective dissociation of hydrogen in an adequate form, i.e. $\mathrm{H}^{-}, \mathrm{H}^{+}$or $\mathrm{H}$, for absorption and recombination for desorption.

\subsection{Nanoconfined borohydrides}

As discussed above, hydrogen uptake and release from borohydrides is severely limited by the need for high temperatures to enable ionic diffusion, recombination of stable dehydrogenation products and the multistep decomposition paths often segregating elements essential for full reversibility. A potential approach to overcome both kinetic and thermodynamic issues is through the reduction of particle size to the nanometer range and confinement of such nanoparticles within a closed shell to allow the sole escape of hydrogen. At the nanoscale many materials are known to undergo significant alternation of properties. An archetypical example is gold, which changes from an inert material into a red colored highly catalytic active material once reduced below $20 \mathrm{~nm} .^{[143]}$

Early investigations into nanoscale hydrides where triggered around 2005 by a range of indicators proving the potential of the approach (Figure 1). These include theoretical calculations mainly focused on $\mathrm{MgH}_{2}$ and predicting a decrease in enthalpy for particle sizes below 2-5 nm. ${ }^{[144]}$ Experimental characterization of $\mathrm{Pd}-\mathrm{H}$ also revealed significant thermodynamic shifts, i.e. a decrease of both enthalpy and entropy, upon particle size reduction. ${ }^{[145]} \mathrm{NH}_{3} \mathrm{BH}_{3}$ confined within the porosity of SBA-15 also showed high purity hydrogen desorption at lower temperatures. ${ }^{[146]}$ The approach would thus have the potential not only to improve hydrogen kinetics but also lead to easier thermodynamic paths. ${ }^{[19,147]}$ Examples of possible improvements through the approach are summarized in Table 7.

To date, most nanoconfinement of complex hydrides has been done through the use of porous inorganic hosts and in particular porous carbons. ${ }^{[148]}$ The porous support can be loaded through melt infiltration or solution impregnation whereby a saturated solution of 
borohydride is evaporated within the porosity of the carbon. Most investigations have focused on the main high capacity borohydrides including $\mathrm{LiBH}_{4}$ and its combination with $\mathrm{MgH}_{2}$. As first reported by Gross et al. ${ }^{[149]}$ the temperature for hydrogen release from $\mathrm{LiBH}_{4}$ is largely decreased upon nanoconfinement and this improvement may be related to the increased ionic mobility at the nanoscale. ${ }^{[150]}$ Upon nanoconfinement, no $\mathrm{B}_{2} \mathrm{H}_{6}$ is released from $\mathrm{LiBH}_{4}$ and this may be due to a modification of the decomposition path or a faster reaction within the tight porosity of $\mathrm{B}_{2} \mathrm{H}_{6}$ with $\mathrm{LiBH}_{4}$ forcing the decomposition mechanism through the $\mathrm{Li}_{2} \mathrm{~B}_{12} \mathrm{H}_{12}$ route. Indeed, the significant amounts of $\mathrm{Li}_{2} \mathrm{~B}_{12} \mathrm{H}_{12}$ observed within confined $\mathrm{LiBH}_{4}$ would support such a mechanism. ${ }^{[151]}$ Similarly nanoconfinement of $\mathrm{LiBH}_{4}+$ $\mathrm{MgH}_{2}$ led to lower desorption temperatures but with decreasing hydrogen cycling capacities. ${ }^{[151 b]}$

Often a reaction between the confined borohydride and the host material can be expected. This is not only true for ordered mesoporous materials such as SBA-15 silicas which carry a significant amount of oxygen surface groups easily reactive toward strong reducing agents such as borohydrides but also for porous carbons. ${ }^{[152]}$ Interaction of borohydrides with host carbons can lead to the intercalation of borohydride cations, e.g. Li and $\mathrm{Na}$, with beneficial ${ }^{[153]}$ or detrimental effects upon extensive $\mathrm{Li}$ intercalation, for example. ${ }^{[151 \mathrm{a}]}$ Furthermore, the many oxygen groups at the surface of carbons can lead to a significant degradation of confined borohydrides and consecutive capacity lost and leaching of borohydrides outside the porosity. ${ }^{[154]}$ This is readily apparent with $\mathrm{LiBH}_{4}$ confined within carbon nanotubes showing a decrease in cyclability as the borohydride is leaching-out of the carbon nanotubes (Figure 13a, b, and c). ${ }^{[154]}$ House et al. indeed confirmed that $\mathrm{LiBH}_{4}$ incorporated in nanoporous carbon was ejected as $\mathrm{LiH}$ during hydrogen release at $200{ }^{\circ} \mathrm{C}$, i.e. after melting, ${ }^{[155]}$ and a similar phenomenon is observed in nanoconfined $\mathrm{NaAlH}_{4}$, with the extraction of $\mathrm{Al} .{ }^{[156]}$ Obviously this is a severe limitation, although the approach is a very 
effective way to determine the properties of borohydrides at the nanoscale. Another issue is the low storage capacity of these confined hydride materials (often $<15 \%$ of the theoretical capacity) due to the inherent difficulty of filling the porosity. To overcome these limitations a core-shell approach has recently been introduced. ${ }^{[114,157]}$ As borohydrides undergo melting and partial elemental evaporation during hydrogen release, nanosized particles of borohydrides should be fully confined individually within a shell only permeable to hydrogen. The method allowed for the first time stable high reversible capacity with nanosized $\mathrm{NaBH}_{4}$ (Figure $13 \mathrm{~d}$ and e). ${ }^{[14,157]}$

Other hosts such as MOFs would also be an interesting alternative assuming that the reactivity of the ligands holding the MOF structure can be tailored to resist the strong reducing ability of borohydrides. Hybrid MOF/borohydride systems could then provide the ability to store hydrogen in a physisorbed and chemisorbed manner. Early progress in that direction have been made with the report of $\mathrm{LiBH}_{4}$ nanoconfined within $\mathrm{Cu}-\mathrm{MOFs} .{ }^{[83]}$

\subsection{Amine borane derivatives and hydrolysis}

As previously discussed, another strategy to extract hydrogen from borohydrides is through the direct combination of $\mathrm{BH}_{3}$ with ammonia leading to amino borane compounds containing hydrogen in hydridic $\left(\mathrm{H}^{\delta-}\right)$ and protonic $\left(\mathrm{H}^{\delta+}\right)$ form such as $\mathrm{NH}_{3} \mathrm{BH}_{3 .}{ }^{[158]} \mathrm{Hydrogen}$ can then be generated by a) the hydrolysis of amine borane with protonic hydrogen $\left(\mathrm{H}^{\delta+}\right)$ from $\mathrm{H}_{2} \mathrm{O}$, or b) a thermolysis route leading to the intermolecular or intramolecular recombination of $\mathrm{H}^{\delta-}$ and $\mathrm{H}^{\delta+}$ within amine borane. Early investigations on borohydride hydrolysis focused on $\mathrm{NaBH}_{4}$ because as compared to other borohydrides such as $\mathrm{LiBH}_{4}$ or $\mathrm{KBH}_{4}$ it is stable under alkaline conditions and its hydrogen evolution (reaction 12) can be controlled with appropriate catalysts showing decreasing effectiveness in the following order $\mathrm{Ru}>\mathrm{Rh}>\mathrm{Pt}>\mathrm{Co}>\mathrm{Ni}>\mathrm{Os}>\mathrm{Ir}>\mathrm{Fe}>>\mathrm{Pd}^{[159]}$ 


$$
\mathrm{NaBH}_{4}+4 \mathrm{H}_{2} \mathrm{O} \rightarrow \mathrm{NaBO}_{2} \cdot 2 \mathrm{H}_{2} \mathrm{O}+4 \mathrm{H}_{2}
$$

However, the use of $\mathrm{NaBH}_{4}$ as a hydrogen store though hydrolysis faces several issues related to the low net storage capacity, catalyst durability and/or poisoning, and effective routes for regeneration. ${ }^{[13 b, 15]}$ For hydrolysis, the solute and the hydrolytic products should ideally have high solubility in water, and form no hydrates, e.g. $\mathrm{NaBO}_{2} \cdot 2 \mathrm{H}_{2} \mathrm{O}$ in reaction 12 , so the water can be fully reacted for hydrogen release. Accordingly, compounds such as $\mathrm{NH}_{3} \mathrm{BH}_{3}$ with a high hydrogen storage capacity of $19.6 \mathrm{wt} \%$ have emerged as potential alternative to $\mathrm{NaBH}_{4}$. Like $\mathrm{NaBH}_{4}, \mathrm{NH}_{3} \mathrm{BH}_{3}$ can be hydrolysed with suitable catalysts as further detailed in recent reviews. ${ }^{[13 b, 160]}$ However, the absolute recoverable capacity is lower than the theoretical $19.6 \mathrm{wt} \%$ because the protonic part of the compound cannot be extracted with water; nonetheless slightly higher amounts of hydrogen have been recovered with $\mathrm{NH}_{3} \mathrm{BH}_{3}$ than $\mathrm{NaBH}_{4}$ (Table 8). The main problem with $\mathrm{NH}_{3} \mathrm{BH}_{3}$ is that it liberates some ammonia during hydrolysis and this is a significant issue for application especially when considering fuel cell poisoning.

One condensation up from $\mathrm{BH}_{3}$ and $\mathrm{BH}_{4}^{-}$are $\mathrm{B}_{2} \mathrm{H}_{6}$ and $\mathrm{B}_{2} \mathrm{H}_{7}^{-}$, but the former is a dangerously volatile gas and the latter is unstable at room temperature. Another condensation up is $\mathrm{B}_{3} \mathrm{H}_{7}$ and octahydrotriborate $\left(\mathrm{B}_{3} \mathrm{H}_{8}{ }^{-}\right)$. Hydride extraction from $\mathrm{B}_{3} \mathrm{H}_{8}{ }^{-}$yields $\mathrm{B}_{3} \mathrm{H}_{7}$, which normally exists as a (solvent) $\mathrm{B}_{3} \mathrm{H}_{7}$ adduct. ${ }^{[161]}$ The potentially high hydrogen content of compounds based on $\mathrm{B}_{3} \mathrm{H}_{7}$ and $\mathrm{B}_{3} \mathrm{H}_{8}{ }^{-}$has thus generated significant research into their synthesis and hydrogen storage properties. This includes compounds such as $\mathrm{NH}_{3} \mathrm{~B}_{3} \mathrm{H}_{7}$, $\mathrm{NaB}_{3} \mathrm{H}_{8},{ }^{[162]} \mathrm{NH}_{4} \mathrm{~B}_{3} \mathrm{H}_{8},{ }^{[163]}\left(\mathrm{NH}_{3}\right)_{2} \mathrm{BH}_{2} \mathrm{~B}_{3} \mathrm{H}_{8},{ }^{[164]}$ and $\left(\mathrm{NH}_{2}\right)_{4} \mathrm{CB}_{3} \mathrm{H}_{8} \cdot{ }^{[165]}$ Hence, ammonia triborane $\left(\mathrm{NH}_{3} \mathrm{~B}_{3} \mathrm{H}_{7}\right)$, a compound known since $1959,{ }^{[166]}$ was recently synthesised through a convenient and safe route involving the iodine oxidation of $\mathrm{Bu}_{4} \mathrm{~N}^{+} \mathrm{B}_{3} \mathrm{H}_{8}{ }^{-}$following reaction $(13):^{[167]}$

$$
\mathrm{Bu}_{4} \mathrm{~N}^{+} \mathrm{B}_{3} \mathrm{H}_{8}{ }^{-}+1 / 2 \mathrm{I}_{2}+\text { glyme } \rightarrow(\text { glyme }) \mathrm{B}_{3} \mathrm{H}_{7}+\mathrm{Bu}_{4} \mathrm{NI}+1 / 2 \mathrm{H}_{2}
$$


According to Yoon et al., $\mathrm{NH}_{3} \mathrm{~B}_{3} \mathrm{H}_{7}$ is more stable in aqueous solution than $\mathrm{NH}_{3} \mathrm{BH}_{3}$ and $\mathrm{NaBH}_{4}$ (Table 8) and should afford better hydrogen release performances. ${ }^{[161,167]}$

A new route has been developed for the synthesis of $\mathrm{NH}_{4} \mathrm{~B}_{3} \mathrm{H}_{8}$. Ammonium octahydrotriborate $\left(\mathrm{NH}_{4} \mathrm{~B}_{3} \mathrm{H}_{8}\right)$ was synthesized 40 years ago through the reaction between pentaborane and liquid ammonia. ${ }^{[163]}$ Beyond this synthesis, little information is available in terms of structure and properties. This is likely because pentaborane is dangerous and toxic, and not commercially available. Huang et al. recently developed a new route to high purity $\mathrm{NH}_{4} \mathrm{~B}_{3} \mathrm{H}_{8}$ by reacting $\mathrm{NaB}_{3} \mathrm{H}_{8}$ with $\mathrm{NH}_{4} \mathrm{Cl}$ in liquid ammonia. ${ }^{[163]}$ This metathesis affords a mixture of $\mathrm{NaCl}$ and $\mathrm{NH}_{4} \mathrm{~B}_{3} \mathrm{H}_{8}$. After removing the ammonia, dry THF is used to dissolve and isolate the $\mathrm{NH}_{4} \mathrm{~B}_{3} \mathrm{H}_{8}$.

Some key advantages of these new compounds, e.g. $\mathrm{NaB}_{3} \mathrm{H}_{8}$, is the high solubility of the hydrolytic products compared with those of $\mathrm{NaBH}_{4}$ (Table 8). It has been reported that the metal to boron ratio greatly determines the solubility of borates in aqueous solution, with the $1: 3$ ratio of $\mathrm{Na}$ to $\mathrm{B}$ contributing to the formation of highly soluble borates. Recent studies have shown that after adding extra water to maintain a single liquid phase, the $\mathrm{NaB}_{3} \mathrm{H}_{8}$ system can provide $6.5 \mathrm{wt} \% \mathrm{H}_{2}$, while $\mathrm{NaBH}_{4}$ can afford only $4.6 \mathrm{wt} \% \mathrm{H}_{2}{ }^{[168]}$

During thermolysis all these compounds give off $\mathrm{H}_{2}$ at low temperatures, i.e. $\sim 100{ }^{\circ} \mathrm{C}$, and volatiles including $\mathrm{NH}_{3}, \mathrm{~B}_{2} \mathrm{H}_{6} \cdot{ }^{[165,169]}$ The amount and type of volatiles obviously vary among the different compounds, depending upon the $\mathrm{H}^{\delta+}: \mathrm{H}^{\delta-}$ ratio. In $\mathrm{NH}_{3} \mathrm{BH}_{3}$, where the ratio of two types of $\mathrm{H}$ is $1: 1$, thermal decomposition alone yields high purity $\mathrm{H}_{2}$ with traces of $\mathrm{NH}_{3}, \mathrm{~B}_{2} \mathrm{H}_{6}$, and $\mathrm{B}_{3} \mathrm{~N}_{3} \mathrm{H}_{6} .{ }^{37,38}$ However in $\left[\left(\mathrm{NH}_{3}\right)_{2} \mathrm{BH}_{2}\right] \mathrm{B}_{3} \mathrm{H}_{8}\left(\mathrm{H}^{\delta+}: \mathrm{H}^{\delta-}\right.$ ratio of $\left.3: 5\right)$ or $\mathrm{NH}_{4} \mathrm{~B}_{3} \mathrm{H}_{8}\left(\mathrm{H}^{\delta+}: \mathrm{H}^{\delta-}\right.$ of 3:6 ratio $)$ higher amounts of undesirable boron hydrides, especially $\mathrm{B}_{2} \mathrm{H}_{6}$ and $\mathrm{B}_{5} \mathrm{H}_{9}$ are obtained. ${ }^{[165]}$ Other compounds based on bigger polynuclear borane anions including closo- $\mathrm{B}_{10} \mathrm{H}_{10}{ }^{2-}$, nido- $\mathrm{B}_{11} \mathrm{H}_{14^{-}}$, and closo- $\mathrm{B}_{12} \mathrm{H}_{12}{ }^{2-}$ have also been reported. ${ }^{[170]}$ However, such compounds may no present significant benefit over lighter boranes. 
To improve the thermolysis properties of $\mathrm{NH}_{3} \mathrm{BH}_{3}$ and possibly enable reversibility, the substitution of one of the hydrogen atoms by an alkali or alkaline earth element has also been investigated. The first synthesis of an amidoborane, i.e. $\mathrm{NaNH}_{2} \mathrm{BH}_{3}$, was reported in 1938 by Schlesinger and Braun. ${ }^{[171]}$ Lithium amidoborane was synthesised more recently by Myers et al by reacting n-butyllithium and $\mathrm{NH}_{3} \mathrm{BH}_{3} \cdot{ }^{[172]}$ However, its use was limited to that of a reducing reagent. The first report in 2008 of the synthesis of lithium and sodium amidoborane by mechanical milling and potential for low hydrogen desorption temperatures without unwanted by-products triggered extensive investigations on these compounds. ${ }^{[173]}$ As a general synthetic path, the direct reaction of a metal hydride of strong lewis basicity with $\mathrm{NH}_{3} \mathrm{BH}_{3}$ leads to the corresponding metal amidoborane. ${ }^{[174]}$ As summarised in Table 9, several amidoboranes have been synthetised to date and some release significant amounts of hydrogen below $100{ }^{\circ} \mathrm{C}$. However, hydrogen release from these compounds is still irreversible.

\section{High capacity amine based compounds}

Amide compounds have been known for a long time. The early syntheses, i.e. $\mathrm{NaNH}_{2}$ and $\mathrm{KNH}_{2}$, were made by Lussac and Thernard in $1809 .{ }^{[175]}$ The first synthesis of $\mathrm{LiNH}_{2}$ was reported in 1894 by Titherley, ${ }^{[176]}$ and the synthesis and hydrogen interaction of a range of amides were systematically summarized by Berstrom and Fernelius. ${ }^{[177]}$ Hydrogen uptake by $\mathrm{Li}_{3} \mathrm{~N}$ was first observed in 1910 by Dafert et al. ${ }^{[178]}$ and since the rediscovery of this possibility in 2002 by Chen et al., ${ }^{[179]}$ the combined $\mathrm{LiNH}_{2}-\mathrm{LiH}$ has largely evolved toward the more practical $\mathrm{KH}$ doped- $\mathrm{Mg}\left(\mathrm{NH}_{2}\right)_{2}-\mathrm{LiH}$ system that is reversible below $150{ }^{\circ} \mathrm{C}$ with relatively fast kinetics. ${ }^{[180]}$ However, this is at the expense of storage capacity, since the later dropped to $\sim 3$ wt $\% \mathrm{H}_{2}$ instead of the 10.5 wt $\% \mathrm{H}_{2}$ of $\mathrm{LiNH}_{2}-\mathrm{LiH}$.

The $\mathrm{LiNH}_{2}-\mathrm{LiH}$ system stores hydrogen following two main reaction paths (14a and b): 


$$
\begin{array}{ll}
\mathrm{LiNH}_{2}+\mathrm{LiH} \leftrightarrow \mathrm{Li}_{2} \mathrm{NH}+\mathrm{H}_{2} & 5.5 \mathrm{wt} \% \mathrm{H}_{2} \\
\mathrm{Li}_{2} \mathrm{NH}+\mathrm{LiH} \leftrightarrow \mathrm{Li}_{3} \mathrm{~N}+2 \mathrm{H}_{2} & 5.2 \mathrm{wt} \% \mathrm{H}_{2}
\end{array}
$$

However, the system exhibits an equilibrium plateau pressure of $\sim 0.01$ bar at $255{ }^{\circ} \mathrm{C}$ for reaction (14a) and $\sim 1$ bar at $280{ }^{\circ} \mathrm{C}$ for the second reaction, which is too high for mobile applications. Furthermore, the system suffers from sluggish kinetics (several hours at 250 $\left.{ }^{\circ} \mathrm{C}\right)^{[181]}$ and this was attributed to energy barriers associated with mass transport and ionic diffusion. ${ }^{[21 \mathrm{~d}]}$ Since, amides mainly decompose by releasing $\mathrm{NH}_{3}$, another issue is the partial release of $\mathrm{NH}_{3}$ at the ppm level. Appropriate mixing may minimize $\mathrm{NH}_{3}$ release, ${ }^{[182]}$ however irreversible loss of ammonia will undoubtedly compromise reversibility and also practical application due to potential fuel cell poisoning. ${ }^{[183]}$

The exact decomposition mechanism of $\mathrm{LiNH}_{2}-\mathrm{LiH}$ is still uncertain. As part of the early hypotheses was a $\mathrm{NH}_{3}$ mediated process whereby $\mathrm{NH}_{3}$ liberated from $\mathrm{LiNH}_{2}$ would lead to hydrogen release once reacted with $\mathrm{LiH}^{\left[{ }^{[11 b}, 184\right]}$ The combination of $\mathrm{H}^{\delta+}$ (from $\mathrm{NH}_{3}$ ) and $\mathrm{H}^{\delta-}$ (from $\mathrm{LiNH}_{2}$ ) leading to hydrogen and involving significant mass transport is another possibility. ${ }^{[185]}$ However, it is possible that both mechanisms coexist depending upon the state of the material. ${ }^{[186]}$ The formation of non-stoichiometric intermediate species in the form of $\mathrm{Li}_{1-\mathrm{x}} \mathrm{NH}_{2-\mathrm{x}}$ has also been observed, ${ }^{[187]}$ and the propagation of Frenkel disorder on the $\mathrm{Li}$ sublattice leading to migration of both $\mathrm{Li}^{+}$and $\mathrm{H}^{+}$proposed as the main mechanism. ${ }^{[188]}$ Efforts to improve $\mathrm{Li}^{+}$conductivity by introducing $\mathrm{Ti}$ additives, ${ }^{[189]}$ or $\mathrm{BN}^{[35 \mathrm{a}]}$ have led to some kinetic improvements. The addition of $\mathrm{Si}$ has also been proposed to improve $\mathrm{H}^{+}$ diffusion. ${ }^{[190]}$ Furthermore, through partial substitution of $\mathrm{H}_{2}$ by $20 \mathrm{~mol} \% \mathrm{~N}_{2}$ a significant enhancement of the cycling capacity has been observed. ${ }^{[191]}$

Considering the ammonia mediated process, the substitution of $\mathrm{Mg}\left(\mathrm{NH}_{2}\right)_{2}$ decomposing at a lower temperature than $\mathrm{LiNH}_{2}$ has been quickly identified as an alternative for decreasing the dehydrogenation temperature. ${ }^{[192]}$ Indeed, the $\mathrm{Mg}\left(\mathrm{NH}_{2}\right)_{2} / \mathrm{LiH}$ system 
exhibits a lower enthalpy $\left(38.9 \mathrm{~kJ} \cdot \mathrm{mol}^{-1} \mathrm{H}_{2}\right)$ and entropy $\left(112 \mathrm{~J} \cdot \mathrm{K}^{-1} \cdot \mathrm{mol}^{-1} \mathrm{H}_{2}\right)$ corresponding to an equilibrium pressure of 1 bar at $90{ }^{\circ} \mathrm{C} \cdot{ }^{[193]}$ However, full hydrogen release can only be achieved at temperatures above $180{ }^{\circ} \mathrm{C}$ owing to kinetics limitations. ${ }^{[193]} \mathrm{Mg}\left(\mathrm{NH}_{2}\right)_{2}-2 \mathrm{LiH}$ has a storage capacity of $5.6 \mathrm{wt} \%$ following reactions (15a and b)

$$
\begin{aligned}
& 2 \mathrm{Mg}\left(\mathrm{NH}_{2}\right)_{2}+4 \mathrm{LiH} \leftrightarrow \mathrm{Li}_{2} \mathrm{Mg}_{2}(\mathrm{NH})_{3}+\mathrm{LiNH}_{2}+\mathrm{LiH}+3 \mathrm{H}_{2} \\
& \mathrm{Li}_{2} \mathrm{Mg}_{2}(\mathrm{NH})_{3}+\mathrm{LiNH}_{2}+\mathrm{LiH} \leftrightarrow 2 \mathrm{Li}_{2} \mathrm{Mg}(\mathrm{NH})_{2}+\mathrm{H}_{2}
\end{aligned}
$$

$\mathrm{Mg}\left(\mathrm{NH}_{2}\right)_{2}$ is not commercially available and was first synthesized by the reaction of $\mathrm{Mg}_{3} \mathrm{~N}_{2}$ or $\mathrm{Mg}$ with ammonia but alternative approaches using ball-milling have been since developed. ${ }^{[192 \mathrm{a}, 192 \mathrm{~b}]}$ Different molar ratios of the $\mathrm{Mg}\left(\mathrm{NH}_{2}\right)_{2}-\mathrm{LiH}$ mix have also been investigated, ${ }^{[192 b, 194]}$ but it appears that the $1: 2$ ratio leads to the highest possible capacity at the lowest operating temperature. As summarized Table 10, various additives have been tested to improve the hydrogen properties of amide systems. For the $\mathrm{Mg}\left(\mathrm{NH}_{2}\right)_{2}-\mathrm{LiH}$ system a notable improvement was achieved by the introduction of 3 mol \% of KH. ${ }^{[180,195]}$ Such improvement has been explained by the formation of the $\mathrm{K}_{2} \mathrm{Mg}\left(\mathrm{NH}_{2}\right)_{4}$ intermediate, with weaker $\mathrm{N}-\mathrm{H}$ bonds than in $\mathrm{Mg}\left(\mathrm{NH}_{2}\right)_{2}{ }^{[195]}$

Additional strategies to improve the hydrogen properties of amide systems could be through nanosizing/nanoconfinement approaches. As previously discussed, at small particle sizes kinetic limitations due to ionic transport and thermodynamics could be enhanced. The difficulty of synthesizing nanosized amides has limited investigations along this path, although a few nano-objects, including hollow $\mathrm{Li}_{2} \mathrm{NH},{ }^{[196]}$ and $\mathrm{Li}_{3} \mathrm{~N}$ nanofibers, ${ }^{[197]}$ have been synthesized with sometimes some improvement in cycling stability and kinetics.

\section{High capacity aluminium containing compounds}


The first synthesis of aluminium hydride $\left(\mathrm{AlH}_{3}\right)$ was reported in 1947 by Finholt et al. ${ }^{[198]}$ and in 1955 a non-solvated form by Chizinsky. ${ }^{[199]}$ Because $\mathrm{AlH}_{3}$ is unstable the reaction is carried out in donating solvents, e.g. ethers, amines or THF, the solvent is then removed by heating under vacuum. $\mathrm{AlH}_{3}$ is a covalently bonded binary hydride with different polymorphic structures $(\alpha, \alpha, \beta$ and $\gamma$ ) all strongly dependent upon variations of the common synthetic process $^{[198]}$ and all thermodynamically unstable at room temperature but kinetically metastable. ${ }^{[16 a]}$ Furthermore, $\alpha^{\prime}, \beta$ and $\gamma$ all transform into $\alpha-\mathrm{AlH}_{3}$ at temperatures $\geq 100{ }^{\circ} \mathrm{C}$ and $\alpha-\mathrm{AlH}_{3}$ decomposes via a one-step reaction mechanism (16):

$$
\alpha-\mathrm{AlH}_{3} \rightarrow \mathrm{Al}+3 / 2 \mathrm{H}_{2}
$$

This reaction is kinetically limited and thus can be controlled via a reduction of particle size or with appropriate additives. ${ }^{[16 a, 200]}$ The reverse reaction is possible but with hydrogen pressures $>7 \mathrm{kbar}$, and hydrogen absorption is not possible in Al nanoparticles, even up to 2 kbar. ${ }^{[201]}$ Accordingly, the common synthetic route remains the metathesis reaction involving $\mathrm{LiAlH}_{4}$ and $\mathrm{AlCl}_{3}$ although alternative electrochemistry, ${ }^{[202]}$ organic adducts, ${ }^{[203]}$ and solvent free methods ${ }^{[204]}$ have been developed. In the current state, $\mathrm{AlH}_{3}$ may be suitable for hydrogen generation at low temperatures, although its cost effective regeneration could be problematic. The properties of $\mathrm{AlH}_{3}$ are summarized in Table 11.

Since aluminium hydride can also form anions, i.e. $\left[\mathrm{AlH}_{4}\right]^{-}$and $\left[\mathrm{AlH}_{6}\right]^{3-}$, stabilized by alkali (e.g. Li, $\mathrm{Na}$ ) alkaline earth (e.g. $\mathrm{Mg}$ and $\mathrm{Ca}$ ) or transition metal (e.g. Zn) cations the alternative is to store hydrogen with complexes of aluminium hydride. Bogdanović and Schwickardi trigged efforts in this area with the discovery of reversibility in Ti-doped $\mathrm{NaAlH}_{4}$ under mild conditions of temperatures and pressures. ${ }^{[20]} \mathrm{NaAlH}_{4}$ decomposes following the reactions:

$$
\begin{aligned}
& 3 \mathrm{NaAlH}_{4} \rightarrow \mathrm{Na}_{3} \mathrm{AlH}_{6}+2 \mathrm{Al}+3 \mathrm{H}_{2} \quad\left(3.75 \text { wt } \% \mathrm{H}_{2} \text { at } 170-230{ }^{\circ} \mathrm{C}\right) \\
& \mathrm{Na}_{3} \mathrm{AlH}_{6} \rightarrow 3 \mathrm{NaH}+\mathrm{Al}+3 / 2 \mathrm{H}_{2}
\end{aligned}
$$




$$
3 \mathrm{NaH} \rightarrow 3 \mathrm{Na}+3 / 2 \mathrm{H}_{2} \quad\left(1.8 \text { wt } \% \mathrm{H}_{2}>400{ }^{\circ} \mathrm{C}\right)
$$

Hydrogen release from uncatalysed $\mathrm{NaAlH}_{4}$ in reaction $(17 \mathrm{a}$ and $\mathrm{b}$ ) takes more than $50 \mathrm{~h}$ at temperatures below the melting point of $\mathrm{NaAlH}_{4}$, i.e. $183^{\circ} \mathrm{C}$ and only these two reactions are practical. ${ }^{[205]}$ The first direct hydrogenation was reported by Dymova et al at $270{ }^{\circ} \mathrm{C}$ and 175 bar hydrogen pressure. ${ }^{[206]}$ However, Ti-doped $\mathrm{NaAlH}_{4}$ was found to release hydrogen before melting at $150{ }^{\circ} \mathrm{C}$ and full rehydrogenation was achieved in $5 \mathrm{~h}$ at $170{ }^{\circ} \mathrm{C}$ and 152 bar of hydrogen. ${ }^{[20]}$ Since then, several strategies have been developed to optimise this system including improved synthesis methods (e.g. ball-milling), ${ }^{[207]}$ cycling stability (up to $4 \mathrm{wt}$ $\%),{ }^{[208]}$ and more effective catalysts. ${ }^{[209]}$ The mode of action of the catalyst is however still debated. Assuming $\mathrm{TiCl}_{3}$ as the source of catalyst doping, metallic titanium will end up highly dispersed during ball milling via the following metathesis reaction (18): ${ }^{[210]}$

$$
3 \mathrm{NaAlH}_{4}+\mathrm{TiCl}_{3} \rightarrow \mathrm{Ti}+3 \mathrm{Al}+3 \mathrm{NaCl}+6 \mathrm{H}_{2}
$$

which may lead to the formation of TiAl alloys such as $\mathrm{TiAl}_{3}{ }^{[210 b]}$ However, theoretical calculations predicted additional charge states for $\mathrm{Ti}$ with an energetically favoured substitution of $\mathrm{Al}$ sites by Ti leading to Ti with an overall charge state of -1 compensated by a positively charged $\mathrm{AlH}_{4} \cdot{ }^{[211]}$ The later would facilitate the mass transport form the segregated phases, i.e. $\mathrm{NaH}$ and $\mathrm{Al}$. Recent NMR investigations ${ }^{[212]}$ and inelastic neutron scattering ${ }^{[213]}$ have shown the presence of mobile $\mathrm{Al}_{\mathrm{x}} \mathrm{H}_{\mathrm{y}}$ species. The role of $\mathrm{Ti}$ in helping the dissociation of molecular hydrogen has also been suggested, ${ }^{[214]}$ however this may not correspond to the main rate limiting step during rehydrogenation. ${ }^{[215]}$ Experimental data also indicate that Al-Ti nanoparticles on the surface of $\mathrm{NaAlH}_{4}$ play a bifunctional role in both dissociating $\mathrm{H}_{2}$ and facilitating low temperature Al-H bond breaking. ${ }^{[138]}$

Although achieving reversibility with Ti-doped $\mathrm{NaAlH}_{4}$ has been a major breakthrough, a number of issues including kinetics and associated heat management, capacity and safety (e.g. high reactivity with water) have clouded the practical application of 
such a material. Prototype hydrogen storage tank based on Ti-doped $\mathrm{NaAlH}_{4}$ have demonstrated an overall storage capacity of $2 \mathrm{wt} \%$ along with rapid hydrogen evolution $\left(0.02 \mathrm{~g} \mathrm{H}_{2} . \mathrm{s}^{-1}\right) .{ }^{[216]}$

The success achieved with $\mathrm{NaAlH}_{4}$ has unfortunately been difficult to translate to other complex aluminium hydrides (Table 11) and in particular $\mathrm{LiAlH}_{4}$ with the highest theoretical capacity among alanates. ${ }^{[64 a, 217]}$ As summarized in Table 11 , the addition of Ti based catalysts to other alanates mainly lead to a reduction of dehydrogenation temperature and no reversibility. Unlike sodium and potassium, the enthalpy of hydrogenation of $\mathrm{Li}_{3} \mathrm{AlH}_{6}$ to $\mathrm{LiAlH}_{4}$ is endothermic and thus not favourable given that the associated entropy must be negative. However, based on the early work of Ashby et al. ${ }^{[18]}$ - proving the direct synthesis from $\mathrm{LiH}$ and $\mathrm{Al}$ in an ether solvent at 350 bar and $120^{\circ} \mathrm{C}$ feasible - more favourable thermodynamic paths have been developed to generate solvated $\mathrm{LiAlH}_{4}$ by using organic adducts. ${ }^{[219]}$ Lui et al. further improved the process by using dimethyl ether, a solvent volatile at room temperature eliminating the need of further purification steps. ${ }^{[220]}$ According to recent high pressure NMR investigations the direct synthesis of $\mathrm{LiAlH}_{4} .4 \mathrm{THF}$ does not proceed through the $\mathrm{Li}_{3} \mathrm{AlH}_{6}$ route. ${ }^{[221]}$ Hence, finding a way to bypass this route should lead to reversibility from the elements only.

As for borohydrides, a direct correlation exists between the cation electronegativity and the bond strength (Figure 11). ${ }^{[13 a]}$ Therefore, it should be possible to tune the thermodynamics of alanates by partial substitution of the cation. Various mixed cations aluminium hydrides have been synthesised and indeed a shift in the equilibrium plateau pressure has been observed for some, e.g. for $\mathrm{Na}_{2} \mathrm{LiAlH}_{6}$ and $\mathrm{K}_{2} \mathrm{NaAlH}_{6},{ }^{[222]}$ but at the expense of the gravimetric capacity.

Additional strategies are through a destabilisation approach via the reaction with other hydrides or via the control of particle size by nanoconfinement (Table 5, 9 and 12). Hence the 
ternary $\mathrm{LiAlH}_{4}-\mathrm{MgH}_{2}-\mathrm{LiBH}_{4}$ led to some reversibility but at $400{ }^{\circ} \mathrm{C}^{[125]}$ Upon nanoconfinement, $\mathrm{NaAlH}_{4}{ }^{[223]}$ and $\mathrm{LiAlH}_{4}{ }^{[224]}$ showed low hydrogen desorption temperatures and in porous carbon, reversibility for $\mathrm{NaAlH}_{4}$ was achieved under much milder conditions, i.e. 24 bar hydrogen pressure at $150{ }^{\circ} \mathrm{C},{ }^{[225]}$ instead of the 60 bar required for bulk $\mathrm{NaAlH}_{4}$ at the same temperature. Fichtner et al. also found a single equilibrium plateau pressure for nanoconfined $\mathrm{NaAlH}_{4}$ indicating a single step reaction and/or loss of long range order that could explain the milder conditions required for reversibility. ${ }^{[226]}$

\section{Emerging applications}

The complexity of the (de)hydrogenation reaction of complex hydrides and the lack of reversibility currently hinders applications although several prototype tanks have been built and tested mainly with $\mathrm{NaAlH}_{4}$ and $\mathrm{Mg}\left(\mathrm{NH}_{2}\right)_{2}-\mathrm{LiH}^{[216,227]}$ Nonetheless, in recent years the rapid deployment of renewables has emerged as a potential niche market particularly for hydrogen as an energy vector. An example is the development of container scale systems by McPhy Energy, based on magnesium hydride for providing long term energy storage solutions. The containment tank developed for this application has been reviewed elsewhere. ${ }^{[228]}$ Another emerging application is the use of metal hydrides for energy storage media for concentrating solar thermal power (CSP) stations. ${ }^{[229]}$ Energy storage is critical for CSP applications to allow 24/7 power generation, enabling base-load power supply. The current state-of-the-art energy storage technology utilises the specific heat of molten nitrate salts, storing energy by allowing the salt to heat up to $565{ }^{\circ} \mathrm{C}$ and cool. Heat energy is stored in the salt during the day when excess solar energy is harvested. At night, heat energy is extracted from the salt and used to power a steam turbine generating electricity. Nitrate salts are relatively cheap ( $\$ 0.75$ per $\mathrm{kg}$ ). However, enormous quantities of salt are required to 
store sufficient quantities of energy for large scale CSP plants. For example, $10 \mathrm{~h}$ of heat storage at the Crescent Dunes plant built by Solar Reserve in Navada, US requires about 32,000 metric tons of molten salts. ${ }^{[229 b]}$ The large quantity of salt contributes a significant cost to the solar thermal plant.

The enthalpy of hydrogen absorption and desorption in a metal hydride is typically much higher than the specific heat available from molten nitrate salts. ${ }^{[229]}$ This means that an energy storage system utilising metal hydrides could require a much lower quantity of energy storage material, hence reducing the cost of the energy storage system. In this system, solar energy is used to release hydrogen gas from a "high temperature" metal hydride (MH_Thigh). The hydrogen released in then stored in a "low temperature hydride" ( $\mathrm{M}$ 'H_T $\left.\mathrm{T}_{\text {low }}\right)$. When energy is needed, the reaction is reversed, i.e. hydrogen is allowed to be released from MH_T $T_{\text {low }}$ into $M \mathrm{MH}_{-} \mathrm{T}_{\text {high }}$ resulting in an exothermic reaction, generating heat, which can then be used to generate electricity (Figure 14).

\subsection{Metal hydride operating parameters for application in concentrating solar thermal power}

The cost of a metal hydride thermal energy store should be cheaper than existing nitrate salt storage, where a cost of $\$ 10-20$ per $\mathrm{MJ}$ of thermal energy exists depending on the CSP design parameters. ${ }^{[230]}$ In addition to cost, several parameters have to be considered when selecting metal hydrides for CSP. These include: thermodynamics, kinetics, thermal conductivity and cycling stability.

The operating temperature of both $\mathrm{MH}_{-} \mathrm{T}_{\text {high }}$ and $\mathrm{M}^{\prime} \mathrm{H}_{-} \mathrm{T}_{\text {low }}$ are important factors in defining the efficiency of a metal hydride based CSP system, and temperatures around 400 ${ }^{\circ} \mathrm{C}$ have been suggested in the past as optimal operating conditions. ${ }^{[231]}$ Ideally, candidates for MH_Thigh should have a large $\Delta H$ in order to maximize the amount of heat generated per 
amount of metal hydride. Vice versa to maximise the overall efficiency of the system, candidates for $\mathrm{M}^{\prime} \mathrm{H}_{-} \mathrm{T}_{\text {low }}$ should involve small values of $\Delta H$ in order to minimise the amount of heat that needs to be dissipated during the absorption process (day cycle) or supplied during the night cycle. The operating temperature will also govern to some extent the kinetics of both hydrides, since fast kinetics are often achieved at higher temperatures. Ideally, the hydrogen kinetics of $\mathrm{MH}_{-} \mathrm{T}_{\text {high }}$ should be fast enough to ensure a rapid desorption upon solar irradiation but also a constant supply of heat during the night cycle. This involves faster kinetics for $\mathrm{M}^{\prime} \mathrm{H}_{-} \mathrm{T}_{\text {low }}$ as compared to $\mathrm{M}^{\prime} \mathrm{H}_{-} \mathrm{T}_{\text {high }}$, but these kinetic requirements are much less demanding than for automotive applications, where hydrogen release and uptake need to be completed over a $\sim 8 \mathrm{~h}$ time scale. Furthermore, these kinetics should be stable over multiple cycles to ensure at least 10,000 cycles occur over an expected 30 year lifecycle. Materials such as $\mathrm{CaNi}_{5}$ have fast kinetics but present significant storage capacity loss upon hydrogen cycling due to the formation of "stable" hydrides. ${ }^{[232]}$

The thermal conductivity of the metal hydride bed is another important parameter to ease the management of the ex(end)othermic reaction during hydrogen ab(des)sorption and prevent a "self-heating" or "self-cooling" of the hydride bed. Localised temperature variations will alter the hydrogen equilibrium pressure over the bed, causing some regions of the metal/hydride to absorb whilst others desorb. However, various strategies including thermal ballast ${ }^{[233]}$ have been used to overcome such an issue. The thermal conductivities of low-temperature metal hydrides are generally $\sim 1-2 \mathrm{~W} \cdot \mathrm{m}^{-1} \cdot \mathrm{K}^{-1},{ }^{[234]}$ and this value can vary depending on the state/compaction of the metal/hydride powder and the additives used. For example, upon addition of powders/foams/meshes of $\mathrm{Al}, \mathrm{Cu}, \mathrm{Ni}$ and stainless steel the thermal conductivity of $\mathrm{LaNi}_{5}$ has been increased to $32.5 \mathrm{~W} \cdot \mathrm{m}^{-1} \cdot \mathrm{K}^{-1} \cdot{ }^{[234]}$ Similarly thermal conductivities of $7-9 \mathrm{~W} \cdot \mathrm{m}^{-1} \cdot \mathrm{K}^{-1}$ have been reported for TiFe with $10 \mathrm{wt} \% \mathrm{Al} \cdot{ }^{[235]}$ However, 
both the addition of heat conducting elements or of a heat storage material within the hydride bed adds additional cost to the tank system whilst reducing the storage capacity.

\subsection{Potential metal hydrides for application in concentrating solar thermal power}

Table 13 summarises potential $\mathrm{MH}_{-} \mathrm{T}_{\text {high }}$ whilst typical $\mathrm{MH}_{-} \mathrm{T}_{\text {low }}$ materials have recently been reported elsewhere. ${ }^{[236]}$ It is important to note that the thermal energy content $\left(\mathrm{kJ} \mathrm{kg}^{-1}\right)$ and hydrogen capacity (wt \%) of a MH_T high will determine how much of the MH_ $\mathrm{T}_{\text {high }}$ is required, while the enthalpy of hydrogen absorption/desorption determines how much hydrogen is required to generate a specific amount of thermal energy. As a result, it also determines how much $\mathrm{MH}_{-} \mathrm{T}_{\text {low }}$ is required to store this hydrogen and thus has a direct impact on the cost of the system. Primarily, the high operating temperature limits the choice of MH_ $\mathrm{T}_{\text {high. }}$. However, there are literally thousands of metals and alloys that can be used to store hydrogen at low temperature. ${ }^{[237]}$ However, these hydrides have relatively low capacity "heavy" hydrides that store hydrogen interstitially. ${ }^{[229]}$ Interstitial hydrides exhibit fast kinetics and low hydrogen equilibrium pressures, due to their low heat of reaction. These intermetallic compounds are usually categorised into a number of classes based on the stoichiometries of $\mathrm{AB}, \mathrm{AB}_{5}, \mathrm{AB}_{2}$ and $\mathrm{A}_{2} \mathrm{~B}$. Element $\mathrm{A}$ is usually a rare-earth or alkaline earth metal (e.g. Ca, Ti, Y, Zr, Hf, La, Ce etc) that, by itself, forms a stable hydride while element $\mathrm{B}$ is usually a transition metal that forms only unstable hydrides (e.g. $\mathrm{Cr}, \mathrm{Mn}, \mathrm{Fe}, \mathrm{Co}, \mathrm{Ni}$ ). However, taking into account a range of practical criteria such as capacity $>1$ wt $\% \mathrm{H}_{2}, \mathrm{P}_{\mathrm{eq}} \sim$ 0.1 - 40 bar at $25^{\circ} \mathrm{C}$, and the exclusion of expensive rare metals, limits the possibilities to a few hydrides including those from the $\mathrm{AB}_{2}$ class alloys such as those based on $\mathrm{Ti}$ and $\mathrm{Zr}$ and commercially available. However, one significant problem associated with the use of a lowtemperature metal hydride is the requirement for additional heat management. For example,

Groll et al. ${ }^{[238]}$ showed that $\mathrm{MgH}_{2}$ at $400{ }^{\circ} \mathrm{C}$ generates pressures high enough for the low- 
temperature hydride to absorb at $\sim 30{ }^{\circ} \mathrm{C}$. During hydrogen absorption however, the lowtemperature hydride self-heats to $\sim 80{ }^{\circ} \mathrm{C}$ which in turn requires the $\mathrm{MgH}_{2}$ to rise to $480{ }^{\circ} \mathrm{C}$ for the reaction to continue. Conversely, during hydrogen desorption from the lowtemperature hydride, its temperature decreases to $-10{ }^{\circ} \mathrm{C}$, which requires the $\mathrm{MgH}_{2}$ to drop to $320^{\circ} \mathrm{C}$ for the reaction to continue. If the heat developed by the low-temperature hydride during absorption is not stored and re-used to help release the hydrogen later, it represents a significant energy loss in the system (up to $50 \%$ ). An alternative option is thus to store hydrogen as a compressed gas and this may present cost benefits for $\mathrm{MH}_{-} \mathrm{T}_{\text {high }}$ operating below $400{ }^{\circ} \mathrm{C} .{ }^{[239]}$

\section{Conclusions and outlook}

The present review provides an overview of the progress of high capacity materials storing hydrogen via physisorption or chemisorption. In the last 20 years and since the discovery of potential reversibility with complex hydrides, tremendous advancements have been made in developing a better understanding of the fundamental properties of complex hydrides, and designing new hydrogen storage materials. For example, $\mathrm{NaAlH}_{4}$ has been brought to the threshold of commercialisation with several prototype tanks proving the potential of complex hydrides. Similarly, the hydrogen storage properties of the newly discovery amide systems have been brought close to practical viability. Many borohydrides have now been designed to reversibly store hydrogen to some extent and their combination with ammonia has provided new compounds for low temperatures hydrogen production. However, these "improved" complex hydrides still suffer from many limitations such as low reversible hydrogen capacity and slow kinetics and as summarized Figure $2 \mathrm{~b}$ none meet the requirements for vehicles application. The tremendous achievements with $\mathrm{NaAlH}_{4}$ have not been transferred to $\mathrm{LiAlH}_{4}$ of much higher storage capacity. Borohydrides still suffer from 
very slow kinetics but most remarkably high temperatures for hydrogen cycling. Furthermore, amides are limited by low storage capacity and mass transport. New strategies such as $\mathrm{H}^{\delta+} / \mathrm{H}^{\delta-}$ interaction and destabilisation through mixed complex hydrides have also been developed to overcome these limitations, but these approaches start to show their limitations.

Many of the current barriers exist due to a lack of fundamental understanding and effective approaches to modify the properties of well-known high capacity hydrides. To a large extent little is known about the basic physical and chemical properties of complex hydrides in particular under reactive conditions, despites their early synthesis a century ago. This will require advanced in-situ characterisation tools coupled with modelling to draw accurate reaction mechanisms of complex (de)hydrogenation reactions. In particular, current knowledge needs to be extensively extended outside the conventional understanding of metal hydrides. The interaction of metal hydrides with hydrogen involves a single step reaction thoroughly investigated throughout the $20^{\text {th }}$ century. Although some of this knowledge is transferable to complex hydrides, the inherent complexity of their decomposition mechanisms challenges current understanding. For example, little is known about kinetic barriers for the formation or dissociation of $\mathrm{AlH}_{4}{ }^{-}$or $\mathrm{BH}_{4}{ }^{-}$and even hydrogen activation at complex hydrides' interfaces. Similarly, the nucleation and growth of specific (de)hydrogenation phases and associated reaction morphologies are poorly understood as well as the thermodynamics of disordered hydrides. Entropic evolutions and potential effects on the overall hydrogen properties of complex hydrides need to be more accurately determined, so it can effectively be used to adjust the thermodynamics of complex hydrides. This has currently been limited by the lack of experimental methods to effectively determine the entropy of complex dehydrogenation processes. Accordingly, new tools need to be developed. Another area critically missing basic understating is related to the interaction of 
hydrogen with nanosized hydrides. Nanosizing has been shown across many examples as a potential approach to positively enhance the properties of hydrides. However, this will require an accurate control over atomic assemblies and a broader multidisciplinary approach than currently existing.

Porous organic frameworks have also shown great promise through constant development of new strategies to meet both gravimetric and volumetric requirements for vehicle applications. The remaining challenge is to develop materials that can meet high capacity storage under much milder temperatures. In this regards, theoretical modelling is essential in the prediction of promising strategies and materials design.

It is noteworthy that the challenge set by government agencies and industry for hydrogen powered vehicles is more than demanding. Meeting the most stringent requirements ever forced upon a technology, i.e. cost and high-end technical solutions for immediate largescale deployment at once within such a short time frame, is unprecedented. However, with global priorities rapidly shifting from solely vehicle-based usage, the materials developed since the 1970's may find early market adoption in a demand for clean and dense energy systems. In particular, applications where hydrogen can be generated in a distributed fashion should be investigated for further use of the significant breakthroughs that have been made with storage materials. A local production/distribution of hydrogen - which has been a key limiting step in the automotive industry - may be the path to less stringent targets for an early adoption of hydrogen powered vehicles and also portable power equipment.

\section{Acknowledgements}

We gratefully acknowledge financial support received from the Australian Research Council, the Carl Tryggers Stiftelse for Vetenskaplig Forskning (CTS), Swedish Research Council (VR) and Swedish Energy Agency for financial support. SNIC and UPPMAX are 
acknowledged for providing computing time. M.P. acknowledges financial support from The Danish Council for Independent Research for DFF Mobility 1325-00072. Valuable discussions and collaboration with the group of A Züttel and A. Brogschulte are highly appreciated.

\section{Notations}

Peq $=$ Equilibrium pressure $($ bar $)$

$\mathrm{T}=$ Temperature

$\mathrm{P}=$ Pressure

$\mathrm{R}=$ Universal gas constant $(8.3144 \mathrm{~J} . \mathrm{mol}-1 . \mathrm{K}-1)$

$\Delta \mathrm{H}_{\mathrm{ads}}=$ Enthalpy of adsorption

$\Delta \mathrm{H}_{\mathrm{f}}=$ Enthalpy of formation

$\Delta \mathrm{H}_{\mathrm{des}}=$ Enthalpy of hydrogen desorption

Exp $=$ Experimentally measured

Rehydro = Rehydrogenation

Des. Rate $=$ Hydrogen desorption rate

decomp = decomposition

All hydrogen capacities reported correspond to that of the materials and not systems, i.e. tanks, otherwise specified. 


\section{References}

[1] U. Eberle, B. Muller, R. von Helmolt, Energy Environ. Sci. 2012, 5, 8780-8798.

[2] R. A. Erren, Vol. GB patent GB364180 1930.

[3] S. Verhelst, Int. J. Hydrogen Energy 2014, 39, 1071-1085.

[4] 2011 Fuel Cell Technologies Market Report, US Department of Energy, Washington D.C., USA, 2012.

[5] J. H. N. Van Vucht, F. A. Kuijpers, H. C. A. M. Bruning, Philips Research Reports 1970, 25, 133140.

[6] J. J. Reilly, R. H. Wiswall, Inorg. Chem. 1974, 13, 218-222.

[7] a) H. Buchner, Prog. Energy Combust. Sci. 1980, 6, 331-346; b) N. Gerard, S. Ono, Hydrogen in intermetallic compounds, Vol. 67, Springer-Verlag, 1992; c) K. C. Hoffman, W. E. Winsche, R. H. Wiswall, Reilly, J.J., T. V. Sheehan, C. H. Waide, Metal hydrides as a source of fuel for vehicular propulsion, 1969; d) B. Sakintuna, F. Lamari-Darkrim, M. Hirscher, Int. J. Hydrogen Energy 2007, 32, 1121-1140.

[8] J.-M. Joubert, M. Latroche, A. Percheron-Guégan, MRS Bull. 2002, 27, 694-698

[9] C. Wadell, S. Syrenova, C. Langhammer, ACS Nano 2014, 8, 11925-11940.

[10] K. Samwer, J. Less Comm. Met. 1988, 140, 25-31.

[11] a) J. N. Huiberts, R. Griessen, J. H. Rector, R. J. Wijnaarden, J. P. Dekker, D. G. deGroot, N. J. Koeman, Nature 1996, 380, 231-234; b) P. H. L. Notten, Curr. Opin. Solid State Mater. Sci. 1999, 4, 5-10.

[12] A. Unemoto, M. Matsuo, S.-I. Orimo, Adv. Funct. Mater. 2014, 24, 2267-2279.

[13] a) J. Graetz, Chem. Soc. Rev. 2009, 38, 73-82; b) M. Yadav, Q. Xu, Energy Environ. Sci. 2012, 5, 9698-9725.

[14] U. B. Demirci, O. Akdim, P. Miele, Int. J. Hydrogen Energy 2009, 34, 2638-2645.

[15] G. Moussa, R. Moury, U. B. Demirci, T. Şener, P. Miele, Int. J. Energ. Res. 2013, 37, 825-842.

[16] a) J. Graetz, J. J. Reilly, V. A. Yartys, J. P. Maehlen, B. M. Bulychev, V. E. Antonov, B. P. Tarasov, I. E. Gabis, J. Alloys Compd. 2011, 509, Supplement 2, S517-S528; b) Y. S. Chua, P. Chen, G. Wu, Z. Xiong, Chem. Commun. 2011, 47, 5116-5129.

[17] C. D. Montgomery, Nucl. Eng. Des. 1973, 25, 309-314.

[18] G. Sandrock, J. Reilly, J. Graetz, W.-M. Zhou, J. Johnson, J. Wegrzyn, Appl. Phys. A 2005, 80, 687-690.

[19] K.-F. Aguey-Zinsou, J.-R. Ares-Fernandez, Energy Environ. Sci. 2010, 3, 526-543.

[20] B. Bogdanović, M. Schwickardi, J. Alloys Compd. 1997, 253-254, 1-9.

[21] a) S.-I. Orimo, Y. Nakamori, J. R. Eliseo, A. Züttel, C. M. Jensen, Chem. Rev. 2007, 107, 41114132; b) D. Pukazhselvan, V. Kumar, S. K. Singh, Nano Energy 2012, 1, 566-589; c) I. P. Jain, P. Jain, A. Jain, J. Alloys Compd. 2010, 503, 303-339; d) H. Cao, Y. Zhang, J. Wang, Z. Xiong, G. Wu, P. Chen, Prog. Nat. Sci. 2012, 22, 550-560; e) W. Grochala, P. P. Edwards, Chem. Rev. 2004, 104, 1283-1315; f) L. H. Rude, T. K. Nielsen, D. B. Ravnsbaek, U. Boesenberg, M. B. Ley, B. Richter, L. M. Arnbjerg, M. Dornheim, Y. Filinchuk, F. Besenbacher, T. R. Jensen, Physica Status Solidi a-Applications and Materials Science 2011, 208, 1754-1773.

[22] a) G. Kubas, J. Organomet. Chem. 2001, 635, 37-68; b) J. Niu, B. K. Rao, P. Jena, Phys. Rev. Lett. 1992, 68, 2277-2280; c) J. Zhou, Q. Wang, Q. Sun, P. Jena, X. S. Chen, Proc Natl Acad Sci 2010, 107, 2801-2806.

[23] Z. Yang, Y. Xia, R. Mokaya, J. Am. Chem. Soc 2007, 129, 1673-1679.

[24] E. Poirier, R. Chahine, P. Bénard, D. Cossement, L. Lafi, E. Mélançon, T. K. Bose, S. Désilets, Appl. Phys. A 2004, 78, 961-967. 
[25] H. W. Langmi, D. Book, A. Walton, S. R. Johnson, M. M. Al-Mamouri, J. D. Speight, P. P. Edwards, I. R. Harris, P. A. Anderson, J. Alloys Compd. 2005, 404-406, 637-642.

[26] X. Lin, J. Jia, X. Zhao, K. M. Thomas, A. J. Blake, G. S. Walker, N. R. Champness, P. Hubberstey, M. Schröder, Angew. Chem. Int. Ed. 2006, 45, 7358-7364.

[27] P. M. Budd, A. Butler, J. Selbie, K. Mahmood, N. B. McKeown, B. Ghanem, K. Msayib, D. Book, A. Walton, Phys. Chem. Chem. Phys. 2007, 9, 1802-1808.

[28] A. Züttel, P. Sudan, P. Mauron, P. Wenger, Appl. Phys. A 2004, 78, 941-946.

[29] M. G. Nijkamp, J. E. M. J. Raaymakers, A. J. v. Dillen, K. P. d. Jong, Appl. Phys. A 2001, 72, 619-623.

[30] D. J. Tranchemontagne, J. L. Mendoza-Cortés, M. O’Keeffe, O. M. Yaghi, Chem. Soc. Rev. 2009, 38, 1257-1283.

[31] A. G. Wong-Foy, A. J. Matzger, O. M. Yaghi, J. Am. Chem. Soc. 2006, 128, 3494-3495.

[32] U. Eberle, M. Felderhoff, F. Schueth, Angew. Chem. Int. Ed. 2009, 48, 6608-6630.

[33] M. Schlichtenmayer, M. Hirscher, J. Mater. Chem. 2012, 22, 10134-10143.

[34] V. Bérubé, G. Radtke, M. Dresselhaus, G. Chen, Int. J. Energy Res. 2007, 31, 637-663.

[35] a) K. F. Aguey-Zinsou, J. Yao, Z. X. Guo, J. Phys. Chem. B 2007, 111, 12531-12536; b) Z. Xiong, C. K. Yong, G. Wu, P. Chen, W. Shaw, A. Karkamkar, T. Autrey, M. O. Jones, S. R. Johnson, P. P. Edwards, W. I. F. David, Nat Mater 2008, 7, 138-141.

[36] H.-W. Li, Y. Yan, S.-I. Orimo, A. Züttel, C. M. Jensen, Energies 2011, 4, 185-214.

[37] J. J. Vajo, F. Mertens, C. C. Ahn, R. C. Bowman, B. Fultz, J. Phys. Chem. B 2004, 108, 1397713983.

[38] J. J. Vajo, S. L. Skeith, F. Mertens, J. Phys. Chem. B 2005, 109, 3719-3722.

[39] a) J. J. Vajo, G. L. Olson, Scripta Mater. 2007, 56, 829-834; b) D. B. Ravnsbæk, Y. Filinchuk, R. Černý, M. B. Ley, D. Haase, H. J. Jakobsen, J. r. Skibsted, T. R. Jensen, Inorg. Chem. 2010, 49, 3801-3809; c) T. Jaron, W. Grochala, Dalton Trans. 2010, 39, 160-166.

[40] a) M. Paskevicius, M. B. Ley, D. A. Sheppard, T. R. Jensen, C. E. Buckley, Phys. Chem. Chem. Phys. 2013, 15, 19774-19789; b) P. Schouwink, M. B. Ley, A. Tissot, H. Hagemann, T. R. Jensen, L. Smrcok, R. Cerny, Nature Communications 2014, 5.

[41] a) A. J. Churchard, E. Banach, A. Borgschulte, R. Caputo, J. C. Chen, D. Clary, K. J. Fijalkowski, H. Geerlings, R. V. Genova, W. Grochala, T. Jaroń, J. C. Juanes-Marcos, B. Kasemo, G. J. Kroes, I. Ljubić, N. Naujoks, J. K. Nørskov, R. A. Olsen, F. Pendolino, A. Remhof, L. Románszki, A. Tekin, T. Vegge, M. Zäch, A. Züttel, Phys. Chem. Chem. Phys. 2011, 13, 16955-16972; b) T. Ichikawa, N. Hanada, S. Isobe, H. Leng, H. Fujii, J. Phys. Chem. B 2004, 108, 7887-7892.

[42] W. C. Conner, J. L. Falconer, Chem Rev 1995, 95, 759-788.

[43] L. Wang, R. T. Yang, Energy Environ. Sci. 2008, 1, 268-279.

[44] a) P. Hohenberg, W. Kohn, Phys. Rev. 1964, 136, B864-B871; b) W. Kohn, L. J. Sham, Phys. Rev. 1965, 140, A1133-A1138.

[45] a) T. Hussain, S. Chakraborty, T. W. Kang, B. Johansson, R. Ahuja, ChemPhysChem 2014, n/an/a; b) T. Hussain, S. Chakraborty, R. Ahuja, ChemPhysChem 2013, 14, 3463-3466; c) T. Hussain, T. Kaewmaraya, S. Chakraborty, R. Ahuja, Phys. Chem. Chem. Phys. 2013, 15, 1890018905; d) T. Hussain, S. Chakraborty, A. De Sarkar, B. Johansson, R. Ahuja, Appl. Phys. Lett. 2014, 105, 123903.

[46] a) J. P. Perdew, J. A. Chevary, S. H. Vosko, K. A. Jackson, M. R. Pederson, D. J. Singh, C. Fiolhais, Phys. Rev. B: Condens. Matter. 1992, 46, 6671; b) J. P. Perdew, Y. Wang, Phys. Rev. B 1992, 45, 13244.

[47] T. Mueller, C. Gerbrand, Phys Rev B. 2010, 82, 174307.

[48] G. Kresse, J. Hafner, Phys Rev B. 1994, 49, 14251.

[49] a) S. Gudmundsdottir, E. Skulason, K.-J. Weststrate, L. Juurlink, H. Jonsson, Phys. Chem. Chem. Phys. 2013, 15, 6323-6332; b) P. van Helden, J.-A. van den Berg, C. J. Weststrate, ACS Catalysis 2012, 2, 1097-1107.

[50] A. Togo, F. Oba, I. Tanaka, Phys. Rev. B 2008, 78, 134106. 
[51] a) K. Sumida, M. R. Hill, S. Horike, A. Dailly, J. R. Long, J. Am. Chem. Soc. 2009, 131, 15120; b) W.-X. Lim, A. W. Thornton, A. J. Hill, B. J. Cox, J. M. Hill, M. R. Hill, Langmuir 2013, 29, 85248533.

[52] a) A. Dailly, E. Poirier, Energy Environ. Sci. 2011, 4, 3527-3534; b) B. P. Prajwal, K. G. Ayappa, Adsorption 2014, 20, 769-776.

[53] M. P. Suh, H. J. Park, T. K. Prasad, D.-W. Lim, Chem. Rev. 2011, 112, 782-835.

[54] K. Sumida, M. R. Hill, S. Horike, A. Dailly, J. R. Long, J. Am. Chem. Soc. 2009, 131, 1512015121.

[55] W.-X. Lim, A. W. Thornton, A. J. Hill, B. J. Cox, J. M. Hill, M. R. Hill, Langmuir 2013, 29, 85248533.

[56] H. Frost, T. Düren, R. Q. Snurr, J. Phys. Chem. B 2006, 110, 9565-9570.

[57] C. H. Lau, R. Babarao, M. R. Hill, Chem. Commun. 2013, 49, 3634-3636.

[58] A. W. Thornton, S. A. Furman, K. M. Nairn, A. J. Hill, J. M. Hill, M. R. Hill, Microporous Mesoporous Mater. 2013, 167, 188-197.

[59] P. Kowalczyk, L. Brualla, A. Zywocinski, S. K. Bhatia, J. Phys. Chem. C 2007, 111, 5250-5257.

[60] K. W. Chapman, P. D. Southon, C. L. Weeks, C. J. Kepert, Chem. Commun. 2005, 3322-3324.

[61] A. K. Rappe, C. J. Casewit, K. S. Colwell, W. A. Goddard, W. M. Skiff, J. Am. Chem. Soc. 1992, 114, 10024-10035.

[62] J. Jia, F. Sun, Q. Fang, X. Liang, K. Cai, Z. Bian, H. Zhao, L. Gao, G. Zhu, Chem. Commun. 2011, 47, 9167-9169.

[63] K. Konstas, J. W. Taylor, A. W. Thornton, C. M. Doherty, W. X. Lim, T. J. Bastow, D. F. Kennedy, C. D. Wood, B. J. Cox, J. M. Hill, A. J. Hill, M. R. Hill, Angew. Chem. Int. Ed. 2012, 51, 6639-6642.

[64] a) J. R. Ares, K. F. Aguey-Zinsou, F. Leardini, I. J. Ferrer, J. F. Fernandez, Z. X. Guo, C. Sanchez, J. Phys. Chem. C 2009, 113, 6845-6851; b) D. P. Cao, J. H. Lan, W. C. Wang, B. Smit, Angew. Chem. Int. Ed. 2009, 48, 4730-4733; c) L. Chen, Y. Zhang, N. Koratkar, P. Jena, S. K. Nayak, Phys. Rev. B 2008, 77, 033405; d) P. Dalach, H. Frost, R. Q. Snurr, D. E. Ellis, J. Phys. Chem. C 2008, 112, 9278-9284; e) S. S. Han, W. A. Goddard, J. Am. Chem. Soc. 2007, 129, 8422-8423; f) D. Rao, R. Lu, C. Xiao, E. Kan, K. Deng, Chem. Commun. 2011, 47, 7698-7700; g) J. A. Teprovich, M. S. Wellons, R. Lascola, S. J. Hwang, P. A. Ward, R. N. Compton, R. Zidan, Nano Lett. 2012, 12, 582-589.

[65] J. Goldsmith, A. G. Wong-Foy, M. J. Cafarella, D. J. Siegel, Chem. Mater. 2013, 25, 3373-3382.

[66] a) K. S. Deeg, J. J. Gutiérrez-Sevillano, R. Bueno-Pérez, J. B. Parra, C. O. Ania, M. Doblaré, S. Calero, J. Phys. Chem. C 2013, 117, 14374-14380; b) A. A. García Blanco, A. F. Vallone, A. Gil, K. Sapag, Int. J. Hydrogen Energy 2012, 37, 14870-14880.

[67] A. Ahmed, A. W. Thornton, K. Konstas, S. K. Kannam, R. Babarao, B. D. Todd, A. J. Hill, M. R. Hill, Langmuir 2013, 29, 15689-15697.

[68] Y. J. Colón, D. Fairen-Jimenez, C. E. Wilmer, R. Q. Snurr, J. Phys. Chem. C 2014, 118, 53835389.

[69] P. Ryan, L. J. Broadbelt, R. Q. Snurr, Chem. Commun. 2008, 4132-4134.

[70] Z. Meng, R. Lu, D. Rao, E. Kan, C. Xiao, K. Deng, Int. J. Hydrogen Energy 2013, 38, 9811-9818.

[71] L. C. Lin, A. H. Berger, R. L. Martin, J. Kim, J. A. Swisher, K. Jariwala, C. H. Rycroft, A. S. Bhown, M. W. Deem, M. Haranczyk, B. Smit, Nature Materials 2012, 11, 633-641.

[72] L. Tshering, S. O. Hunter, A. Nikolich, E. Minato, C. M. Fitchett, D. M. D'Alessandro, C. Richardson, Crystengcomm 2014, 16, 9158-9162.

[73] C. M. Simon, J. Kim, L.-C. Lin, R. L. Martin, M. Haranczyk, B. Smit, Phys. Chem. Chem. Phys. 2014, 16, 5499-5513.

[74] a) A. D. Burrows, L. C. Fisher, C. Richardson, S. P. Rigby, Chem. Commun. 2011, 47, 33803382; b) A. D. Burrows, M. F. Mahon, C. L. Renouf, C. Richardson, A. J. Warren, J. E. Warren, Dalton Trans. 2012, 41, 4153-4163. 
[75] A. D. Burrows, C. G. Frost, M. F. Mahon, P. R. Raithby, C. L. Renouf, C. Richardson, A. J. Stevenson, Chem. Commun. 2010, 46, 5067-5069.

[76] a) C. Browne, S. Brenet, J. K. Clegg, J. R. Nitschke, Angew. Chem. Int. Ed. 2013, 52, 19441948; b) W. Meng, B. Breiner, K. Rissanen, J. D. Thoburn, J. K. Clegg, J. R. Nitschke, Angew. Chem. Int. Ed. 2011, 50, 3326-3326; c) W. Meng, T. K. Ronson, J. K. Clegg, J. R. Nitschke, Angew. Chem. Int. Ed. 2013, 52, 1017-1021; d) S. Zarra, J. K. Clegg, J. R. Nitschke, Angew. Chem. Int. Ed. 2013, 52, 4837-4840.

[77] a) M. B. Duriska, S. M. Neville, J. Lu, S. S. Iremonger, J. F. Boas, C. J. Kepert, S. R. Batten, Angew. Chem. Int. Ed. 2009, 48, 8919-8922; b) C. S. Hawes, S. R. Batten, D. R. Turner, Crystengcomm 2014, 16, 3737-3748.

[78] in

http://publications.jrc.ec.europa.eu/repository/bitstream/111111111/6013/1/EUR\%202099 5\%20EN.pdf.

[79] a) Y. S. Bae, R. Q. Snurr, Microporous Mesoporous Mater. 2010, 132, 300-303; b) S. K. Bhatia, A. L. Myers, Langmuir 2006, 22, 1688-1700.

[80] M. T. Kapelewski, S. J. Geier, M. R. Hudson, D. Stück, J. A. Mason, J. N. Nelson, D. J. Xiao, Z. Hulvey, E. Gilmour, S. A. FitzGerald, M. Head-Gordon, C. M. Brown, J. R. Long, J. Am. Chem. Soc. 2014, 136, 12119-12129.

[81] P. A. Szilagyi, E. Callini, A. Anastasopol, C. Kwakernaak, S. Sachdeva, R. van de Krol, H. Geerlings, A. Borgschulte, A. Zuttel, B. Dam, Phys. Chem. Chem. Phys. 2014, 16, 5803-5809.

[82] M. Majumder, P. Sheath, J. I. Mardel, T. G. Harvey, A. W. Thornton, A. Gonzago, D. F. Kennedy, I. Madsen, J. W. Taylor, D. R. Turner, M. R. Hill, Chem. Mater. 2012, 24, 4647-4652.

[83] W. Sun, S. Li, J. Mao, Z. Guo, H. Liu, S. Dou, X. Yu, Dalton Trans. 2011, 40, 5673-5676.

[84] Y. Peng, T. Ben, Y. Jia, D. Yang, H. Zhao, S. Qiu, X. Yao, J. Phys. Chem. C 2012, 116, 2569425700.

[85] S. J. Kolmann, B. Chan, M. J. T. Jordan, Chem. Phys. Lett. 2008, 467, 126-130.

[86] T. Ben, C. Pei, D. Zhang, J. Xu, F. Deng, X. Jing, S. Qiu, Energy Environ. Sci. 2011, 4, 3991-3999.

[87] H. R. Abid, H. Y. Tian, H. M. Ang, M. O. Tade, C. E. Buckley, S. B. Wang, Chem. Eng. J. 2012, $187,415-420$.

[88] a) N. Lock, M. Christensen, Y. Wu, V. K. Peterson, M. K. Thomsen, R. O. Piltz, A. J. RamirezCuesta, G. J. McIntyre, K. Noren, R. Kutteh, C. J. Kepert, G. J. Kearley, B. B. Iversen, Dalton Trans. 2013, 42, 1996-2007; b) V. K. Peterson, C. M. Brown, Y. Liu, C. J. Kepert, J. Phys. Chem. C 2011, 115, 8851-8857.

[89] C. F. Leong, T. B. Faust, P. Turner, P. M. Usov, C. J. Kepert, R. Babarao, A. W. Thornton, D. M. D'Alessandro, Dalton Trans. 2013, 42, 9831-9839.

[90] M. B. Duriska, S. M. Neville, B. Moubaraki, K. S. Murray, C. Balde, J.-F. Létard, C. J. Kepert, S. R. Batten, ChemPlusChem 2012, 77, 616-623.

[91] A. Stock, C. Massenez, Ber. Dtsch. Chem. Ges. 1912, 45, 3539-3568.

[92] H. I. Schlesinger, H. C. Brown, J. Am. Chem. Soc. 1940, 62, 3429-3435.

[93] H. I. Schlesinger, H. C. Brown, H. R. Hoekstra, L. R. Rapp, J. Am. Chem. Soc. 1953, 75, 199204.

[94] S. J. Lippard, Progress in Inorganic Chemistry, Volume 11, John Wiley \& Sons, Inc., 1970.

[95] a) S. Orimo, Y. Nakamori, G. Kitahara, K. Miwa, N. Ohba, S. Towata, A. Züttel, J. Alloys Compd. 2005, 404-406, 427-430; b) A. Züttel, A. Borgschulte, S.-I. Orimo, Scripta Mater. 2007, 56, 823-828.

[96] R. Liu, D. Book, Int. J. Hydrogen Energy 2014, 39, 2194-2200.

[97] a) D. Ravnsbaek, Y. Filinchuk, Y. Cerenius, H. J. Jakobsen, F. Besenbacher, J. Skibsted, T. R. Jensen, Angew. Chem. Int. Ed. 2009, 48, 6659-6663; b) G. N. Kalantzopoulos, J. G. Vitillo, E. Albanese, E. Pinatel, B. Civalleri, S. Deledda, S. Bordiga, M. Baricco, B. C. Hauback, J. Alloys Compd. 2015, 615, S702-S705. 
[98] D. B. Ravnsbæk, L. H. Sørensen, Y. Filinchuk, D. Reed, D. Book, H. J. Jakobsen, F. Besenbacher, J. Skibsted, T. R. Jensen, Eur. J. Inorg. Chem. 2010, 2010, 1608-1612.

[99] D. Ravnsbæk, Y. Filinchuk, Y. Cerenius, H. J. Jakobsen, F. Besenbacher, J. Skibsted, T. R. Jensen, Angew. Chem. Int. Ed. 2009, 48, 6659-6663.

[100] S. Hino, J. E. Fonneløp, M. Corno, O. Zavorotynska, A. Damin, B. Richter, M. Baricco, T. R. Jensen, M. H. Sørby, B. C. Hauback, J. Phys. Chem. C 2012, 116, 12482-12488.

[101] J. E. Olsen, M. H. Sørby, B. C. Hauback, J. Alloys Compd. 2011, 509, L228-L231.

[102] H. Grove, L. H. Rude, T. R. Jensen, M. Corno, P. Ugliengo, M. Baricco, M. H. Sørby, B. C. Hauback, RSC Adv. 2014, 4, 4736-4742.

[103] M. B. Ley, M. Paskevicius, P. Schouwink, B. Richter, D. A. Sheppard, C. E. Buckley, T. R. Jensen, Dalton Trans. 2014, 43, 13333-13342.

[104] L. Seballos, J. Z. Zhang, E. Rönnebro, J. L. Herberg, E. H. Majzoub, J. Alloys Compd. 2009, 476, 446-450.

[105] D. A. Knight, R. Zidan, R. Lascola, R. Mohtadi, C. Ling, P. Sivasubramanian, J. A. Kaduk, S.-J. Hwang, D. Samanta, P. Jena, J. Phys. Chem. C 2013, 117, 19905-19915.

[106] E. A. Nickels, M. O. Jones, W. I. F. David, S. R. Johnson, R. L. Lowton, M. Sommariva, P. P. Edwards, Angew. Chem. Int. Ed. 2008, 47, 2817-2819.

[107] T. Jaroń, P. A. Orłowski, W. Wegner, K. J. Fijałkowski, P. J. Leszczyński, W. Grochala, Angew. Chem. Int. Ed. 2015, 54, 1236-1239.

[108] H. W. Li, E. Akiba, S. Orimo, J. Alloys Compd. 2013, 580, S292-S295.

[109] H. I. Schlesinger, H. C. Brown, A. E. Finholt, J. R. Gilbreath, H. R. Hoekstra, E. K. Hyde, J. Am. Chem. Soc. 1953, 75, 215-219.

[110] E. Rönnebro, E. H. Majzoub, J. Phys. Chem. B 2007, 111, 12045-12047.

[111] E. Jeon, Y. Cho, J. Alloys Compd. 2006, 422, 273-275.

[112] a) I. Llamas-Jansa, O. Friedrichs, M. Fichtner, E. G. Bardaji, A. Züttel, B. C. Hauback, J. Phys. Chem. C 2012, 116, 13472-13479; b) M. B. Ley, E. Roedern, T. R. Jensen, Phys. Chem. Chem. Phys. 2014, 16, 24194-24199.

[113] M. P. Pitt, M. Paskevicius, D. H. Brown, D. A. Sheppard, C. E. Buckley, J. Am. Chem. Soc. 2013, $135,6930-6941$.

[114] M. Christian, K.-F. o. Aguey-Zinsou, ACS nano 2012, 6, 7739-7751.

[115] M. Paskevicius, M. P. Pitt, C. J. Webb, D. A. Sheppard, U. Filso, E. M. Gray, C. E. Buckley, J. Phys. Chem. C 2012, 116, 15231-15240.

[116] M. Chong, A. Karkamkar, T. Autrey, S.-I. Orimo, S. Jalisatgi, C. M. Jensen, Chem. Commun. 2011, 47, 1330-1332.

[117] O. Friedrichs, F. Buchter, A. Borgschulte, A. Remhof, C. N. Zwicky, P. Mauron, M. Bielmann, A. Züttel, Acta Mater. 2008, 56, 949-954.

[118] H. W. Li, K. Kikuchi, Y. Nakamori, N. Ohba, K. Miwa, S. Towata, S. Orimo, Acta Mater. 2008, 56, 1342-1347.

[119] a) M. P. Pitt, C. J. Webb, M. Paskevicius, D. Sheptyakov, C. E. Buckley, E. M. Gray, J. Phys. Chem. C 2011, 115, 22669-22679; b) G. Severa, E. Ronnebro, C. M. Jensen, Chem. Commun. 2010, 46, 421-423; c) C. Pistidda, S. Garroni, F. Dolci, E. G. Bardají, A. Khandelwal, P. Nolis, M. Dornheim, R. Gosalawit, T. Jensen, Y. Cerenius, S. Suriñach, M. D. Baró, W. Lohstroh, M. Fichtner, J. Alloys Compd. 2010, 508, 212-215.

[120] a) J. F. Mao, Z. Wu, T. J. Chen, B. C. Weng, N. X. Xu, T. S. Huang, Z. P. Guo, H. K. Liu, D. M. Grant, G. S. Walker, X. B. Yu, J. Phys. Chem. C 2007, 111, 12495-12498; b) T. E. C. Price, D. M. Grant, V. Legrand, G. S. Walker, Int. J. Hydrogen Energy 2010, 35, 4154-4161; c) X. Yu, D. Grant, G. Walker, J. Phys. Chem. C 2009, 113, 17945-17949.

[121] a) U. Bosenberg, D. B. Ravnsbaek, H. Hagemann, V. D'Anna, C. B. Minella, C. Pistidda, W. van Beek, T. R. Jensen, R. Bormann, M. Dornheim, J. Phys. Chem. C 2010, 114, 15212-15217; b) T. Nakagawa, T. Ichikawa, N. Hanada, Y. Kojima, H. Fujii, J. Alloys Compd. 2007, 446, 306-309; c) 
F. E. Pinkerton, M. S. Meyer, G. P. Meisner, M. P. Balogh, J. J. Vajo, J. Phys. Chem. C 2007, $111,12881-12885$.

[122] J. F. Mao, Z. P. Guo, X. B. Yu, H. K. Liu, Int. J. Hydrogen Energy 2013, 38, 3650-3660.

[123] a) D. J. Siegel, C. Wolverton, V. Ozolinš, Phys. Rev. B 2007, 76, 134102; b) S.-A. Jin, Y.-S. Lee, J.-H. Shim, Y. W. Cho, J. Phys. Chem. C 2008, 112, 9520-9524; C) P. Mauron, M. Bielmann, A. Remhof, A. Züttel, J.-H. Shim, Y. W. Cho, J. Phys. Chem. C 2010, 114, 16801-16805; d) J. Purewal, S.-J. Hwang, J. Bowman, Robert C, E. Rönnebro, B. Fultz, C. Ahn, J. Phys. Chem. C 2008, 112, 8481-8485.

[124] M. Aoki, K. Miwa, T. Noritake, G. Kitahara, Y. Nakamori, S. Orimo, S. Towata, Appl. Phys. A 2005, 80, 1409-1412.

[125] J. F. Mao, Z. P. Guo, H. Y. Leng, Z. Wu, Y. H. Guo, X. B. Yu, H. K. Liu, J. Phys. Chem. C 2010, 114, 11643-11649.

[126] a) S. Garroni, C. Pistidda, M. Brunelli, G. B. M. Vaughan, S. Surinach, M. D. Baro, Scripta Mater. 2009, 60, 1129-1132; b) J. F. Mao, X. B. Yu, Z. P. Guo, H. K. Liu, Z. Wu, J. Ni, J. Alloys Compd. 2009, 479, 619-623.

[127] D. Pottmaier, C. Pistidda, E. Groppo, S. Bordiga, G. Spoto, M. Dornheim, M. Baricco, Int. J. Hydrogen Energy 2011, 36, 7891-7896.

[128] C. Pistidda, S. Garroni, C. B. Minella, F. Dolci, T. R. Jensen, P. Nolis, U. Bosenberg, Y. Cerenius, W. Lohstroh, M. Fichtner, M. D. Baro, R. Bormann, M. Dornheim, J. Phys. Chem. C 2010, 114, 21816-21823.

[129] Y. Nakamori, K. Miwa, A. Ninomiya, H. Li, N. Ohba, S.-I. Towata, A. Züttel, S.-I. Orimo, Phys. Rev. B 2006, 74, 045126.

[130] Y. Nakamori, H. W. Li, M. Matsuo, K. Miwa, S. Towata, S. Orimo, J. Phys. Chem. Solids 2008, 69, 2292-2296.

[131] M. Chong, E. Callini, A. Borgschulte, A. Zuttel, C. M. Jensen, RSC Adv. 2014, 4, 63933-63940.

[132] B. Fultz, Prog. Mater Sci. 2010, 55, 247-352.

[133] a) V. Ozolins, E. H. Majzoub, C. Wolverton, J. Am. Chem. Soc. 2009, 131, 230-237; b) J. H. Wang, J. J. Hu, Y. F. Liu, Z. T. Xiong, G. T. Wu, H. G. Pan, P. Chen, J. Mater. Chem. 2009, 19, 2141-2146.

[134] Q. Gu, L. Gao, Y. Guo, Y. Tan, Z. Tang, K. S. Wallwork, F. Zhang, X. Yu, Energy Environ. Sci. 2012, 5, 7590-7600.

[135] Z. Tang, Y. Tan, H. Wu, Q. Gu, W. Zhou, C. M. Jensen, X. Yu, Acta Mater. 2013, 61, 4787-4796.

[136] J. Mao, Z. Guo, I. P. Nevirkovets, H. K. Liu, S. X. Dou, J. Phys. Chem. C 2011, 116, 1596-1604.

[137] M. P. Pitt, P. E. Vullum, M. H. Sørby, D. Blanchard, M. P. Sulic, H. Emerich, M. Paskevicius, C. E. Buckley, J. Walmsley, R. Holmestad, B. C. Hauback, J. Alloys Compd. 2012, 513, 597-605.

[138] M. P. Pitt, P. E. Vullum, M. H. Sørby, H. Emerich, M. Paskevicius, C. E. Buckley, J. C. Walmsley, R. Holmestad, B. C. Hauback, J. Phys. Chem. C 2012, 116, 14205-14217.

[139] E. Callini, A. Borgschulte, C. L. Hugelshofer, A. J. Ramirez-Cuesta, A. Züttel, J. Phys. Chem. C 2013, 118, 77-84.

[140] F. Schuth, B. Bogdanovic, M. Felderhoff, Chem. Commun. 2004, 2249-2258.

[141] A. Borgschulte, R. Gremaud, Z. Lodziana, A. Zuttel, Phys. Chem. Chem. Phys. 2010, 12, 50615066.

[142] R. L. Corey, D. T. Shane, R. C. Bowman, M. S. Conradi, J. Phys. Chem. C 2008, 112, 1870618710.

[143] E. Roduner, Chem. Soc. Rev. 2006, 35, 583-592.

[144] a) K. C. Kim, B. Dai, J. K. Johnson, D. S. Sholl, Nanotechnology 2009, 20, 204001; b) S. Cheung, W.-Q. Deng, A. C. T. van Duin, W. A. Goddard, J. Phys. Chem. A 2005, 109, 851-859.

[145] a) M. Yamauchi, R. Ikeda, H. Kitagawa, M. Takata, J. Phys. Chem. C 2008, 112, 3294-3299; b) A. Pundt, R. Kirchheim, in Annu. Rev. Mater. Res., Vol. 36, 2006, pp. 555-608.

[146] A. Gutowska, L. Li, Y. Shin, C. M. Wang, X. S. Li, J. C. Linehan, R. S. Smith, B. D. Kay, B. Schmid, W. Shaw, M. Gutowski, T. Autrey, Angew. Chem. Int. Ed. 2005, 44, 3578-3582. 
[147] T. K. Nielsen, F. Besenbacher, T. R. Jensen, Nanoscale 2011, 3, 2086-2098.

[148] P. E. De Jongh, T. M. Eggenhuisen, Adv. Mater. 2013, 25, 6672-6690.

[149] A. F. Gross, J. J. Vajo, S. L. Van Atta, G. L. Olson, J. Phys. Chem. C 2008, 112, 5651-5657.

[150] a) D. T. Shane, R. L. Corey, C. McIntosh, L. H. Rayhel, R. C. Bowman, J. J. Vajo, A. F. Gross, M. S. Conradi, J. Phys. Chem. C 2010, 114, 4008-4014; b) M. H. W. Verkuijlen, P. Ngene, D. W. de Kort, C. Barre, A. Nale, E. R. H. van Eck, P. J. M. van Bentum, P. E. de Jongh, A. P. M. Kentgens, J. Phys. Chem. C 2012, 116, 22169-22178; c) X. F. Liu, E. H. Majzoub, V. Stavila, R. K. Bhakta, M. D. Allendorf, D. T. Shane, M. S. Conradi, N. Verdal, T. J. Udovic, S. J. Hwang, J. Mater. Chem. A 2013, 1, 9935-9941.

[151] a) P. S. Miedema, P. Ngene, A. M. J. van der Eerden, D. Sokaras, T.-C. Weng, D. Nordlund, Y. S. Au, F. M. F. de Groot, Phys. Chem. Chem. Phys. 2014, 16, 22651-22658; b) J. J. Vajo, Curr. Opin. Solid State Mater. Sci. 2011, 15, 52-61.

[152] P. Javadian, D. A. Sheppard, C. E. Buckley, T. R. Jensen, Nano Energy 2015, 11, 96-103.

[153] a) P. Adelhelm, K. P. de Jong, P. E. de Jongh, Chem. Commun. 2009, 6261-6263; b) P. A. Ward, J. A. Teprovich, B. Peters, J. Wheeler, R. N. Compton, R. Zidan, J. Phys. Chem. C 2013, 117, 22569-22575.

[154] Q. Lai, M. Christian, K.-F. Aguey-Zinsou, Int. J. Hydrogen Energy 2014, 39, 9339-9349.

[155] S. D. House, X. Liu, A. A. Rockett, E. H. Majzoub, I. M. Robertson, J. Phys. Chem. C 2014, 118, 8843-8851.

[156] S. Chumphongphan, U. Fils $\varnothing$, M. Paskevicius, D. A. Sheppard, T. R. Jensen, C. E. Buckley, Int. J. Hydrogen Energy 2014, 39, 11103-11109.

[157] M. Christian, K.-F. Aguey-Zinsou, Chem. Commun. 2013, 49, 6794-6796.

[158] S. G. Shore, R. W. Parry, J. Am. Chem. Soc. 1955, 77, 6084-6085.

[159] H. C. Brown, C. A. Brown, J. Am. Chem. Soc. 1962, 84, 1493-1494.

[160] a) U. Sanyal, U. B. Demirci, B. R. Jagirdar, P. Miele, ChemSusChem 2011, 4, 1731-1739; b) T. Umegaki, J.-M. Yan, X.-B. Zhang, H. Shioyama, N. Kuriyama, Q. Xu, Int. J. Hydrogen Energy 2009, 34, 2303-2311; c) H.-L. Jiang, Q. Xu, Catal. Today 2011, 170, 56-63.

[161] C. W. Yoon, P. J. Carroll, L. G. Sneddon, J. Am. Chem. Soc. 2008, 131, 855-864.

[162] a) W. V. Hough, L. J. Edwards, A. D. McElroy, J. Am. Chem. Soc. 1956, 78, 689-689; b) D. M. Goedde, G. K. Windler, G. S. Girolami, Inorg. Chem. 2007, 46, 2814-2823; c) Z. Huang, G. King, X. Chen, J. Hoy, T. Yisgedu, H. K. Lingam, S. G. Shore, P. M. Woodward, J.-C. Zhao, Inorg. Chem. 2010, 49, 8185-8187.

[163] Z. Huang, X. Chen, T. Yisgedu, E. A. Meyers, S. G. Shore, J.-C. Zhao, Inorg. Chem. 2011, 50, 3738-3742.

[164] a) Z. Huang, H. K. Lingam, X. Chen, S. Porter, A. Du, P. M. Woodard, S. G. Shore, J.-C. Zhao, RSC Adv. 2013, 3, 7460-7465; b) G. Kodama, R. W. Parry, J. Am. Chem. Soc. 1960, 82, 62506255.

[165] Z. Huang, M. Eagles, S. Porter, E. G. Sorte, B. Billet, R. L. Corey, M. S. Conradi, J.-C. Zhao, Dalton Trans. 2013, 42, 701-708.

[166] G. Kodama, R. W. Parry, J. C. Carter, J. Am. Chem. Soc. 1959, 81, 3534-3538.

[167] C. W. Yoon, L. G. Sneddon, J. Am. Chem. Soc. 2006, 128, 13992-13993.

[168] D. Schubert, D. Neiner, M. Bowden, S. Whittemore, J. Holladay, Z. Huang, T. Autrey, J. Alloys Compd., http://dx.doi.org/10.1016/i.jallcom.2015.01.063.

[169] F. Baitalow, J. Baumann, G. Wolf, K. Jaenicke-Rößler, G. Leitner, Thermochim. Acta 2002, 391, 159-168.

[170] a) A. V. Safronov, S. S. Jalisatgi, H. B. Lee, M. F. Hawthorne, Int. J. Hydrogen Energy 2011, 36, 234-239; b) C. W. Hamilton, R. T. Baker, A. Staubitz, I. Manners, Chem. Soc. Rev. 2009, 38, 279-293.

[171] H. Schlesinger, A. B. Burg, J. Am. Chem. Soc. 1938, 60, 290-299.

[172] A. G. Myers, B. H. Yang, K. J. David, Tetrahedron Lett. 1996, 37, 3623-3626. 
[173] Z. Xiong, C. K. Yong, G. Wu, P. Chen, W. Shaw, A. Karkamkar, T. Autrey, M. O. Jones, S. R. Johnson, P. P. Edwards, Nature Materials 2008, 7, 138-141.

[174] H. Wu, W. Zhou, T. Yildirim, J. Am. Chem. Soc. 2008, 130, 14834-14839.

[175] G. Lussac, L. J. Thernard, Ann. Phys. 1809, L, 32.

[176] A. W. Titherley, J. Chem. Soc. 1894, 65, 504-522.

[177] F. W. Bergstrom, W. C. Fernelius, Chem. Rev. 1933, 12, 43-179.

[178] F. W. Dafert, R. Miklauz, Monatsh. Chem. 1910, 31, 981-996.

[179] P. Chen, Z. Xiong, J. Luo, J. Lin, K. L. Tan, Nature 2002, 420, 302-304.

[180] J. Wang, T. Liu, G. Wu, W. Li, Y. Liu, C. M. Araújo, R. H. Scheicher, A. Blomqvist, R. Ahuja, Z. Xiong, P. Yang, M. Gao, H. Pan, P. Chen, Angew. Chem. Int. Ed. 2009, 48, 5828-5832.

[181] B.-X. Dong, J. Ge, Y.-L. Teng, J.-J. Gao, L. Song, J. Mater. Chem. A 2015, 3, 905-911.

[182] J. H. Yao, C. Shang, K. F. Aguey-Zinsou, Z. X. Guo, J. Alloys Compd. 2007, 432, 277-282.

[183] L. E. Klebanoff, J. O. Keller, Int. J. Hydrogen Energy 2013, 38, 4533-4576.

[184] Y. H. Hu, E. Ruckenstein, J. Phys. Chem. A 2003, 107, 9737-9739.

[185] a) P. Chen, Z. Xiong, J. Luo, J. Lin, K. L. Tan, J. Phys. Chem. B 2003, 107, 10967-10970; b) J. Lu, Z. Z. Fang, H. Y. Sohn, Inorg. Chem. 2006, 45, 8749-8754.

[186] K. Hoang, A. Janotti, C. G. Van de Walle, Phys. Rev. B 2012, 85, 064115.

[187] J. W. Makepeace, M. O. Jones, S. K. Callear, P. P. Edwards, W. I. F. David, Phys. Chem. Chem. Phys. 2014, 16, 4061-4070.

[188] a) W. I. F. David, M. O. Jones, D. H. Gregory, C. M. Jewell, S. R. Johnson, A. Walton, P. P. Edwards, J. Am. Chem. Soc. 2007, 129, 1594-1601; b) G. Miceli, C. S. Cucinotta, M. Bernasconi, M. Parrinello, J. Phys. Chem. C 2010, 114, 15174-15183; c) E. Hazrati, G. Brocks, B. Buurman, R. A. de Groot, G. A. de Wijs, Phys. Chem. Chem. Phys. 2011, 13, 6043-6052.

[189] a) S. Isobe, T. Ichikawa, N. Hanada, H. Y. Leng, M. Fichtner, O. Fuhr, H. Fujii, J. Alloys Compd. 2005, 404-406, 439-442; b) T. Ichikawa, N. Hanada, S. Isobe, H. Y. Leng, H. Fujii, J. Alloys Compd. 2005, 404-406, 435-438.

[190] S. Nayebossadri, K. F. Aguey-Zinsou, Phys. Chem. Chem. Phys. 2011, 13, 17683-17688.

[191] J. Lamb, D. Chandra, W. M. Chien, D. Phanon, N. Penin, R. Černý, K. Yvon, J. Phys. Chem. C 2011, 115, 14386-14391.

[192] a) Y. Nakamori, G. Kitahara, S. Orimo, J. Power Sources 2004, 138, 309-312; b) H. Y. Leng, T. Ichikawa, S. Hino, N. Hanada, S. Isobe, H. Fujii, J. Phys. Chem. B 2004, 108, 8763-8765; c) Z. Xiong, G. Wu, J. Hu, P. Chen, Adv. Mater. 2004, 16, 1522-1525; d) W. Luo, J. Alloys Compd. 2004, 381, 284-287.

[193] Z. Xiong, J. Hu, G. Wu, P. Chen, W. Luo, K. Gross, J. Wang, J. Alloys Compd. 2005, 398, 235239.

[194] a) Y. Nakamori, G. Kitahara, K. Miwa, N. Ohba, T. Noritake, S. Towata, S. Orimo, J. Alloys Compd. 2005, 404-406, 396-398; b) Z. Xiong, G. Wu, J. Hu, P. Chen, W. Luo, J. Wang, J. Alloys Compd. 2006, 417, 190-194; c) J. Hu, M. Fichtner, Chem. Mater. 2009, 21, 3485-3490.

[195] J. Wang, G. Wu, Y. S. Chua, J. Guo, Z. Xiong, Y. Zhang, M. Gao, H. Pan, P. Chen, ChemSusChem 2011, 4, 1622-1628.

[196] a) L. Xie, J. Zheng, Y. Liu, Y. Li, X. Li, Chem. Mater. 2007, 20, 282-286; b) L. Xie, J. Zheng, Y. Liu, Y. Li, X. G. Li, Chem. Mater. 2008, 20, 282-286.

[197] G. Xia, D. Li, X. Chen, Y. Tan, Z. Tang, Z. Guo, H. Liu, Z. Liu, X. Yu, Adv. Mater. 2013, 25, 62386244.

[198] A. E. Finholt, A. C. Bond Jr, H. I. Schlesinger, J. Am. Chem. Soc. 1947, 69, 1199-1203.

[199] G. Chizinsky, G. G. Evans, T. R. P. Gibb, M. J. Rice, J. Am. Chem. Soc. 1955, 77, 3164-3165.

[200] M. Paskevicius, D. A. Sheppard, C. E. Buckley, J. Alloys Compd. 2009, 487, 370-376.

[201] M. Paskevicius, J. Webb, M. P. Pitt, T. P. Blach, B. C. Hauback, E. M. Gray, C. E. Buckley, J. Alloys Compd. 2009, 481, 595-599. 
[202] a) N. M. Alpatova, T. N. Dymova, Y. N. Y.M. Kessler, O. R. O.R. Osipov, Russ. Chem. Rev. 1968, 37, 99; b) H. Clasen, Vol. Ger. Pat. 1141623 1962; c) R. Zidan, B. L. Garcia-Diaz, C. S. Fewox, A. C. Stowe, J. R. Gray, A. G. Harter, Chem. Commun. 2009, 3717-3719.

[203] a) E. C. Ashby, J. Am. Chem. Soc. 1964, 86, 1882-1883; b) K. N. II N Semenenko, B. M. Bulychev, E. A. Shevlyagina, Russ. Chem. Rev. 1966, 35, 649; c) J. Graetz, S. Chaudhuri, J. Wegrzyn, Y. Celebi, J. R. Johnson, W. Zhou, J. J. Reilly, J. Phys. Chem. C 2007, 111, 1914819152; d) D. Lacina, J. Wegrzyn, J. Reilly, Y. Celebi, J. Graetz, Energy Environ. Sci. 2010, 3, 1099-1105.

[204] L. Dinh, D. Knight, M. Paskevicius, C. Buckley, R. Zidan, Appl. Phys. A 2012, 107, 173-181.

[205] A. Zaluska, L. Zaluski, J. O. Ström-Olsen, J. Alloys Compd. 2000, 298, 125-134.

[206] T. N. Dymova, N. G. Eliseeva, S. I. Bakum, Y. M. Dergachev, Dokl. Akad. Nauk SSSR 1974, 215, 1369.

[207] a) C. M. Jensen, K. J. Gross, Appl. Phys. A 2001, 72, 213-219; b) P. Wang, C. M. Jensen, J. Phys. Chem. B 2004, 108, 15827-15829.

[208] a) R. A. Zidan, S. Takara, A. G. Hee, C. M. Jensen, J. Alloys Compd. 1999, 285, 119-122; b) S. S. Srinivasan, H. W. Brinks, B. C. Hauback, D. Sun, C. M. Jensen, J. Alloys Compd. 2004, 377, 283-289.

[209] a) B. Bogdanović, M. Felderhoff, S. Kaskel, A. Pommerin, K. Schlichte, F. Schüth, Adv. Mater. 2003, 15, 1012-1015; b) M. Fichtner, O. Fuhr, O. Kircher, J. Rothe, Nanotechnology 2003, 14, 778-785; c) B. Bogdanović, M. Felderhoff, A. Pommerin, F. Schüth, N. Spielkamp, Adv. Mater. 2006, 18, 1198-1201; d) A. Fossdal, H. W. Brinks, J. E. Fonneløp, B. C. Hauback, J. Alloys Compd. 2005, 397, 135-139.

[210] a) M. Felderhoff, K. Klementiev, W. Grunert, B. Spliethoff, B. Tesche, J. M. Bellosta von Colbe, B. Bogdanovic, M. Hartel, A. Pommerin, F. Schuth, C. Weidenthaler, Phys. Chem. Chem. Phys. 2004, 6, 4369-4374; b) A. Léon, O. Kircher, J. Rothe, M. Fichtner, J. Phys. Chem. B 2004, 108, 16372-16376.

[211] K. J. Michel, V. Ozoliňš, J. Phys. Chem. C 2011, 115, 21454-21464.

[212] a) T. M. Ivancic, S.-J. Hwang, R. C. Bowman, D. S. Birkmire, C. M. Jensen, T. J. Udovic, M. S. Conradi, J. Phys. Chem. Lett. 2010, 1, 2412-2416; b) E. G. Sorte, R. C. Bowman, E. H. Majzoub, M. H. W. Verkuijlen, T. J. Udovic, M. S. Conradi, J. Phys. Chem. C 2013, 117, 8105-8113.

[213] Q. J. Fu, A. J. Ramirez-Cuesta, S. C. Tsang, J. Phys. Chem. B 2005, 110, 711-715.

[214] J. M. Bellosta von Colbe, W. Schmidt, M. Felderhoff, B. Bogdanović, F. Schüth, Angew. Chem. Int. Ed. 2006, 45, 3663-3665.

[215] K. J. Michel, V. Ozolinš, MRS Bull. 2013, 38, 462-472.

[216] a) T. A. Johnson, S. W. Jorgensen, D. E. Dedrick, Faraday Discuss. 2011, 151, 327-352; b) J. M. Bellosta von Colbe, O. Metz, G. A. Lozano, P. K. Pranzas, H. W. Schmitz, F. Beckmann, A. Schreyer, T. Klassen, M. Dornheim, Int. J. Hydrogen Energy 2012, 37, 2807-2811.

[217] J. R. Ares Fernandez, F. Aguey-Zinsou, M. Elsaesser, X. Z. Ma, M. Dornheim, T. Klassen, R. Bormann, Int. J. Hydrogen Energy 2007, 32, 1033-1040.

[218] E. C. Ashby, G. J. Brendel, H. E. Redman, Inorg. Chem. 1963, 2, 499-504.

[219] a) J. Wang, A. D. Ebner, J. A. Ritter, J. Am. Chem. Soc. 2006, 128, 5949-5954; b) J. Graetz, J. Wegrzyn, J. J. Reilly, J. Am. Chem. Soc. 2008, 130, 17790-17794.

[220] a) X. Liu, G. S. McGrady, H. W. Langmi, C. M. Jensen, J. Am. Chem. Soc. 2009, 131, 50325033; b) X. Liu, H. W. Langmi, S. D. Beattie, F. F. Azenwi, G. S. McGrady, C. M. Jensen, J. Am. Chem. Soc. 2011, 133, 15593-15597.

[221] T. D. Humphries, D. Birkmire, B. C. Hauback, G. Sean McGrady, C. M. Jensen, Phys. Chem. Chem. Phys. 2013, 15, 6179-6181.

[222] J. Graetz, Y. Lee, J. J. Reilly, S. Park, T. Vogt, Phys. Rev. B 2005, 71, 184115.

[223] a) M. Christian, K.-F. Aguey-Zinsou, Nanoscale 2010, 2, 2587-2590; b) C. P. Baldé, B. P. C. Hereijgers, J. H. Bitter, K. P. d. Jong, J. Am. Chem. Soc. 2008, 130, 6761-6765.

[224] M. A. Wahab, J. N. Beltramini, Int. J. Hydrogen Energy 2014, 39, 18280-18290. 
[225] J. Gao, P. Adelhelm, M. H. W. Verkuijlen, C. Rongeat, M. Herrich, P. J. M. van Bentum, O. Gutfleisch, A. P. M. Kentgens, K. P. de Jong, P. E. de Jongh, J. Phys. Chem. C 2010, 114, 46754682.

[226] W. Lohstroh, A. Roth, H. Hahn, M. Fichtner, ChemPhysChem 2010, 11, 789-792.

[227] a) R. Urbanczyk, K. Peinecke, M. Felderhoff, K. Hauschild, W. Kersten, S. Peil, D. Bathen, Int. J. Hydrogen Energy 2014, 39, 17118-17128; b) M. Y. Yan, F. Sun, X. P. Liu, J. H. Ye, H. P. Yuan, S. M. Wang, L. J. Jiang, J. Alloys Compd. 2014, 603, 19-22.

[228] a) S. Garrier, B. Delhomme, P. de Rango, P. Marty, D. Fruchart, S. Miraglia, Int. J. Hydrogen Energy 2013, 38, 9766-9771; b) P. Marty, P. de Rango, B. Delhomme, S. Garrier, J. Alloys Compd. 2013, 580, S324-S328; c) S. Garrier, A. Chaise, P. de Rango, P. Marty, B. Delhomme, D. Fruchart, S. Miraglia, Int. J. Hydrogen Energy 2011, 36, 9719-9726.

[229] a) D. N. Harries, M. Paskevicius, D. A. Sheppard, T. Price, C. E. Buckley, Proceedings of the IEEE 2012, 100, 539-549; b) M. Fellet, C. E. Buckley, M. Paskevicius, D. A. Sheppard, MRS Bull. 2013, 38, 1012-1013.

[230] Fichtner, The World Bank and ESMAP, Washington D.C., 2010.

[231] M. Felderhoff, B. Bogdanović, Int. J. Mol. Sci. 2009, 10, 325-344.

[232] S. Chumphongphan, M. Paskevicius, D. A. Sheppard, C. E. Buckley, Int. J. Hydrogen Energy 2013, 38, 2325-2331.

[233] a) P. S. Rudman, J. Less Comm. Met. 1983, 89, 93-110; b) P. S. Rudman, G. D. Sandrock, P. D. Goodell, J. Less Comm. Met. 1983, 89, 437-446; c) J. J. Sheridan lii, F. G. Eisenberg, E. J. Greskovich, G. D. Sandrock, E. L. Huston, J. Less Comm. Met. 1983, 89, 447-455.

[234] G. Sandrock, S. Suda, L. Schlapbach, in Hydrogen in Intermetallic Compounds II (Ed.: L. Schlapbach), Springer-Verlag, New York, USA, 1992.

[235] a) M. Groll, W. Supper, U. Mayer, O. Brost, Int. J. Hydrogen Energy 1987, 12, 89-97; b) E. Tuscher, P. Weinzierl, O. J. Eder, Int. J. Hydrogen Energy 1983, 8, 199-203.

[236] D. N. Harries, M. Paskevicius, D. A. Sheppard, T. E. C. Price, C. E. Buckley, Proceedings of the IEEE 2012, 100, 539-549.

[237] G. Sandrock, G. Thomas, IEA/DOE/SNL Hydride Databases.

[238] M. Groll, A. Isselhorst, M. Wierse, Int. J. Hydrogen Energy 1994, 19, 507-515.

[239] K. A. Johnson, Vehicle Projects LLC, 2006.

[240] H. Furukawa, N. Ko, Y. B. Go, N. Aratani, S. B. Choi, E. Choi, A. O. Yazaydin, R. Q. Snurr, M. O'Keeffe, J. Kim, O. M. Yaghi, Science 2010, 329, 424-428.

[241] D. Yuan, D. Zhao, D. Sun, H.-C. Zhou, Angew. Chem. Int. Ed. 2010, 49, 5357-5361.

[242] T. K. Kim, M. P. Suh, Chem. Commun. 2011, 47, 4258-4260.

[243] Y. E. Cheon, M. P. Suh, Chem. Commun. 2009, 2296-2298.

[244] M. Xue, G. Zhu, Y. Li, X. Zhao, Z. Jin, E. Kang, S. Qiu, Cryst. Growth Des. 2008, 8, 2478-2483.

[245] K. S. Park, Z. Ni, A. P. Cote, J. Y. Choi, R. Huang, F. J. Uribe-Romo, H. K. Chae, M. O'Keeffe, O. M. Yaghi, P. Natl. Acad. Sci. USA 2006, 103, 10186-10191.

[246] K. Sumida, C. M. Brown, Z. R. Herm, S. Chavan, S. Bordiga, J. R. Long, Chem. Commun. 2011, 47, 1157-1159.

[247] H. I. Schlesinger, A. B. Burg, Chem. Rev. 1942, 31, 1-41.

[248] H. Schlesinger, H. C. Brown, H. R. Hoekstra, L. R. Rapp, J. Am. Chem. Soc. 1953, 75, 199-204.

[249] G. L. Soloveichik, Material Matters 2007, 2, 11-15.

[250] H. Schlesinger, H. C. Brown, J. Am. Chem. Soc. 1940, 62, 3429-3435.

[251] A. Züttel, S. Rentsch, P. Fischer, P. Wenger, P. Sudan, P. Mauron, C. Emmenegger, J. Alloys Compd. 2003, 356, 515-520.

[252] W. D. Davis, L. Mason, G. Stegeman, J. Am. Chem. Soc. 1949, 71, 2775-2781.

[253] N. Webbook.

[254] K. Miwa, N. Ohba, S.-I. Towata, Y. Nakamori, S.-I. Orimo, Phys. Rev. B 2004, 69, 245120.

[255] M. Au, A. R. Jurgensen, W. A. Spencer, D. L. Anton, F. E. Pinkerton, S.-J. Hwang, C. Kim, R. C. Bowman Jr, J. Phys. Chem. C 2008, 112, 18661-18671. 
[256] P. Mauron, F. Buchter, O. Friedrichs, A. Remhof, M. Bielmann, C. N. Zwicky, A. Züttel, J. Phys. Chem. B 2008, 112, 906-910.

[257] H. I. Schlesinger, H. C. Brown, B. Abraham, A. Bond, N. Davidson, A. Finholt, J. R. Gilbreath, H. Hoekstra, L. Horvitz, E. K. Hyde, J. Am. Chem. Soc. 1953, 75, 186-190.

[258] O. Knacke, O. Kubaschewski, K. Hesselmann, Springer, Berlin 1991.

[259] L. Klebanoff, Hydrogen storage technology: materials and applications, CRC Press, 2012.

[260] B. B. L. LaversenneE, B. Bonnetot, Entropy 2005, 184, 183.183-242.183.

[261] A. B. Burg, H. Schlesinger, J. Am. Chem. Soc. 1940, 62, 3425-3429.

[262] E. Wiberg, R. Z. Bauer, Z. Naturforsch. 1950, 5b, 397.

[263] J. Plešek, S. Heřmánek, Collect. Czech. Chem. Commun. 1966, 31, 3845-3858.

[264] V. N. Konoplev, V. M. Bakulina, Izv. Akad. Nauk SSSR. Ser. Khim. 1971, 159.

[265] P. Zanella, L. Crociani, N. Masciocchi, G. Giunchi, Inorg. Chem. 2007, 46, 9039-9041.

[266] T. Matsunaga, F. Buchter, P. Mauron, M. Bielman, Y. Nakamori, S. Orimo, N. Ohba, K. Miwa, S. Towata, A. Züttel, J. Alloys Compd. 2008, 459, 583-588.

[267] H.-W. Li, K. Kikuchi, Y. Nakamori, N. Ohba, K. Miwa, S. Towata, S. Orimo, Acta Mater. 2008, 56, 1342-1347.

[268] E. Wiberg, R. Hartwimmer, Z. Naturforsch. 1955, 295.

[269] V. I. Mikheeva, L. V. Titov, Zh. Neorg. Khim. 1964, 789.

[270] K. Miwa, M. Aoki, T. Noritake, N. Ohba, Y. Nakamori, S.-I. Towata, A. Züttel, S.-I. Orimo, Phys. Rev. B 2006, 74, 155122.

[271] J. Mao, Z. Guo, C. K. Poh, A. Ranjbar, Y. Guo, X. Yu, H. Liu, J. Alloys Compd. 2010, 500, 200205.

[272] R. Varin, L. Zbroniec, M. Polanski, Y. Filinchuk, R. Cerny, Int. J. Hydrogen Energy 2012, 37, 16056-16069.

[273] B. Richter, D. B. Ravnsbaek, N. Tumanov, Y. Filinchuk, T. R. Jensen, Dalton Trans. 2015, 44, 3988-3996.

[274] P. Choudhury, V. R. Bhethanabotla, E. Stefanakos, J. Phys. Chem. C 2009, 113, 13416-13424.

[275] H. Schlesinger, R. T. Sanderson, A. Burg, J. Am. Chem. Soc. 1940, 62, 3421-3425.

[276] J. B. Hinkamp, V. Hnizda, Ind. Eng. Chem. 1955, 47, 1560-1562.

[277] T. J. Marks, J. R. Kolb, Chem. Rev. 1977, 77, 263-293.

[278] H. Hoekstra, J. Katz, J. Am. Chem. Soc. 1949, 71, 2488-2492.

[279] V. V. Volkov, K. G. Myakishev, Konoplev, V. N.; Bakulina, V. M. 1987, 1429.

[280] a) K. N. Semenenko, O. V. Kravchenko, V. Polyakova, Russ. Chem. Rev. 1973, 42, 1-13; b) W. Reid, J. Bish, A. Brenner, J. Electrochem. Soc. 1957, 104, 21-29.

[281] F. Gennari, L. Fernández Albanesi, I. Rios, Inorg. Chim. Acta 2009, 362, 3731-3737.

[282] T. Sato, K. Miwa, Y. Nakamori, K. Ohoyama, H.-W. Li, T. Noritake, M. Aoki, S.-i. Towata, S.-i. Orimo, Phys. Rev. B 2008, 77, 104114.

[283] A. Remhof, A. Borgschulte, O. Friedrichs, P. Mauron, Y. Yan, A. Züttel, Scripta Mater. 2012, 66, 280-283.

[284] Y. Yan, H.-W. Li, T. Sato, N. Umeda, K. Miwa, S.-i. Towata, S.-i. Orimo, Int. J. Hydrogen Energy 2009, 34, 5732-5736.

[285] Y.-S. Lee, J.-H. Shim, Y. W. Cho, J. Phys. Chem. C 2010, 114, 12833-12837.

[286] E. A. Nickels, M. O. Jones, W. I. David, S. R. Johnson, R. L. Lowton, M. Sommariva, P. P. Edwards, Angew. Chem. Int. Ed. 2008, 47, 2817-2819.

[287] M. Au, M. J. Meziani, Y.-P. Sun, F. E. Pinkerton, J. Phys. Chem. C 2011, 115, 20765-20773.

[288] Z.-Z. Fang, X.-D. Kang, P. Wang, H.-W. Li, S.-I. Orimo, J. Alloys Compd. 2010, 491, L1.

[289] J. Y. Lee, D. Ravnsbæk, Y.-S. Lee, Y. Kim, Y. Cerenius, J.-H. Shim, T. R. Jensen, N. H. Hur, Y. W. Cho, J. Phys. Chem. C 2009, 113, 15080-15086.

[290] Z.-Z. Fang, X.-D. Kang, J.-H. Luo, P. Wang, H.-W. Li, S.-I. Orimo, J. Phys. Chem. C 2010, 114, 22736-22741. 
[291] H.-W. Li, S.-i. Orimo, Y. Nakamori, K. Miwa, N. Ohba, S. Towata, A. Züttel, J. Alloys Compd. 2007, 446, 315-318.

[292] a) C. Kim, S.-J. Hwang, R. C. Bowman Jr, J. W. Reiter, J. A. Zan, J. G. Kulleck, H. Kabbour, E. Majzoub, V. Ozolins, J. Phys. Chem. C 2009, 113, 9956-9968; b) H. Hagemann, M. Longhini, J. W. Kaminski, T. A. Wesolowski, R. Cerny, N. Penin, M. H. Sørby, B. C. Hauback, G. Severa, C. M. Jensen, J. Phys. Chem. A 2008, 112, 7551-7555.

[293] R. Černý, G. Severa, D. B. Ravnsbæk, Y. Filinchuk, V. D’Anna, H. Hagemann, D. r. Haase, C. M. Jensen, T. R. Jensen, J. Phys. Chem. C 2009, 114, 1357-1364.

[294] M. Chong, E. Callini, A. Borgschulte, A. Züttel, C. M. Jensen, RSC Adv. 2014, 4, 63933-63940.

[295] D. Ravnsbæk, Y. Filinchuk, Y. Cerenius, H. J. Jakobsen, F. Besenbacher, J. Skibsted, T. R. Jensen, Angew. Chem. Int. Ed. 2009, 121, 6787-6791.

[296] R. Černý, P. Schouwink, Y. Sadikin, K. Stare, L. u. Smrčok, B. Richter, T. R. Jensen, Inorg. Chem. 2013, 52, 9941-9947.

[297] T. Jaroń, W. Wegner, K. J. Fijałkowski, P. J. Leszczyński, W. Grochala, Chemistry-A European Journal 2015.

[298] L. Seballos, J. Z. Zhang, E. Rönnebro, J. L. Herberg, E. Majzoub, J. Alloys Compd. 2009, 476, 446-450.

[299] G. Severa, H. Hagemann, M. s. Longhini, J. W. Kaminski, T. A. Wesolowski, C. M. Jensen, J. Phys. Chem. C 2010, 114, 15516-15521.

[300] G. Xia, Q. Gu, Y. Guo, X. Yu, J. Mater. Chem. 2012, 22, 7300-7307.

[301] R. Černý, D. B. Ravnsbæk, G. Severa, Y. Filinchuk, V. D’Anna, H. Hagemann, D. r. Haase, J. Skibsted, C. M. Jensen, T. R. Jensen, J. Phys. Chem. C 2010, 114, 19540-19549.

[302] P. Schouwink, V. D’Anna, M. B. Ley, L. v. M. Lawson Daku, B. Richter, T. R. Jensen, H. Hagemann, R. Černý, J. Phys. Chem. C 2012, 116, 10829-10840.

[303] I. Dovgaliuk, V. Ban, Y. Sadikin, R. Černý, L. Aranda, N. Casati, M. Devillers, Y. Filinchuk, J. Phys. Chem. C 2013, 118, 145-153.

[304] E. Roedern, T. R. Jensen, J. Phys. Chem. C 2014, 118, 23567-23574.

[305] a) M. Au, A. Jurgensen, J. Phys. Chem. B 2006, 110, 7062-7067; b) G. L. Xia, Y. H. Guo, Z. Wu, X. B. Yu, J. Alloys Compd. 2009, 479, 545-548.

[306] a) J. Yang, A. Sudik, C. Wolverton, J. Phys. Chem. C 2007, 111, 19134-19140; b) U. Bösenberg, S. Doppiu, L. Mosegaard, G. Barkhordarian, N. Eigen, A. Borgschulte, T. R. Jensen, Y. Cerenius, O. Gutfleisch, T. Klassen, Acta Mater. 2007, 55, 3951-3958; c) G. Barkhordarian, T. Klassen, M. Dornheim, R. Bormann, J. Alloys Compd. 2007, 440, L18-L21; d) V. Ozolins, E. Majzoub, C. Wolverton, J. Am. Chem. Soc. 2008, 131, 230-237; e) S. V. Alapati, J. K. Johnson, D. S. Sholl, J. Phys. Chem. B 2006, 110, 8769-8776; f) S. Alapati, J. Johnson, D. Sholl, J. Phys. Chem. C 2008, 112(14), 5258-5262; g) X. Wan, T. Markmaitree, W. Osborn, L. L. Shaw, J. Phys. Chem. C 2008, 112, 18232-18243; h) G. S. Walker, D. M. Grant, T. C. Price, X. Yu, V. Legrand, J. Power Sources 2009, 194, 1128-1134; i) S. Sabitu, A. Goudy, J. Phys. Chem. C 2012, 116, 13545-13550; j) Y. Yan, H.-W. Li, H. Maekawa, K. Miwa, S.-I. Towata, S.-I. Orimo, J. Phys. Chem. C 2011, 115, 19419-19423; k) U. Bösenberg, D. B. Ravnsbæk, H. Hagemann, V. D’Anna, C. B. Minella, C. Pistidda, W. Van Beek, T. R. Jensen, R. d. Bormann, M. Dornheim, J. Phys. Chem. C 2010, 114, 15212-15217.

[307] P.-J. Wang, Z.-Z. Fang, L.-P. Ma, X.-D. Kang, P. Wang, Int. J. Hydrogen Energy 2010, 35, 30723075.

[308] A. Züttel, P. Wenger, S. Rentsch, P. Sudan, P. Mauron, C. Emmenegger, J. Power Sources 2003, 118, 1-7.

[309] M. Au, W. Spencer, A. Jurgensen, C. Zeigler, J. Alloys Compd. 2008, 462, 303-309.

[310] a) J. Mao, Z. Guo, H. Liu, X. Yu, J. Alloys Compd. 2009, 487, 434-438; b) X.-D. Kang, P. Wang, L.-P. Ma, H.-M. Cheng, Appl. Phys. A 2007, 89, 963-966; c) O. Friedrichs, J. Kim, A. Remhof, F. Buchter, A. Borgschulte, D. Wallacher, Y. Cho, M. Fichtner, K. Oh, A. Züttel, Phys. Chem. 
Chem. Phys. 2009, 11, 1515-1520; d) Y. Zhang, Q. Tian, J. Zhang, S.-S. Liu, L.-X. Sun, J. Phys. Chem. C 2009, 113, 18424-18430.

[311] D. Blanchard, Q. Shi, C. Boothroyd, T. Vegge, J. Phys. Chem. C 2009, 113, 14059-14066.

[312] a) B. J. Zhang, B. H. Liu, Int. J. Hydrogen Energy 2010, 35, 7288-7294; b) Y. Guo, X. Yu, L. Gao, G. Xia, Z. Guo, H. K. Liu, Energy Environ. Sci. 2010, 3, 464-469; c) B. J. Zhang, B. H. Liu, Z. P. Li, J. Alloys Compd. 2011, 509, 751-757.

[313] a) G. P. Meisner, M. L. Scullin, M. P. Balogh, F. E. Pinkerton, M. S. Meyer, J. Phys. Chem. B 2006, 110, 4186-4192; b) Y. Nakamori, A. Ninomiya, G. Kitahara, M. Aoki, T. Noritake, K. Miwa, Y. Kojima, S. I. Orimo, J. Power Sources 2006, 155, 447-455; c) F. E. Pinkerton, G. P. Meisner, M. S. Meyer, M. P. Balogh, M. D. Kundrat, J. Phys. Chem. B 2005, 109, 6-8; d) F. E. Pinkerton, M. S. Meyer, G. P. Meisner, M. P. Balogh, J. Alloys Compd. 2007, 433, 282-291; e) J. P. Singer, M. S. Meyer, R. M. Speer Jr, J. E. Fischer, F. E. Pinkerton, J. Phys. Chem. C 2009, 113, 18927-18934; f) W. Tang, G. Wu, T. Liu, A. Wee, C. Yong, Z. Xiong, A. Hor, P. Chen, Dalton Trans. 2008, 2395-2399; g) H. Wu, W. Zhou, K. Wang, T. J. Udovic, J. J. Rush, T. Yildirim, L. A. Bendersky, A. F. Gross, S. L. Van Atta, J. J. Vajo, Nanotechnology 2009, 20, 204002.

[314] Y. Zhang, Q. Tian, H. Chu, J. Zhang, L. Sun, J. Sun, Z. Wen, J. Phys. Chem. C 2009, 113, 2196421969.

[315] a) A. Sudik, J. Yang, D. Halliday, C. Wolverton, J. Phys. Chem. C 2008, 112, 4384-4390; b) J. Yang, A. Sudik, D. J. Siegel, D. Halliday, A. Drews, R. O. Carter, C. Wolverton, G. J. Lewis, J. Sachtler, J. J. Low, Angew. Chem. Int. Ed. 2008, 47, 882-887; c) A. Sudik, J. Yang, D. J. Siegel, C. Wolverton, R. O. Carter III, A. Drews, J. Phys. Chem. C 2009, 113, 2004-2013.

[316] Z.-Z. Fang, X.-D. Kang, P. Wang, Int. J. Hydrogen Energy 2010, 35, 8247-8252.

[317] a) S. Garroni, C. Milanese, A. Girella, A. Marini, G. Mulas, E. Menéndez, C. Pistidda, M. Dornheim, S. Suriñach, M. D. Baró, Int. J. Hydrogen Energy 2010, 35, 5434-5441; b) S. Garroni, C. Milanese, D. Pottmaier, G. Mulas, P. Nolis, A. Girella, R. Caputo, D. Olid, F. Teixdor, M. Baricco, J. Phys. Chem. C 2011, 115, 16664-16671.

[318] C. Milanese, S. Garroni, A. Girella, G. Mulas, V. Berbenni, G. Bruni, S. Surinach, M. D. Baró, A. Marini, J. Phys. Chem. C 2011, 115, 3151-3162.

[319] a) M. Somer, S. Acar, C. Koz, I. Kokal, P. Hoehn, R. Cardoso-Gil, U. Aydemir, L. Akselrud, J. Alloys Compd. 2010, 491, 98-105; b) Y. Bai, L.-I. Zhao, Y. Wang, X. Liu, F. Wu, C. Wu, Int. J. Hydrogen Energy 2014; c) A. V. Soloninin, O. A. Babanova, E. Y. Medvedev, A. V. Skripov, M. Matsuo, S.-I. Orimo, J. Phys. Chem. C 2014, 118, 14805-14812.

[320] X. Yu, Y. Guo, D. Sun, Z. Yang, A. Ranjbar, Z. Guo, H. Liu, S. Dou, J. Phys. Chem. C 2010, 114, 4733-4737.

[321] H.-W. Li, K. Kikuchi, Y. Nakamori, K. Miwa, S. Towata, S. Orimo, Scripta Mater. 2007, 57, 679682.

[322] G. Barkhordarian, T. R. Jensen, S. Doppiu, U. Bösenberg, A. Borgschulte, R. Gremaud, Y. Cerenius, M. Dornheim, T. Klassen, R. Bormann, J. Phys. Chem. C 2008, 112, 2743-2749.

[323] a) J.-H. Kim, J.-H. Shim, Y. W. Cho, J. Power Sources 2008, 181, 140-143; b) J.-H. Kim, S.-A. Jin, J.-H. Shim, Y. W. Cho, Scripta Mater. 2008, 58, 481-483.

[324] H. Chu, Z. Xiong, G. Wu, J. Guo, T. He, P. Chen, Dalton Trans. 2010, 39, 10585-10587.

[325] a) S. R. Johnson, W. I. F. David, D. M. Royse, M. Sommariva, C. Y. Tang, F. Fabbiani, M. O. Jones, P. P. Edwards, Chem. Asian J. 2009, 4, 849-854; b) Y. Guo, G. Xia, Y. Zhu, L. Gao, X. Yu, Chem. Commun. 2010, 46, 2599-2601; c) M. Ramzan, F. Silvearv, S. Lebègue, R. Ahuja, J. Phys. Chem. C 2011, 115, 20036-20042; d) Z. Tang, Y. Tan, Q. Gu, X. Yu, J. Mater. Chem. 2012, 22, 5312-5318.

[326] K. Wang, J.-G. Zhang, J.-S. Jiao, T. Zhang, Z.-N. Zhou, J. Phys. Chem. C 2014, 118, 8271-8279.

[327] Y. Guo, H. Wu, W. Zhou, X. Yu, J. Am. Chem. Soc. 2011, 133, 4690-4693. 
[328] a) G. Soloveichik, J.-H. Her, P. W. Stephens, Y. Gao, J. Rijssenbeek, M. Andrus, J. C. Zhao, Inorg. Chem. 2008, 47, 4290-4298; b) X. Chen, X. Yu, J. Phys. Chem. C 2012, 116, 1190011906.

[329] V. N. S. Konoplev, T. A. , Zh. Neorg. Khim 1985, 1125 - 1128.

[330] a) X. Chen, F. Yuan, Y. Tan, Z. Tang, X. Yu, J. Phys. Chem. C 2012, 116, 21162-21168; b) H. Chu, G. Wu, Z. Xiong, J. Guo, T. He, P. Chen, Chem. Mater. 2010, 22, 6021-6028.

[331] O. Kravchenko, S. Kravchenko, Zh. Obshch. Khim 1989, 59, 1935.

[332] A. B. E. Zirngiebl, W. Ger. Pat. 1959, 70, 148.

[333] Y. Guo, Y. Jiang, G. Xia, X. Yu, Chem. Commun. 2012, 48, 4408-4410.

[334] a) Y. Guo, X. Yu, W. Sun, D. Sun, W. Yang, Angew. Chem. Int. Ed. 2011, 123, 1119-1123; b) P. C. Maybury, J. C. Davis Jr, R. A. Patz, Inorg. Chem. 1969, 8, 160-161.

[335] F. Yuan, Q. Gu, X. Chen, Y. Tan, Y. Guo, X. Yu, Chem. Mater. 2012, 24, 3370-3379.

[336] W. Sun, X. Chen, Q. Gu, K. S. Wallwork, Y. Tan, Z. Tang, X. Yu, Chem. Eur. J. 2012, 18, 68256834.

[337] X. Liu, D. Peaslee, C. Z. Jost, T. F. Baumann, E. H. Majzoub, Chem. Mater. 2011, 23, 13311336.

[338] Z. Fang, P. Wang, T. Rufford, X. Kang, G. Lu, H. Cheng, Acta Mater. 2008, 56, 6257-6263.

[339] Z.-Z. Fang, X.-D. Kang, P. Wang, H.-M. Cheng, J. Phys. Chem. C 2008, 112, 17023-17029.

[340] S. Cahen, J.-B. Eymery, R. Janot, J.-M. Tarascon, J. Power Sources 2009, 189, 902-908.

[341] Y. Zhang, W.-S. Zhang, A.-Q. Wang, L.-X. Sun, M.-Q. Fan, H.-L. Chu, J.-C. Sun, T. Zhang, Int. J. Hydrogen Energy 2007, 32, 3976-3980.

[342] J. Shao, X. Xiao, X. Fan, L. Zhang, S. Li, H. Ge, Q. Wang, L. Chen, J. Phys. Chem. C 2014, 118, $11252-11260$.

[343] X. Liu, D. Peaslee, C. Jost, E. Majzoub, J. Phys. Chem. C 2010, 114, 14036-14041.

[344] P. Ngene, M. R. van Zwienen, P. E. de Jongh, Chem. Commun. 2010, 46, 8201-8203.

[345] P. Ngene, P. Adelhelm, A. M. Beale, K. P. de Jong, P. E. de Jongh, J. Phys. Chem. C 2010, 114, 6163-6168.

[346] R. Gosalawit-Utke, S. Meethom, C. Pistidda, C. Milanese, D. Laipple, T. Saisopa, A. Marini, T. Klassen, M. Dornheim, Int. J. Hydrogen Energy 2014, 39, 5019-5029.

[347] M. Fichtner, Z. Zhao-Karger, J. Hu, A. Roth, P. Weidler, Nanotechnology 2009, 20, 204029.

[348] M. A. Wahab, Y. A. Jia, D. Yang, H. Zhao, X. Yao, J. Mater. Chem. A 2013, 1, 3471-3478.

[349] A. Ampoumogli, T. Steriotis, P. Trikalitis, E. G. Bardaji, M. Fichtner, A. Stubos, G. Charalambopoulou, Int. J. Hydrogen Energy 2012, 37, 16631-16635.

[350] Z. Xiong, G. Wu, Y. S. Chua, J. Hu, T. He, W. Xu, P. Chen, Energy Environ. Sci. 2008, 1, 360363.

[351] K. J. Fijałkowski, W. Grochala, J. Mater. Chem. 2009, 19, 2043-2050.

[352] H. V. Diyabalanage, T. Nakagawa, R. P. Shrestha, T. A. Semelsberger, B. L. Davis, B. L. Scott, A. K. Burrell, W. I. David, K. R. Ryan, M. O. Jones, J. Am. Chem. Soc. 2010, 132, 11836-11837.

[353] H. V. Diyabalanage, R. P. Shrestha, T. A. Semelsberger, B. L. Scott, M. E. Bowden, B. L. Davis, A. K. Burrell, Angew. Chem. Int. Ed. 2007, 46, 8995-8997.

[354] J. Luo, X. Kang, P. Wang, Energy Environ. Sci. 2013, 6, 1018-1025.

[355] Q. Zhang, C. Tang, C. Fang, F. Fang, D. Sun, L. Ouyang, M. Zhu, J. Phys. Chem. C 2010, 114, 1709-1714.

[356] H. Wu, W. Zhou, F. E. Pinkerton, M. S. Meyer, Q. Yao, S. Gadipelli, T. J. Udovic, T. Yildirim, J. J. Rush, Chem. Commun. 2011, 47, 4102-4104.

[357] X. Kang, J. Luo, Q. Zhang, P. Wang, Dalton Trans. 2011, 40, 3799-3801.

[358] K. J. Fijalkowski, R. V. Genova, Y. Filinchuk, A. Budzianowski, M. Derzsi, T. Jaroń, P. J. Leszczyński, W. Grochala, Dalton Trans. 2011, 40, 4407-4413.

[359] a) J. Herbst, L. Hector Jr, Phys. Rev. B 2005, 72, 125120; b) Y. Song, Z. Guo, Phys. Rev. B 2006, 74, 195120; c) T. Mueller, G. Ceder, Phys. Rev. B 2006, 74, 134104. 
[360] G. Meisner, F. Pinkerton, M. Meyer, M. Balogh, M. Kundrat, J. Alloys Compd. 2005, 404, 2426.

[361] Y. Kojima, Y. Kawai, N. Ohba, J. Power Sources 2006, 159, 81-87.

[362] a) Y. H. Hu, E. Ruckenstein, Ind. Eng. Chem. Res. 2005, 44, 1510-1513; b) Y. H. Hu, E. Ruckenstein, Ind. Eng. Chem. Res. 2006, 45, 4993-4998.

[363] T. Ichikawa, S. Isobe, N. Hanada, H. Fujii, J. Alloys Compd. 2004, 365, 271-276.

[364] K. Miwa, N. Ohba, S.-I. Towata, Y. Nakamori, S.-I. Orimo, Phys. Rev. B 2005, 71, 195109.

[365] Y. Kojima, Y. Kawai, J. Alloys Compd. 2005, 395, 236-239.

[366] T. Markmaitree, R. Ren, L. L. Shaw, J. Phys. Chem. B 2006, 110, 20710-20718.

[367] W. Luo, J. Alloys Compd. 2004, 381, 284-287.

[368] Y. H. Hu, E. Ruckenstein, Ind. Eng. Chem. Res. 2004, 43, 2464-2467.

[369] Y. H. Hu, E. Ruckenstein, Ind. Eng. Chem. Res. 2003, 42, 5135-5139.

[370] Z. Xiong, G. Wu, J. Hu, P. Chen, J. Power Sources 2006, 159, 167-170.

[371] J. Lu, Z. Z. Fang, H. Y. Sohn, J. Phys. Chem. B 2006, 110, 14236-14239.

[372] Y. Kojima, M. Matsumoto, Y. Kawai, T. Haga, N. Ohba, K. Miwa, S.-I. Towata, Y. Nakamori, S.I. Orimo, J. Phys. Chem. B 2006, 110, 9632-9636.

[373] Y. Chen, C.-Z. Wu, P. Wang, H.-M. Cheng, Int. J. Hydrogen Energy 2006, 31, 1236-1240.

[374] W. Luo, S. Sickafoose, J. Alloys Compd. 2006, 407, 274-281.

[375] J. Hu, Z. Xiong, G. Wu, P. Chen, K. Murata, K. Sakata, J. Power Sources 2006, 159, 120-125.

[376] Z. Xiong, G. Wu, J. Hu, P. Chen, W. Luo, J. Wang, J. Alloys Compd. 2006, 417, 190-194.

[377] Z. Xiong, J. Hu, G. Wu, P. Chen, W. Luo, K. Gross, J. Wang, J. Alloys Compd. 2005, 398, 235239.

[378] J. Yang, A. Sudik, C. Wolverton, J. Alloys Compd. 2007, 430, 334-338.

[379] Y. Nakamori, G. Kitahara, A. Ninomiya, M. Aoki, T. Noritake, S.-I. Towata, S.-I. Orimo, Materials transactions 2005, 46, 2093.

[380] a) H. Y. Leng, T. Ichikawa, S. Hino, N. Hanada, S. Isobe, H. Fujii, J. Phys. Chem. B 2004, 108, $8763-8765 ;$ b) H. Y. Leng, T. Ichikawa, S. Isobe, S. Hino, N. Hanada, H. Fujii, J. Alloys Compd. 2005, 404, 443-447.

[381] Z. Xiong, J. Hu, G. Wu, P. Chen, J. Alloys Compd. 2005, 395, 209-212.

[382] J. Hu, Z. Xiong, G. Wu, P. Chen, K. Murata, K. Sakata, J. Power Sources 2006, 159, 116-119.

[383] Y. Liu, T. Liu, Z. Xiong, J. Hu, G. Wu, P. Chen, A. T. Wee, P. Yang, K. Murata, K. Sakata, Eur. J. Inorg. Chem. 2006, 2006, 4368-4373.

[384] Y. Liu, Z. Xiong, J. Hu, G. Wu, P. Chen, K. Murata, K. Sakata, J. Power Sources 2006, 159, 135138.

[385] S. Hino, T. Ichikawa, H. Leng, H. Fujii, J. Alloys Compd. 2005, 398, 62-66.

[386] Z. Xiong, P. Chen, G. Wu, J. Lin, K. L. Tan, J. Mater. Chem. 2003, 13, 1676-1680.

[387] K. Tokoyoda, S. Hino, T. Ichikawa, K. Okamoto, H. Fujii, J. Alloys Compd. 2007, 439, 337-341.

[388] Z. Xiong, G. Wu, J. Hu, P. Chen, J. Alloys Compd. 2007, 441, 152-156.

[389] A. Finholt, A. Bond Jr, H. Schlesinger, J. Am. Chem. Soc. 1947, 69, 1199-1203.

[390] a) B. Bulychev, P. Storozhenko, V. Fokin, Russ. Chem. Bull. 2009, 58, 1817-1823; b) J. Graetz, J. J. Reilly, J. Phys. Chem. B 2005, 109, 22181-22185; c) F. M. Brower, N. E. Matzek, P. F. Reigler, H. W. Rinn, C. B. Roberts, D. L. Schmidt, J. A. Snover, K. Terada, J. Am. Chem. Soc. 1976, 98, 2450-2453.

[391] R. Zidan, B. L. Garcia-Diaz, C. S. Fewox, A. C. Stowe, J. R. Gray, A. G. Harter, Chem. Commun. 2009, 3717-3719.

[392] J. Graetz, J. Reilly, J. Kulleck, R. Bowman, J. Alloys Compd. 2007, 446, 271-275.

[393] J. Graetz, J. Reilly, G. Sandrock, J. Johnson, W. M. Zhou, J. Wegrzyn, in Advanced Materials for Energy Conversion III: A Symposium in Honor of Drs Gary Sandrock, Louis Schlapbach, and Seijirau Suda, 2006, pp. 57-63.

[394] G. Sandrock, J. Reilly, J. Graetz, W.-M. Zhou, J. Johnson, J. Wegrzyn, J. Alloys Compd. 2006, 421, 185-189. 
[395] G. Sinke, L. Walker, F. Oetting, D. Stull, J. Phys. Chem. 1967, 47, 2759-2761.

[396] S. Orimo, Y. Nakamori, T. Kato, C. Brown, C. M. Jensen, Appl. Phys. A 2006, 83, 5-8.

[397] J. Graetz, J. J. Reilly, J. Alloys Compd. 2006, 424, 262-265.

[398] C. Wolverton, V. Ozolinšs, M. Asta, Phys. Rev. B 2004, 69, 144109.

[399] X. Ke, A. Kuwabara, I. Tanaka, Phys. Rev. B 2005, 71, 184107.

[400] A. Finholt, G. D. Barbaras, G. K. Barbaras, G. Urry, T. Wartik, H. Schlesinger, J. Inorg. Nucl. Chem. 1955, 1, 317-325.

[401] a) E. Ashby, G. Brendel, H. Redman, Inorg. Chem. 1963, 2, 499-504; b) H. Clasen, Angew. Chem. 1961, 73, 322-331.

[402] J. M. B. von Colbe, M. Felderhoff, B. Bogdanović, F. Schüth, C. Weidenthaler, Chem. Commun. 2005, 4732-4734.

[403] B. Bogdanović, R. A. Brand, A. Marjanović, M. Schwickardi, J. Tölle, J. Alloys Compd. 2000, 302, 36-58.

[404] B. Bogdanović, U. Eberle, M. Felderhoff, F. Schüth, Scripta Mater. 2007, 56, 813-816.

[405] P. Claudy, B. Bonnetot, G. Chahine, J. M. Letoffe, Thermochim. Acta 1980, 38, 75-88.

[406] E. Ashby, P. Kobetz, Inorg. Chem. 1966, 5, 1615-1617.

[407] T. Kiyobayashi, S. S. Srinivasan, D. Sun, C. M. Jensen, J. Phys. Chem. A 2003, 107, 7671-7674.

[408] T. N. Dymova, N. G. Eliseeva, S. I. Bakum, Y. M. Dergachev, Dokl. Akad. Nauk SSSR. 1974, 215, 1369.

[409] S. S. Srinivasan, H. W. Brinks, B. C. Hauback, D. Sun, C. M. Jensen, J. Alloys Compd. 2004, 377, 283-289.

[410] H. Morioka, K. Kakizaki, S.-C. Chung, A. Yamada, J. Alloys Compd. 2003, 353, 310-314.

[411] C. Qiu, S. M. Opalka, G. B. Olson, D. L. Anton, Z. Metallkd. 2006, 97, 1484-1494.

[412] T. N. Dymova, Y. M. Dergachev, V. A. Sokolov, N. A. Grechanaya, Dokl. Akad. Nauk SSSR. 1975, 591.

[413] J.-P. Bastide, B. Bonnetot, J.-M. Létoffé, P. Claudy, Mater. Res. Bull. 1981, 16, 91-96.

[414] Y. Kojima, Y. Kawai, T. Haga, M. Matsumoto, A. Koiwai, J. Alloys Compd. 2007, 441, 189-191.

[415] A. Andreasen, T. Vegge, A. S. Pedersen, J. Solid State Chem. 2005, 178, 3672-3678.

[416] R. Varin, L. Zbroniec, J. Alloys Compd. 2010, 504, 89-101.

[417] M. Mamatha, C. Weidenthaler, A. Pommerin, M. Felderhoff, F. Schüth, J. Alloys Compd. 2006, 416, 303-314.

[418] J. Block, A. Gray, Inorg. Chem. 1965, 4, 304-305.

[419] W. Garner, E. Haycock, Proc. R. Soc. London, Ser. A 1952, 211, 335-351.

[420] V. P. Balema, K. W. Dennis, V. K. Pecharsky, Chem. Commun. 2000, 1665-1666.

[421] J.-W. Jang, J.-H. Shim, Y. W. Cho, B.-J. Lee, J. Alloys Compd. 2006, 420, 286-290.

[422] J. Chen, N. Kuriyama, Q. Xu, H. T. Takeshita, T. Sakai, J. Phys. Chem. B 2001, 105, 1121411220.

[423] O. Løvvik, S. M. Opalka, H. W. Brinks, B. C. Hauback, Phys. Rev. B 2004, 69, 134117.

[424] a) T. N. Dymova, V. N. Konoplev, D. P. Aleksandrov, A. S. Sizareva, T. A. Silina, Koord. Khim. 1995, 21, 175-182; b) D. Blanchard, H. Brinks, B. Hauback, P. Norby, J. Muller, J. Alloys Compd. 2005, 404, 743-747; c) A. Andreasen, J. Alloys Compd. 2006, 419, 40-44.

[425] a) V. P. Balema, L. Balema, Phys. Chem. Chem. Phys. 2005, 7, 1310-1314; b) J. Wiench, V. Balema, V. Pecharsky, M. Pruski, J. Solid State Chem. 2004, 177, 648-653.

[426] P. Claudy, B. Bonnetot, J. Letoffe, G. Turck, Thermochim. Acta 1978, 27, 213-221.

[427] J. R. Ares, K.-F. Aguey-Zinsou, F. Leardini, I. J. Ferrer, J.-F. Fernandez, Z.-X. Guo, C. Sánchez, J. Phys. Chem. C 2009, 113, 6845-6851.

[428] M. E. Arroyo y de Dompablo, G. Ceder, J. Alloys Compd. 2004, 364, 6-12.

[429] a) E. Wiberg, Z. Naturforsch., B: Chem. Sci. 1950, 5b, 397; b) E. Wiberg, R. Bauer, Z. Naturforsch., B: Chem. Sci. 1952, 7b, 131; c) E. Wiberg, Angew. Chem. 1953, 65, 16.

[430] M. Fichtner, O. Fuhr, J. Alloys Compd. 2002, 345, 286-296. 
[431] M. Mamatha, B. Bogdanović, M. Felderhoff, A. Pommerin, W. Schmidt, F. Schüth, C. Weidenthaler, J. Alloys Compd. 2006, 407, 78-86.

[432] M. Fichtner, O. Fuhr, O. Kircher, J. Alloys Compd. 2003, 356, 418-422.

[433] Y. Kim, E.-K. Lee, J.-H. Shim, Y. W. Cho, K. B. Yoon, J. Alloys Compd. 2006, 422, 283-287.

[434] M. Fichtner, J. Engel, O. Fuhr, A. Glöss, O. Rubner, R. Ahlrichs, Inorg. Chem. 2003, 42, 70607066.

[435] W. Schwab, K. Wintersberger, Z. Naturforsch., B: Chem. Sci. 1953, 8, 690.

[436] C. Wolverton, V. Ozolinš, Phys. Rev. B 2007, 75, 064101.

[437] A. Klaveness, P. Vajeeston, P. Ravindran, H. Fjellvåg, A. Kjekshus, J. Alloys Compd. 2007, 433, 225-232.

[438] C. P. Baldé, B. P. C. Hereijgers, J. H. Bitter, K. P. de Jong, Angew. Chem. Int. Ed. 2006, 45, 3501-3503.

[439] a) C. M. Andrei, J. C. Walmsley, H. W. Brinks, R. Holmestad, S. S. Srinivasan, C. M. Jensen, B. C. Hauback, Appl. Phys. A 2005, 80, 709-715; b) C. P. Balde, H. A. Stil, A. M. J. van der Eerden, K. P. de Jong, J. H. Bitter, J. Phys. Chem. C 2007, 111, 2797-2802; c) B. Bogdanović, M. Felderhoff, S. Kaskel, A. Pommerin, K. Schlichte, F. SchüTh, Adv. Mater. 2003, 15, 1012-1015; d) B. Bogdanović, M. Felderhoff, A. Pommerin, F. Schueth, N. Spielkamp, Adv. Mater. 2006, 18, 1198-1201; e) B. Bogdanović, M. Felderhoff, A. Pommerin, F. Schüth, N. Spielkamp, A. Stark, J. Alloys Compd. 2009, 471, 383-386; f) H. W. Brinks, B. C. Hauback, S. S. Srinivasan, C. M. Jensen, J. Phys. Chem. B 2005, 109, 15780-15785; g) K. J. Gross, E. H. Majzoub, S. W. Spangler, J. Alloys Compd. 2003, 356, 423-428; h) K. J. Gross, G. J. Thomas, C. M. Jensen, J. Alloys Compd. 2002, 330, 683-690; i) C. M. Jensen, R. Zidan, N. Mariels, A. Hee, C. Hagen, Int. J. Hydrogen Energy 1999, 24, 461-465; j) A. Léon, O. Kircher, M. Fichtner, J. Rothe, D. Schild, J. Phys. Chem. B 2006, 110, 1192-1200; k) E. H. Majzoub, K. J. Gross, J. Alloys Compd. 2003, 356, 363-367; I) G. Sandrock, K. Gross, G. Thomas, J. Alloys Compd. 2002, 339, 299-308; m) D. Sun, S. S. Srinivasan, T. Kiyobayashi, N. Kuriyama, C. M. Jensen, J. Phys. Chem. B 2003, 107, 10176-10179; n) Y. Suttisawat, P. Rangsunvigit, B. Kitiyanan, N. Muangsin, S. Kulprathipanja, Int. J. Hydrogen Energy 2007, 32, 1277-1285; o) T. Vegge, Phys. Chem. Chem. Phys. 2006, 8, 4853-4861; p) J. Wang, A. D. Ebner, J. A. Ritter, Adsorption 2005, 11, 811-816; q) P. Wang, X. D. Kang, H. M. Cheng, ChemPhysChem 2005, 6, 2488-2491; r) P. Wang, X.-D. Kang, H.-M. Cheng, J. Phys. Chem. B 2005, 109, 20131-20136; s) Q. Wang, Y. Chen, C. Wu, M. Tao, Chin. Sci. Bull. 2008, 53, 1784-1788; t) C. Weidenthaler, A. Pommerin, M. Felderhoff, B. Bogdanović, F. Schüth, Phys. Chem. Chem. Phys. 2003, 5, 5149-5153.

[440] M. Fichtner, O. Fuhr, O. Kircher, J. Rothe, Nanotechnology 2003, 14, 778.

[441] R. D. Stephens, A. F. Gross, S. L. Van Atta, J. J. Vajo, F. E. Pinkerton, Nanotechnology 2009, 20, 204018.

[442] a) M. Resan, M. D. Hampton, J. K. Lomness, D. K. Slattery, Int. J. Hydrogen Energy 2005, 30, 1417-1421; b) S. Chaudhuri, J. T. Muckerman, J. Phys. Chem. B 2005, 109, 6952-6957; c) X. D. Kang, P. Wang, X. P. Song, X. D. Yao, G. Q. Lu, H. M. Cheng, J. Alloys Compd. 2006, 424, 365369.

[443] T. K. Nielsen, M. Polanski, D. Zasada, P. Javadian, F. Besenbacher, J. Bystrzycki, J. Skibsted, T. R. Jensen, ACS nano 2011, 5, 4056-4064.

[444] G. Miceli, M. Guzzo, C. Cucinotta, M. Bernasconi, J. Phys. Chem. C 2012, 116, 4311-4315.

[445] R. K. Bhakta, J. L. Herberg, B. Jacobs, A. Highley, R. Behrens Jr, N. W. Ockwig, J. A. Greathouse, M. D. Allendorf, J. Am. Chem. Soc. 2009, 131, 13198-13199.

[446] B. Bogdanović, M. Schwickardi, Appl. Phys. A 2001, 72, 221-223.

[447] V. Stavila, R. K. Bhakta, T. M. Alam, E. H. Majzoub, M. D. Allendorf, ACS nano 2012, 6, 98079817.

[448] G.-J. Lee, J.-H. Shim, Y. Whan Cho, K. Sub Lee, Int. J. Hydrogen Energy 2007, 32, 1911-1915.

[449] S. Zheng, F. Fang, G. Zhou, G. Chen, L. Ouyang, M. Zhu, D. Sun, Chem. Mater. 2008, 20, 39543958. 
[450] D. Pukazhselvan, M. Hudson, B. K. Gupta, M. A. Shaz, O. N. Srivastava, J. Alloys Compd. 2007, 439, 243-248.

[451] a) M. S. Leo Hudson, H. Raghubanshi, D. Pukazhselvan, O. N. Srivastava, Int. J. Hydrogen Energy 2010, 35, 2083-2090; b) P. A. Berseth, A. G. Harter, R. Zidan, A. Blomqvist, C. M. Araújo, R. H. Scheicher, R. Ahuja, P. Jena, Nano Lett. 2009, 9, 1501-1505.

[452] a) L. Hima Kumar, B. Viswanathan, S. Srinivasa Murthy, Int. J. Hydrogen Energy 2008, 33, 366-373; b) M. Resan, M. D. Hampton, J. K. Lomness, D. K. Slattery, Int. J. Hydrogen Energy 2005, 30, 1413-1416; c) H. W. Langmi, G. S. McGrady, X. Liu, C. M. Jensen, J. Phys. Chem. C 2010, 114, 10666-10669; d) D. Blanchard, H. W. Brinks, B. C. Hauback, P. Norby, Mater. Sci. Eng., B 2004, 108, 54-59.

[453] I. Mohamad, Z. Yue, Y. Xuebin, D. Shi Xue, Int. J. Electroactive Mater. 2013, 1, 13-22.

[454] a) Z. Li, P. Li, Q. Wan, F. Zhai, Z. Liu, K. Zhao, L. Wang, S. Lü, L. Zou, X. Qu, A. A. Volinsky, J. Phys. Chem. C 2013, 117, 18343-18352; b) d. Rafi ud, Q. Xuanhui, L. Ping, L. Zhang, M. Ahmad, J. Phys. Chem. C 2011, 115, 13088-13099; c) M. Ismail, Y. Zhao, X. B. Yu, I. P. Nevirkovets, S. X. Dou, Int. J. Hydrogen Energy 2011, 36, 8327-8334.

[455] B. Bogdanovic, A. Reiser, K. Schlichte, B. Spliethoff, B. Tesche, J. Alloys Compd. 2002, 345, 7789.

[456] A. Reiser, B. Bogdanovic, K. Schlichte, Int. J. Hydrogen Energy 2000, 25, 425-430.

[457] a) W. C. Johnson, M. F. Stubbs, A. E. Sidwell, A. Pechukas, J. Am. Chem. Soc. 1939, 61, 318329; b) C. B. Hurd, K. E. Walker, J. Am. Chem. Soc. 1931, 53, 1681-1689.

[458] a) C. L. Huffine, in Metal Hydrides (Eds.: W. M. Mueller, J. P. Blackledge, G. G. Libowitz), Academic Press, New York, 1968; b) Z. Homonnay, A. Halácsy, S. Németh, S. Nagy, K. Süvegh, J. Hayward, D. Maisonnier, in The 2nd IAEA technical Meeting on First Generation of Fusion Power Plants: Design and Technology, Vienna, Austria, 2007.

[459] T. R. P. Gibb, H. W. Kruschwitz, J. Am. Chem. Soc. 1950, 72, 5365-5369.

[460] a) D. A. Sheppard, M. Paskevicius, C. E. Buckley, Chem. Mater. 2011, 23, 4298-4300; b) D. A. Sheppard, C. Corgnale, B. Hardy, T. Motyka, R. Zidan, M. Paskevicius, C. E. Buckley, RSC Adv. 2014, 4, 26552-26562.

[461] a) G. Barkhordarian, T. Klassen, R. Bormann, J. Alloys Compd. 2004, 364, 242-246; b) K. F. Aguey-Zinsou, T. Nicolaisen, J. R. Ares Fernandez, T. Klassen, R. Bormann, J. Alloys Compd. 2007, 434-435, 738-742; c) M. P. Pitt, M. Paskevicius, C. J. Webb, D. A. Sheppard, C. E. Buckley, E. M. Gray, Int. J. Hydrogen Energy 2012, 37, 4227-4237; d) M. Paskevicius, D. A. Sheppard, C. E. Buckley, J. Am. Chem. Soc. 2010, 132, 5077-5083.

[462] a) A. Andreasen, Int. J. Hydrogen Energy 2008, 33, 7489-7497; b) A. Zaluska, L. Zaluski, J. O. Ström-Olsen, Appl. Phys. A 2001, 72, 157-165.

[463] E. Akiba, Y. Ishido, H. Hayakawa, S. Shin, K. Nomura, Z. Phys. Chem. Neue Fol. 1989, 164, 1319.

[464] a) F.-K. Hsu, C.-W. Hsu, J.-K. Chang, C.-K. Lin, S.-L. Lee, C.-E. Jiang, Int. J. Hydrogen Energy 2010, 35, 13247-13254; b) J. J. Reilly, R. H. Wiswall, Inorg. Chem. 1967, 6, 2220-2223.

[465] N. Stetson, U.S. Department of Energy, Washington, D.C., 2013. 


\section{Tables}

Table 1. Hydrogen storage properties of selected MOFs.

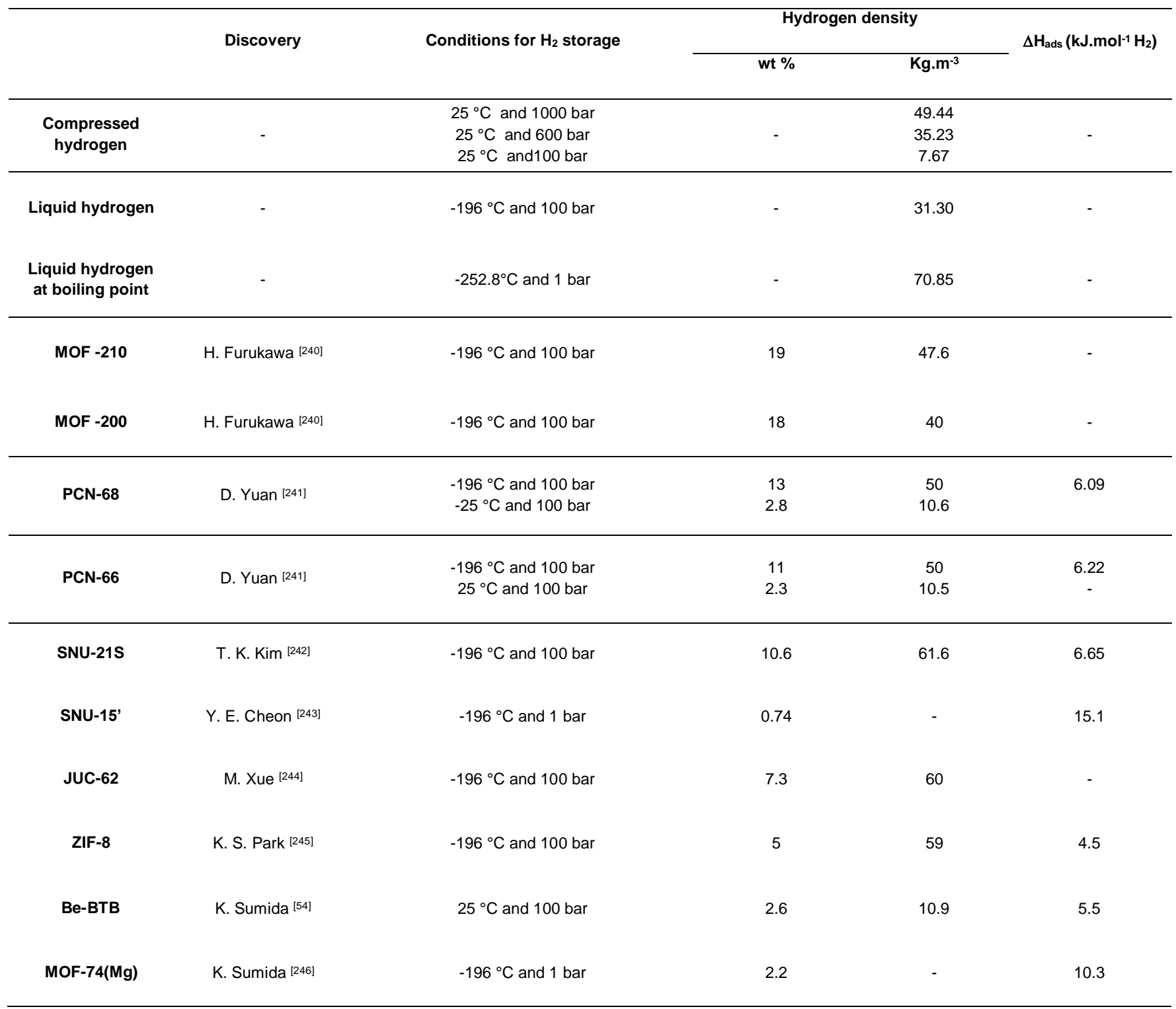


Table 2. Physical constants of boranes. ${ }^{[247]}$

\begin{tabular}{llccc}
\hline & Molecular formula & $\mathbf{H}_{2}$ density $(\mathbf{w t} \%)$ & Melting point $\left({ }^{\circ} \mathbf{C}\right)$ & Boling point $\left({ }^{\circ} \mathbf{C}\right)$ \\
\hline Diborane & $\mathrm{B}_{2} \mathrm{H}_{6}$ & 21.7 & -165.5 & -92.5 \\
Tetraborane & $\mathrm{B}_{4} \mathrm{H}_{10}$ & 18.7 & -120 & 18 \\
Stable pentaborane & $\mathrm{B}_{5} \mathrm{H}_{9}$ & 14.28 & -46.6 & 48 \\
Unstable pentaborane & $\mathrm{B}_{5} \mathrm{H}_{11}$ & 16.9 & -123 & 63 \\
Hexaborane & $\mathrm{B}_{6} \mathrm{H}_{10}$ & 13.36 & -65 & - \\
Decaborane & $\mathrm{B}_{10} \mathrm{H}_{14}$ & 11.47 & 99.7 & 213 \\
\hline
\end{tabular}


Table 3. Hydrogen storage properties of borohydrides and selected synthetic routes.

\begin{tabular}{|c|c|c|c|c|c|c|c|c|c|}
\hline & \multirow{2}{*}{ Discovery } & \multirow{2}{*}{ Synthetic routes } & \multicolumn{2}{|c|}{ Hydrogen capacity } & \multirow{2}{*}{$\mathrm{T}$ decomp. $\left({ }^{\circ} \mathrm{C}\right)$} & \multirow{2}{*}{$\begin{array}{l}\text { Reversibility } \\
\text { (T and P) }\end{array}$} & \multirow{2}{*}{$\underset{\text { (kJ.mol-1 }}{\left.\Delta \mathrm{H}_{2}\right)}$} & \multirow{2}{*}{$\begin{array}{l}-\Delta \mathrm{H}_{\text {des }} \\
\left(\mathrm{kJ} \cdot \mathrm{mol}^{-1} \mathrm{H}_{2}\right)\end{array}$} & \multirow{2}{*}{$\begin{array}{c}\Delta S \\
\left(\text { J.K-1. } \text { mol }^{-1} \mathrm{H}_{2}\right)\end{array}$} \\
\hline & & & wt \% & $\mathrm{Kg} \cdot \mathrm{m}^{-3}$ & & & & & \\
\hline $\mathrm{LiBH}_{4}$ & H. I. Schlesinger[248] & $\begin{array}{l}\left.2 \mathrm{LiH}+\mathrm{B}_{2} \mathrm{H}_{6} \rightarrow 2 \mathrm{LiBH}_{4} \text { (ethereal solvents) }\right)^{[248]} \\
\mathrm{NaBH}_{4}+\mathrm{LiCl} \rightarrow \mathrm{LiBH}_{4}+\mathrm{NaCl} \text { (ether or isopropyl } \\
\text { amine) })^{[249]}\end{array}$ & 18.5 & 112.1 & $380[250]$ & $\begin{array}{l}600^{\circ} \mathrm{C} \\
350 \text { bar }\end{array}$ & $\begin{array}{c}-146[129] \\
-177[251] \\
-184.7[252] \\
-190.46[253] \\
-194.44[21 \mathrm{a}, 251,254]\end{array}$ & $\begin{array}{l}56^{[254]} \\
68.9^{[255]} \\
74^{[256]} \\
75^{2249]}\end{array}$ & $\begin{array}{c}75.91[251] \\
100.3[255] \\
115^{[256]} \\
238[251]\end{array}$ \\
\hline $\mathrm{NaBH}_{4}$ & $\begin{array}{l}\text { H. I. Schlesinger } \\
\text { et.al[257] }\end{array}$ & $\begin{array}{l}2 \mathrm{NaH}+\mathrm{B}_{2} \mathrm{H}_{6} \rightarrow 2 \mathrm{NaBH}_{4}(\text { diglyme })^{[257]} \\
4 \mathrm{NaH}+\mathrm{B}\left(\mathrm{OCH}_{3}\right)_{3} \rightarrow \mathrm{NaBH}_{4}+3 \mathrm{NaOCH} \\
3 \\
\left(250-280^{\circ} \mathrm{C}\right)^{[249]}\end{array}$ & 10.7 & 114.5 & $400[258]$ & $\begin{array}{l}600^{\circ} \mathrm{C} \\
60 \text { bar } \\
\text { (partial) [259] }\end{array}$ & $\begin{array}{l}-182 \sim-188[129] \\
-183.3[260] \\
-191[21 a]\end{array}$ & $90[249]$ & $\begin{array}{c}101.3 \\
126.2^{[260]}\end{array}$ \\
\hline $\mathrm{KBH}_{4}$ & $\begin{array}{l}\text { H. I. Schlesinger } \\
\text { et.al[257] }\end{array}$ & $4 \mathrm{NaBH}_{4}+\mathrm{KOH} \rightarrow \mathrm{KBH}_{4}+3 \mathrm{NaOH}$ (aqueous solution) & 7.5 & 87.8 & $500^{[258]}$ & - & $\begin{array}{l}-229^{[21 a]} \\
-228[129] \\
-242.3^{[260]}\end{array}$ & - & $\begin{array}{c}106 \\
162^{[260]}\end{array}$ \\
\hline $\mathrm{Be}\left(\mathrm{BH}_{4}\right)_{2}$ & $\begin{array}{l}\text { A. B. Burg and } \mathrm{H} \text {. } \\
\text { Schlesinger }[261]\end{array}$ & $\begin{array}{l}2 \mathrm{Be}\left(\mathrm{CH}_{3}\right)_{2}+\mathrm{B}_{2} \mathrm{H}_{6} \rightarrow 2 \mathrm{Be}\left(\mathrm{BH}_{4}\right)_{2}{ }^{[261]} \\
\mathrm{BeCl} l_{2}+2 \mathrm{NaBH}_{4} \rightarrow \mathrm{Be}\left(\mathrm{BH}_{4}\right)_{2}+2 \mathrm{NaCl} \text { (vacuum distillation } \\
\left.\text { at } 1400^{\circ} \mathrm{C}\right)^{[257]}\end{array}$ & 20.8 & 146.0 & $123[261]$ & - & -108 & $27^{[249]}$ & - \\
\hline $\mathrm{Mg}\left(\mathrm{BH}_{4}\right)_{2}$ & $\begin{array}{l}\text { Wiberg, E. and } \\
\text { Bauer, R. Z. }{ }^{[262]}\end{array}$ & $\begin{array}{l}\mathrm{MgH}_{2}+\mathrm{B}_{2} \mathrm{H}_{6} \rightarrow \mathrm{Mg}\left(\mathrm{BH}_{4}\right)_{2}[263] \\
\mathrm{MgCl}_{2}+2 \mathrm{NaBH}_{4} \rightarrow \mathrm{Mg}\left(\mathrm{BH}_{4}\right)_{2}+2 \mathrm{NaCl}[264] \\
3 \mathrm{Mg}^{2}\left(\mathrm{BH}_{4}\right)_{2}+8 \mathrm{BS}\left(\mathrm{CH}_{3}\right)_{2} \rightarrow 3 \mathrm{Mg}\left(\mathrm{BH}_{4}\right)_{2} 2 \mathrm{~S}\left(\mathrm{CH}_{3}\right)_{2}+ \\
2 \mathrm{~B}\left(\mathrm{C}_{4} \mathrm{H}_{9}\right)_{3} \mathrm{~S}\left(\mathrm{CH}_{3}\right)_{2}[265]\end{array}$ & 14.9 & 147.4 & 323 & $\begin{array}{l}400^{\circ} \mathrm{C} \\
950 \text { bar [259] }\end{array}$ & $-99^{[129]}$ & $\begin{array}{l}39[266] \\
40[249] \\
57[267]\end{array}$ & $\begin{array}{c}91[266] \\
128[267]\end{array}$ \\
\hline $\mathrm{Ca}\left(\mathrm{BH}_{4}\right)_{2}$ & $\begin{array}{l}\text { E. Wiberg and R. } \\
\text { Hartwimmer [268] }\end{array}$ & $\begin{array}{l}\mathrm{CaH}_{2}+\mathrm{B}_{2} \mathrm{H}_{6} \rightarrow \mathrm{Ca}\left(\mathrm{BH}_{4}\right)_{2}[268] \\
2 \mathrm{NaBH}_{4}+\mathrm{CaX} \mathrm{CaX}_{2} \rightarrow \mathrm{Ca}\left(\mathrm{BH}_{4}\right)_{2}+2 \mathrm{NaX}(\mathrm{THF})[269] \\
\mathrm{CaB}_{6}(\mathrm{~s})+2 \mathrm{CaH}_{2}(\mathrm{~s})+10 \mathrm{H}_{2}(\mathrm{~g}) \rightarrow 3 \mathrm{Ca}\left(\mathrm{BH}_{4}\right)_{2}(\mathrm{~s})[110]\end{array}$ & 11.6 & 124.1 & $\begin{array}{c}360 \\
260^{[21 a]}\end{array}$ & $\begin{array}{l}440^{\circ} \mathrm{C} \\
700 \mathrm{bar}^{110]}\end{array}$ & $-151^{[270]}$ & $\begin{array}{l}75.5^{[249]} \\
8{ }^{[271]}\end{array}$ & $158[271]$ \\
\hline $\mathrm{Mn}\left(\mathrm{BH}_{4}\right)_{2}$ & - & $\begin{array}{l}\mathrm{LiBH}_{4}+\mathrm{MnCl}_{2} \rightarrow 0.5 \mathrm{Mn}\left(\mathrm{BH}_{4}\right)_{2}+0.5 \mathrm{Li}_{2} \mathrm{MnCl}_{4} \\
\mathrm{nLiBH} \mathrm{Mn}_{4}+\mathrm{MnCl}_{2} \rightarrow \mathrm{Mn}\left(\mathrm{BH}_{4}\right)_{2}+\mathrm{LiCl}+(\mathrm{n}-2) \mathrm{LiBH}_{4}[272]\end{array}$ & 9.5 & 117.8 & $125-175^{[273]}$ & - & $-58.89[274]$ & - & - \\
\hline $\mathrm{Al}\left(\mathrm{BH}_{4}\right)_{3}$ & H. I. Schlesinger et.al & $\begin{array}{l}\mathrm{Al}_{3}\left(\mathrm{CH}_{3}\right)_{6}+4 \mathrm{~B}_{2} \mathrm{H}_{6} \rightarrow 2 \mathrm{~B}\left(\mathrm{CH}_{3}\right)_{3}+2 \mathrm{Al}\left(\mathrm{BH}_{4}\right)_{3}[275] \\
3 \mathrm{NaBH}_{4}+\mathrm{AlCl}_{3} \rightarrow \mathrm{Al}\left(\mathrm{BH}_{4}\right)_{3}+3 \mathrm{NaCl}[276]\end{array}$ & 16.9 & 133.5 & $150^{[275]}$ & - & $-301.8^{[260]}$ & $6^{[249]}$ & $289^{[260]}$ \\
\hline $\mathrm{Zn}\left(\mathrm{BH}_{4}\right)_{3}$ & - & $\begin{array}{l}\left.2 \mathrm{NaBH}_{4}+\mathrm{ZnCl}_{2} \rightarrow \mathrm{Zn}\left(\mathrm{BH}_{4}\right)_{2}+2 \mathrm{NaCl} \text { (diethyl ether) }\right)^{*[277]} \\
2 \mathrm{NaBH}_{4}+\mathrm{ZnCl}_{2} \rightarrow \mathrm{Zn}\left(\mathrm{BH}_{4}\right)_{2}+2 \mathrm{NaCl} \text { (ball milled) }{ }^{*[111]} \\
{ }^{*} \text { no direct evidence of pure compound }\end{array}$ & 8.5 & - & 85 & - & $-18^{[129]}$ & - & - \\
\hline $\mathrm{Ti}\left(\mathrm{BH}_{4}\right)_{3}$ & $\begin{array}{l}\text { H. Hoekstra and J. } \\
\text { Katz }^{[278]}\end{array}$ & $\begin{array}{l}8 \mathrm{LiBH}_{4}+2 \mathrm{TiCl}_{4} \rightarrow 4 \mathrm{Ti}\left(\mathrm{BH}_{4}\right)_{3}+8 \mathrm{LiCl}+\mathrm{B}_{2} \mathrm{H}_{6}+\mathrm{H}_{2}[278] \\
3 \mathrm{LiBH}_{4}+\mathrm{TiCl}_{3} \rightarrow \mathrm{Ti}\left(\mathrm{BH}_{4}\right)_{3}+3 \mathrm{LiCl[279]}\end{array}$ & 13.1 & - & 25 & - & - & - & - \\
\hline $\mathrm{Zr}\left(\mathrm{BH}_{4}\right)_{4}$ & $\begin{array}{l}\text { H. Hoekstra and J. } \\
\text { Katz }\end{array}$ & $\begin{array}{l}\mathrm{NaZrF}_{5}+2 \mathrm{Al}\left(\mathrm{BH}_{4}\right)_{3} \rightarrow \mathrm{Zr}\left(\mathrm{BH}_{4}\right)_{4}+2 \mathrm{AlF}_{2}\left(\mathrm{BH}_{4}\right)+\mathrm{NaF}^{[278]} \\
\mathrm{ZrCl}_{4}+2 \mathrm{Al}\left(\mathrm{BH}_{4}\right)_{3} \rightarrow \mathrm{Zr}\left(\mathrm{BH}_{4}\right)_{4}+2 \mathrm{AlCl}_{2}\left(\mathrm{BH}_{4}\right)^{[200]} \\
\mathrm{ZrCl}{ }_{4}+4 \mathrm{NaBHH}_{4} \rightarrow \mathrm{Zr}\left(\mathrm{BH}_{4}\right)_{4}+4 \mathrm{NaCl}_{2}\left(\mathrm{ball} \text { milled) }{ }^{[281]}\right.\end{array}$ & 10.7 & 126.2 & 250 & - & $-87^{[129]}$ & - & - \\
\hline $\mathrm{Y}\left(\mathrm{BH}_{4}\right)_{3}$ & - & $\begin{array}{l}\mathrm{YCl}_{3}+3 \mathrm{LiBH}_{4} \rightarrow \mathrm{Y}\left(\mathrm{BH}_{4}\right)_{3}+3 \mathrm{LiCl}[282] \\
\mathrm{YH}_{3}+3 / 2 \mathrm{~B}_{2} \mathrm{H}_{6} \rightarrow \mathrm{Y}\left(\mathrm{BH}_{4}\right)_{3}[283] \\
\mathrm{YCl} l_{3}+3 \mathrm{LiBH}_{4} \rightarrow \mathrm{Y}\left(\mathrm{BH}_{4}\right)_{3}+3 \mathrm{LiCl[103]} \\
\mathrm{Y}\left(\mathrm{BH}_{4}\right)_{3} \mathrm{~S}\left(\mathrm{CH}_{3}\right)_{2} \rightarrow \mathrm{Y}(\mathrm{BH} 4)_{3}{ }^{[103]}\end{array}$ & 9.1 & & $187[283]$ & $\begin{array}{l}300^{\circ} \mathrm{C} \\
350 \text { bar } \\
\text { (partial) }{ }^{[284]}\end{array}$ & $-113[282]$ & $68.2^{[285]}$ & 116.2 [285] \\
\hline
\end{tabular}


Table 4. Hydrogen storage properties of a sample of existing mixed borohydrides and associated synthetic routes.

\begin{tabular}{|c|c|c|c|c|c|c|c|c|}
\hline & \multirow{2}{*}{ Synthetic method } & \multicolumn{3}{|c|}{ Hydrogen capacity (wt \%) } & \multirow{2}{*}{$\mathrm{T}$ decomp. $\left({ }^{\circ} \mathrm{C}\right)$} & \multirow{2}{*}{ T melting $\left({ }^{\circ} \mathrm{C}\right)$} & \multirow{2}{*}{$\begin{array}{l}\text { Reversibility } \\
\text { T and P }\end{array}$} & \multirow{2}{*}{ Ref. } \\
\hline & & Theoretical & Exp. & Rehydro. & & & & \\
\hline $\operatorname{LiK}\left(\mathrm{BH}_{4}\right)_{2}$ & Heating & 10.6 & - & - & 380 & 240 & - & [286] \\
\hline $\mathrm{Li}_{1.5} \mathrm{Ti}_{0.5}\left(\mathrm{BH}_{4}\right)_{3}(\mathrm{M}=\mathrm{Ti}, \mathrm{Fe}, \mathrm{Cr})^{\star}$ & Sintering & $13-15.1$ & $2.6-6$ & $3-6$ & $450-600$ & - & $\begin{array}{c}450-600{ }^{\circ} \mathrm{C}, 100-120 \\
\text { bar }\end{array}$ & [287] \\
\hline $\operatorname{LiMg}_{0.5}\left(\mathrm{BH}_{4}\right)_{2}{ }^{*}$ & Sintering & 16.3 & 5.5 & 2.5 & 500 & - & $500^{\circ} \mathrm{C}, 80$ bar & {$[287]$} \\
\hline $\mathrm{LiBH}_{4} / \mathrm{Mg}\left(\mathrm{BH}_{4}\right)_{2}$ & Ball milling & 16 & 12.5 & 2.5 & $240-500$ & 183 & $400^{\circ} \mathrm{C}, 100$ bar & {$[288]$} \\
\hline $\mathrm{Li}_{n} \mathrm{Mg}\left(\mathrm{BH}_{4}\right)_{\mathrm{y}}{ }^{*}$ & Wet & 16.3 & $16-19^{\#}$ & - & $80-500,250-500$ & - & - & [287] \\
\hline $\mathrm{LiBH}_{4} / \mathrm{Ca}\left(\mathrm{BH}_{4}\right)_{2}$ & Ball milling & $>9.6$ & 10 & 4 & $200-500$ & 200 & $400^{\circ} \mathrm{C}, 120$ bar & [289] \\
\hline $\mathrm{LiCa}\left(\mathrm{BH}_{4}\right)_{3}$ & Ball milling & - & 9.6 & 5.3 & $200-500$ & 203 & $400^{\circ} \mathrm{C}, 100 \mathrm{bar}$ & [290] \\
\hline $\mathrm{ZrLi}\left(\mathrm{BH}_{4}\right)_{5}$ & Ball milling & 11.7 & - & - & $322-600$ & - & - & [291] \\
\hline $\mathrm{ZrLi}\left(\mathrm{BH}_{4}\right)_{6}$ & Ball milling & 12.5 & - & - & $377-600$ & - & - & [291] \\
\hline \multirow{3}{*}{$\mathrm{LiSc}\left(\mathrm{BH}_{4}\right)_{4}$} & \multirow{3}{*}{ Ball milling } & 14.5 & 4.38 & - & $142-400$ & 151 & $400^{\circ} \mathrm{C}$ & [292] \\
\hline & & 6.76 & 4.38 & - & $142-262$ & 152 & - & [293] \\
\hline & & 14.5 & 4.8 & - & $80-330$ & - & $250^{\circ} \mathrm{C}, 120$ bar & [294] \\
\hline $\mathrm{LiZn}_{2}\left(\mathrm{BH}_{4}\right)_{5}$ & Ball milling/Wet & 9.5 & - & - & $121-127$ & - & - & {$[107,295]$} \\
\hline $\mathrm{Li}_{3} \mathrm{MZn}_{5}\left(\mathrm{BH}_{4}\right)_{15}$ & - & - & - & - & - & - & - & {$[296]$} \\
\hline $\mathrm{MY}\left(\mathrm{BH}_{4}\right)_{4}(\mathrm{M}=\mathrm{Li}, \mathrm{Na})$ & Wet & - & - & - & Room temp & - & - & [297] \\
\hline $\mathrm{NaK}\left(\mathrm{BH}_{4}\right)_{2}$ & Ball milling & - & - & - & - & - & - & {$[298]$} \\
\hline $\mathrm{Na}_{2} \mathrm{Mn}\left(\mathrm{BH}_{4}\right)_{4}$ & Ball milling & 10.1 & 2.9 & - & $120-150$ & - & - & [299] \\
\hline $\mathrm{NaZn}_{2}\left(\mathrm{BH}_{4}\right)_{5}$ & Ball milling & 8.8 & - & - & 95 & - & - & [295] \\
\hline $\mathrm{NaZn}\left(\mathrm{BH}_{4}\right)_{3}$ & Ball milling & 9.1 & - & - & 103 & - & - & [295] \\
\hline $\mathrm{NaZn}(\mathrm{BH} 4)_{3}$ & Wet & 9.1 & - & - & $80-200$ & - & - & {$[300]$} \\
\hline $\mathrm{NaZn}(\mathrm{BH} 4)_{3} \cdot \mathrm{NH}_{3}$ & Wet & 10.9 & $13.5^{\#}$ & - & $80-150$ & - & - & {$[300]$} \\
\hline $\mathrm{NaZn}(\mathrm{BH} 4)_{3} \cdot 2 \mathrm{NH}_{3} / \mathrm{ZnCl}_{2}$ & Wet & 10.8 & 7.9 & - & $90-160$ & - & - & {$[300]$} \\
\hline \multirow{2}{*}{$\mathrm{NaSc}\left(\mathrm{BH}_{4}\right)_{4}$} & Ball milling & 3.56 & 0.97 & - & 167 & 152 & - & [293] \\
\hline & Ball milling & - & 2.5 & - & $80-330$ & & $250^{\circ} \mathrm{C}, 120$ bar & [294] \\
\hline \multirow{2}{*}{$\mathrm{KSc}\left(\mathrm{BH}_{4}\right)_{4}$} & Ball milling & 11.1 & 4.4 & - & $187-317$ & 132 & - & [301] \\
\hline & Ball milling & 11.1 & 1.9 & - & $80-330$ & & $250^{\circ} \mathrm{C}, 120 \mathrm{bar}$ & [294] \\
\hline $\mathrm{K}_{2} \mathrm{Mg}_{\left(\mathrm{BH}_{4}\right)_{4}}$ & Ball milling & 9.9 & 5.5 & - & 150 & 143 & - & [302] \\
\hline $\mathrm{K}_{3} \mathrm{Mg}\left(\mathrm{BH}_{4}\right)_{5}$ & Ball milling & 9.3 & 3.2 & - & 191 & 195 & - & {$[302]$} \\
\hline $\mathrm{KAl}\left(\mathrm{BH}_{4}\right)_{4}$ & Ball milling & 12.7 & $20.8-32^{\#}$ & - & $135-175$ & - & - & {$[105,303]$} \\
\hline $\mathrm{K}_{2} \mathrm{Mn}\left(\mathrm{BH}_{4}\right)_{4}$ & Ball milling & - & - & - & 147 & - & - & [302] \\
\hline $\mathrm{Mn}\left(\mathrm{BH}_{4}\right)_{2} / \mathrm{MBH}_{4}(\mathrm{M}=\mathrm{Li}, \mathrm{Na}, \mathrm{Mg})$ & Ball milling & $10.1-14$ & $10.8^{\#}$ & - & $83-117$ & - & - & [304] \\
\hline $\left.\mathrm{M}\left[\left(\mathrm{Y}_{(\mathrm{BH}}\right)_{4}\right] \mathrm{(M}=\mathrm{Li}, \mathrm{Na}, \mathrm{K}, \mathrm{Cs}, \mathrm{Cs}\right)$ & Wet & - & - & - & $<350$ or unstable & - & - & [297] \\
\hline
\end{tabular}

*composition/structure is speculative

\# decomposition weight loss includes impurities 
Table 5. Summary of reported modifications on thermodynamics and kinetics of borohydrides.

\begin{tabular}{|c|c|c|c|c|c|c|c|}
\hline & \multicolumn{4}{|c|}{ Thermodynamic modifications } & \multicolumn{3}{|c|}{ Kinetics modifications } \\
\hline & Reaction path ${ }^{[305]}$ & $\begin{array}{l}\text { Reversibility } \\
\text { (T and } P)\end{array}$ & $\begin{array}{c}-\Delta \mathrm{H}_{\text {des }} \\
\left(\mathbf{k J} \cdot \mathrm{mol}^{-1} \mathrm{H}_{2}\right)\end{array}$ & $\begin{array}{c}\Delta S \\
\left(\text { J.K-1. } \mathrm{mol}^{-1} \mathrm{H}_{2}\right)\end{array}$ & Reaction path & $\begin{array}{l}\text { Reversibility } \\
\text { T and P }\end{array}$ & $\begin{array}{l}\text { Tdes and } \\
\left.\text { Des. rate (wt.min }{ }^{-1}\right)\end{array}$ \\
\hline \multirow{5}{*}{$\mathrm{LiBH}_{4}$} & $\mathrm{LiBH}_{4}+1 / 2 \mathrm{MgH}_{2} \leftrightarrow \mathrm{LiH}+1 / 2 \mathrm{MgB}_{2}+2 \mathrm{H}_{2}[38,123 \mathrm{a}, 306]$ & $\begin{array}{l}250-300^{\circ} \mathrm{C}, 50 \mathrm{bar}[3006 \mathrm{~b}] \\
350^{\circ} \mathrm{C}, 150 \mathrm{bar}[306 a] \\
350^{\circ} \mathrm{C}, 100 \mathrm{bar}[38] \\
4000^{\circ} \mathrm{C}, 75 \mathrm{bar}[307] \\
400^{\circ} \mathrm{C}, 100 \mathrm{bar}[120 \mathrm{bb}]\end{array}$ & $\begin{array}{c}40.5 \\
46.4-66.8\end{array}$ & 75 & $\begin{array}{l}\mathrm{LiBH}_{4}+\mathrm{MO}_{\mathrm{x}} \leftrightarrow \mathrm{LiMO}_{\mathrm{x}}+\mathrm{B}+2 \mathrm{H}_{2} \\
(\mathrm{M}=\mathrm{Si}, \mathrm{Ti}, \mathrm{Zr}, \mathrm{V}, \mathrm{Sn}, \mathrm{Nb}, \mathrm{Fe}, \mathrm{V})^{[120 c, 251,305 a, 308]}\end{array}$ & $\begin{array}{l}600^{\circ} \mathrm{C}, 100 \mathrm{bar}[305 \mathrm{a}] \\
600^{\circ} \mathrm{C}, 70 \mathrm{bar}{ }^{[309]}\end{array}$ & $\begin{array}{r}200-400{ }^{\circ} \mathrm{C}[308] \\
400{ }^{\circ} \mathrm{C}, 0.014[305 a] \\
100-600{ }^{\circ} \mathrm{C}, 0.009 \\
{[309]} \\
100-600^{\circ} \mathrm{C}[120 \mathrm{c}]\end{array}$ \\
\hline & $\begin{array}{l}\mathrm{LiBH}_{4}+1 / 2 \mathrm{Al} \leftrightarrow \mathrm{LiH}+1 / 2 \mathrm{AlB}_{2}+3 / 2 \mathrm{H}_{2} \\
\mathrm{LiBH}_{4}+1 / 2 \mathrm{LiAlH} \mathrm{H}_{2} \leftrightarrow 3 / 2 \mathrm{LiH}+1 / 2 \mathrm{AlB}_{2}+9 / 4 \mathrm{H}_{2}[123 \mathrm{a}, 306 \mathrm{a},\end{array}$ & $\begin{array}{l}350^{\circ} \mathrm{C}, 85 \text { bar }^{[311]} \\
350^{\circ} \mathrm{C}, 150 \mathrm{bar}^{[306 \mathrm{a}]} \\
4000^{\circ} \mathrm{C}, 100 \mathrm{bar}^{[310 \mathrm{~b}]} \\
600^{\circ} \mathrm{C}, 40 \mathrm{bar}\left[{ }^{[310 a}\right] \\
450^{\circ} \mathrm{C}, 13 \text { bar [310c] }\end{array}$ & $18.8-57.9$ & & 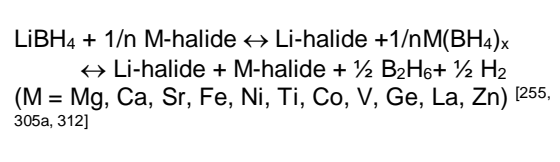 & $\begin{array}{l}3500^{\circ} \mathrm{C}, 100 \mathrm{bar}[312 b] \\
500^{\circ} \mathrm{C}, 70 \mathrm{bar}[255]\end{array}$ & $\begin{array}{l}100-600{ }^{\circ} \mathrm{C}[305 \mathrm{a}] \\
100-500^{\circ} \mathrm{C}[312 b] \\
150-450^{\circ} \mathrm{C}[255] \\
230-600^{\circ} \mathrm{C}[312 \mathrm{a}] \\
230-450^{\circ} \mathrm{C}[312 \mathrm{c}]\end{array}$ \\
\hline & 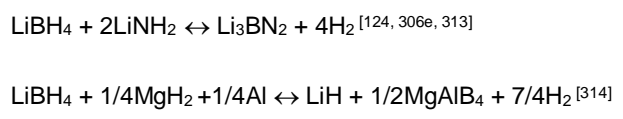 & $\begin{array}{l}300^{\circ} \mathrm{C}, 50 \text { bar }{ }^{[313 f]} \\
400^{\circ} \mathrm{C}, 40 \text { bar }{ }^{[314]}\end{array}$ & 23 & & $\begin{array}{l}\mathrm{LiBH}_{4}+\mathrm{M} \leftrightarrow \mathrm{MB}_{2}+\mathrm{LiH}+2 \mathrm{H}_{2} \\
(\mathrm{M}=\mathrm{Mg}, \mathrm{Al}, \mathrm{Sc}, \mathrm{Ti}, \mathrm{V}, \mathrm{Cr}, \mathrm{Ni})^{[305]}\end{array}$ & $\begin{array}{l}600{ }^{\circ} \mathrm{C}, 100 \mathrm{bar}[305 \mathrm{~b}] \\
350^{\circ} \mathrm{C}, 150 \mathrm{bar}[276]\end{array}$ & $\begin{array}{l}4500^{\circ} \mathrm{C}, 0.017[305 a] \\
395^{\circ} \mathrm{C}, 0.001[306 \mathrm{a}]\end{array}$ \\
\hline & $\mathrm{LiBH}_{4}+\mathrm{LiNH}_{2}+\mathrm{MgH}_{2} \leftrightarrow \mathrm{Li}_{3} \mathrm{BN}_{2}+\mathrm{Mg}_{3} \mathrm{~N}_{2}+\mathrm{LiH}+\mathrm{H}_{2}[315]$ & $180^{\circ} \mathrm{C}, 100$ bar $^{[315 b]}$ & & & $\mathrm{LiBH}_{4}+\mathrm{MO}_{\mathrm{x}}+\mathrm{M}^{\prime}$-halide $[309]$ & $600^{\circ} \mathrm{C}, 70$ bar ${ }^{[309]}$ & $\begin{array}{c}60-450^{\circ} \mathrm{C}, 0.0045 \\
{[309]}\end{array}$ \\
\hline & $\begin{array}{l}\mathrm{LiBH}_{4}+1 / \mathrm{nMH} \mathrm{MH}_{x} \stackrel{\leftrightarrow}{\mathrm{LiH}}+1 / \mathrm{n} \mathrm{MBB}+\mathrm{xH}_{2} \\
(\mathrm{M}=\mathrm{Ca}, \mathrm{Sc}, \mathrm{Ce}, \mathrm{Y}, \mathrm{Cr}, \mathrm{Ti}, \mathrm{V}, \mathrm{Fe})^{[123,306 e, 306 f]}\end{array}$ & $350-400{ }^{\circ} \mathrm{C}, 100$ bar [123b] & $34.1-66.5$ & & Graphite $[149,316]$ & $400^{\circ} \mathrm{C}, 100$ bar $[149,316]$ & $\begin{array}{l}453^{\circ} \mathrm{C}, 0.006[149] \\
450^{\circ} \mathrm{C}, 0.072[316]\end{array}$ \\
\hline $\mathrm{NaBH}_{4}$ & $\begin{array}{l}\mathrm{NaBH}_{4}+1 / 2 \mathrm{MgH}_{2} \leftrightarrow \mathrm{Na}+1 / 2 \mathrm{MgB}_{2}+5 / 2 \mathrm{H}_{2}[306 c, 317] \\
\mathrm{NaBH}_{4}+1 / 2 \mathrm{MgH}_{2}+\mathrm{M} \text {-halide } \leftrightarrow \text { Na-halide }+1 / 2 \mathrm{MgB}_{2}+ \\
5 / 2 \mathrm{H}_{2} \\
(\mathrm{M}=\mathrm{Mg}, \mathrm{Ti}, \mathrm{V}, \mathrm{Nb})[318] \\
\mathrm{NaBH}_{4}+1 / 2 \mathrm{NaNH}_{2} \leftrightarrow \mathrm{Na}_{3} \mathrm{BN}_{2}+4 \mathrm{H}_{2}[319]\end{array}$ & $\begin{array}{l}450^{\circ} \mathrm{C}, 50 \text { bar }{ }^{[317 \mathrm{a}]} \\
450^{\circ} \mathrm{C}, 60 \text { bar }{ }^{[318]}\end{array}$ & $\begin{array}{l}62 \\
-\end{array}$ & - & - & - & - \\
\hline $\mathrm{Mg}\left(\mathrm{BH}_{4}\right)_{2}$ & $\begin{array}{l}\mathrm{Mg}\left(\mathrm{BH}_{4}\right)_{2}+\mathrm{LiNH}_{2} \leftrightarrow \mathrm{Li}-\mathrm{Mg}+\mathrm{BN} \text {-related }+5 \mathrm{H}_{2}[320] \\
\mathrm{Mg}\left(\mathrm{BH}_{4}\right)_{2}+1 / 2 \mathrm{NaH} \leftrightarrow 1 / 2 \mathrm{NaMgH}_{3}+1 / 2 \mathrm{MgB}_{4}+7 / 2 \mathrm{H}_{2} \\
{[306 \mathrm{ff}]} \\
\mathrm{Mg}\left(\mathrm{BH}_{4}\right)_{2}+1 / \mathrm{n} \mathrm{MH}_{2} \leftrightarrow \mathrm{MgH}_{2}+1 / \mathrm{MBB}_{2}+\mathrm{xH}_{2} \\
(\mathrm{M}=\mathrm{Ca}, \mathrm{Sc}, \mathrm{Ti})[3066]\end{array}$ & $\begin{array}{l}- \\
-\end{array}$ & - & - & $\mathrm{Mg}\left(\mathrm{BH}_{4}\right)_{2}+\mathrm{TiCl}_{3} \leftrightarrow \mathrm{MgTi}_{x}\left(\mathrm{BH}_{4}\right)_{(2+n x)}+\mathrm{MgCl}_{2}[321]$ & - & $88-530^{\circ} \mathrm{C}[321]$ \\
\hline $\mathrm{Ca}\left(\mathrm{BH}_{4}\right)_{2}$ & $\begin{array}{l}\mathrm{Ca}\left(\mathrm{BH}_{4}\right)_{2}+\mathrm{MgH}_{2} \leftrightarrow \mathrm{CaH}_{2}+\mathrm{MgB}_{2}+4 \mathrm{H}_{2}[123 \mathrm{a}, 306 c, 322] \\
\mathrm{Ca}\left(\mathrm{BH}_{4}\right)_{2}+\mathrm{MH}_{x} \leftrightarrow \mathrm{CaH}_{2}+\mathrm{MB}_{2}+6 \mathrm{H}_{2} \\
(\mathrm{M}=\mathrm{Al}, \mathrm{Sc}, \mathrm{Ti}, \mathrm{V}, \mathrm{Cr})^{[123 a]} \\
\mathrm{Ca}\left(\mathrm{BH}_{4}\right)_{2}+\mathrm{LiNH}_{2} \leftrightarrow \mathrm{Li}-\mathrm{Ca}+\mathrm{BN} \text {-related }+5 \mathrm{H}_{2}{ }^{[324]}\end{array}$ & $350^{\circ} \mathrm{C}, 300$ bar ${ }^{[322]}$ & $45-47$ & - & $\begin{array}{l}\mathrm{Ca}\left(\mathrm{BH}_{4}\right)_{2}+\mathrm{M} \text {-halide } \leftrightarrow \text { Ca-halide }+\mathrm{MB}_{2}+\mathrm{CaB}_{6} \\
+\mathrm{CaH}_{2}+\mathrm{x} \mathrm{H}_{2}(\mathrm{M}=\mathrm{Nb}, \mathrm{Ti}){ }^{[323]}\end{array}$ & $350^{\circ} \mathrm{C}, 90$ bar $[323]$ & $320-550^{\circ} \mathrm{C}[323]$ \\
\hline
\end{tabular}


Table 6. Hydrogen storage properties of borohydrides combined with ammonia.

\begin{tabular}{|c|c|c|c|c|c|}
\hline & \multirow{2}{*}{ Discovery } & \multicolumn{2}{|c|}{ Hydrogen capacity (wt \%) } & \multirow{2}{*}{ T decomp. $\left({ }^{\circ} \mathrm{C}\right)$} & \multirow{2}{*}{ T melting $\left({ }^{\circ} \mathrm{C}\right)$} \\
\hline & & Theoretical & Exp. & & \\
\hline $\mathrm{Li}\left(\mathrm{NH}_{3}\right) \mathrm{BH}_{4}{ }^{[325]}$ & - & 15.5 & $\begin{array}{c}0^{[325 \mathrm{a}]} \\
3.6\left[6^{[325 \mathrm{~d}]}\right. \\
4^{[325 \mathrm{~b}]}\end{array}$ & $\begin{array}{r}40-160[325 a] \\
50-600[3252] \\
100-350[325]]\end{array}$ & - \\
\hline $\operatorname{LiMg}\left(\mathrm{BH}_{4}\right)_{3} \cdot 2 \mathrm{NH}_{3}[326]$ & - & - & - & $>95[326]$ & - \\
\hline $\mathrm{LiCa}\left(\mathrm{BH}_{4}\right)_{3} \cdot \mathbf{2} \mathrm{NH}_{3}{ }^{[326]}$ & - & - & - & - & - \\
\hline $\mathrm{LiAl}\left(\mathrm{BH}_{4}\right)_{5} \cdot 4 \mathrm{NH}_{3}[326]$ & - & - & - & $>75^{[326]}$ & - \\
\hline $\mathrm{Li}_{2} \mathrm{Al}\left(\mathrm{BH}_{4}\right)_{5} 6 \mathrm{NH}_{3}[325 \mathrm{c}, 327]$ & - & - & $15.5^{[327]}$ & $75-300{ }^{[327]}$ & - \\
\hline $\mathbf{M g}\left(\mathrm{BH}_{4}\right)_{2} \cdot \mathbf{2} \mathrm{NH}_{3}[328]$ & Konoplev and Silina ${ }^{[329]}$ & 16 & $12.1-13.1[328 \mathrm{a}]$ & $120-400$ [328a] & 94 [328a] \\
\hline $\mathrm{Ca}\left(\mathrm{BH}_{4}\right)_{2} \cdot \mathrm{NH}_{3}[325 \mathrm{~d}, 330]$ & - & 12.6 & $\begin{array}{c}\sim 4.2^{[330 \mathrm{a}]} \\
4.7[325 \mathrm{~d}]\end{array}$ & $100-350$ [325d] & - \\
\hline $\mathrm{Ca}\left(\mathrm{BH}_{4}\right)_{2} \cdot 2 \mathrm{NH}_{3}[328 \mathrm{~b}, 330]$ & Kravchenko [331] & 13.5 & $\begin{array}{c}\sim 3[325 \mathrm{~d}, 330 \mathrm{a}] \\
12.3[330 \mathrm{~b}]\end{array}$ & $\begin{array}{c}35-250[3300 \mathrm{~b}] \\
100-350[325 d]\end{array}$ & - \\
\hline $\mathrm{Ca}\left(\mathrm{BH}_{4}\right)_{2} \cdot 4 \mathrm{NH}_{3}{ }^{[330]}$ & - & 14.5 & $\sim 2$ [330a] & $20-300$ [330a] & - \\
\hline $\mathrm{Zn}\left(\mathrm{BH}_{4}\right)_{2} \cdot \mathbf{2} \mathrm{NH}_{3}[134,328 \mathrm{~b}]$ & Zirngiebl [332] & 10.8 & $8.9^{[134]}$ & $90-200[134]$ & - \\
\hline $\mathrm{Al}\left(\mathrm{BH}_{4}\right)_{3} \cdot 2 \mathrm{NH}_{3}[333]$ & - & 17 & $13.7[333]$ & $108[333]$ & - \\
\hline $\mathrm{Al}\left(\mathrm{BH}_{4}\right)_{3} \cdot 3 \mathrm{NH}_{3}{ }^{[333]}$ & - & 17.1 & $13.7^{[333]}$ & $113^{[333]}$ & - \\
\hline $\mathrm{Al}\left(\mathrm{BH}_{4}\right)_{3} \cdot 4 \mathrm{NH}_{3}{ }^{[333]}$ & - & 17.1 & $15.5^{[333]}$ & $100-250[333]$ & - \\
\hline $\mathrm{Al}\left(\mathrm{BH}_{4}\right)_{3} \cdot 5 \mathrm{NH}_{3}{ }^{[333]}$ & - & 17.2 & $16.88^{[333]}$ & $120-170[333]$ & - \\
\hline $\mathrm{Al}\left(\mathrm{BH}_{4}\right)_{3} \cdot 6 \mathrm{NH}_{3}{ }^{[334]}$ & - & 17.4 & $11.8^{[334 \mathrm{a}]}$ & $\begin{array}{c}25-300 \text { [3344] } \\
150-200 \text { [334a] }\end{array}$ & - \\
\hline $\mathrm{Ti}\left(\mathrm{BH}_{4}\right)_{3} \cdot 3 \mathrm{NH}_{3}{ }^{[335]}$ & - & 14.6 & $14[335]$ & $60-300[335]$ & - \\
\hline $\mathrm{Ti}\left(\mathrm{BH}_{4}\right)_{3} \cdot 5 \mathrm{NH}_{3}{ }^{[335]}$ & - & 15.1 & $\sim 13.4[335]$ & $50-300[335]$ & - \\
\hline $\mathrm{Li}_{2} \mathrm{Ti}\left(\mathrm{BH}_{4}\right)_{5} \cdot 3 \mathrm{NH}_{3}{ }^{[335]}$ & - & - & $15.8[335]$ & $75-300[335]$ & - \\
\hline $\left.\mathrm{LiBH}_{4} \cdot \mathrm{NH}_{3} / \mathrm{Ca}\left(\mathrm{BH}_{4}\right)_{2}\right)^{[325 \mathrm{~d}]}$ & - & - & $8-11.1^{[325 d]}$ & $100-350[325 \mathrm{~d}]$ & - \\
\hline $\mathrm{LiBH}_{4} \cdot \mathrm{NH}_{3} / \mathrm{Mg}\left(\mathrm{BH}_{4}\right)_{2}{ }^{[336]}$ & - & - & $15^{[336]}$ & $100-500[336]$ & - \\
\hline $\mathrm{Ca}\left(\mathrm{BH}_{4}\right)_{2} \cdot \mathrm{NH}_{3} / \mathrm{LiBH}_{4}{ }^{[325 \mathrm{~d}]}$ & - & - & $12.1^{[325 \mathrm{~d}]}$ & $100-350[325 d]$ & - \\
\hline $\mathrm{Ca}\left(\mathrm{BH}_{4}\right)_{2} \cdot \mathbf{2} \mathrm{NH}_{3} / \mathrm{LiBH}_{4}{ }^{[325 \mathrm{~d}]}$ & - & - & $7.7^{[325 \mathrm{~d}]}$ & $100-350$ [325d] & - \\
\hline $\mathrm{Ca}\left(\mathrm{BH}_{4}\right)_{2} \cdot \mathrm{NH}_{3} / \mathrm{Mg}\left(\mathrm{BH}_{4}\right)_{2}[330 \mathrm{a}]$ & - & - & $\sim 6.8^{[330 \mathrm{a}]}$ & $100-450$ [330a] & - \\
\hline $\left.\mathrm{Ca}\left(\mathrm{BH}_{4}\right)_{2} \cdot 2 \mathrm{NH}_{3} / \mathrm{Mg}\left(\mathrm{BH}_{4}\right)_{2}\right)^{[330 \mathrm{a}]}$ & - & - & $\sim 8.5$ [330a] & $100-500$ [330a] & - \\
\hline $\mathrm{Ca}\left(\mathrm{BH}_{4}\right)_{2} \cdot 4 \mathrm{NH}_{3} / \mathrm{Mg}\left(\mathrm{BH}_{4}\right)_{2}{ }^{[30 \mathrm{a}]}$ & - & - & $7.4-10^{[330 \mathrm{a}]}$ & $100-400$ [330a] & - \\
\hline $\mathrm{LiMg}\left(\mathrm{BH}_{4}\right)_{3}\left(\mathrm{NH}_{3}\right) / \mathrm{LiBH}_{4}{ }^{[336]}$ & - & - & $<15.7[336]$ & $100-500[336]$ & $93.5^{[336]}$ \\
\hline $\mathrm{Al}\left(\mathrm{BH}_{4}\right)_{3} \cdot 4 \mathrm{NH}_{3} / 2 \mathrm{LiBH}_{4}{ }^{[333]}$ & - & 16.5 & $14.2-16.1^{[333]}$ & $100-2500^{[333]}$ & - \\
\hline $\mathrm{Al}\left(\mathrm{BH}_{4}\right)_{3} \cdot 5 \mathrm{NH}_{3} / 2 \mathrm{LiBH}_{4}{ }^{[333]}$ & - & 16.6 & $15.4-15.8^{[333]}$ & $120-160[333]$ & - \\
\hline
\end{tabular}


Table 7. Summary of reported modifications on the thermodynamics and kinetics of borohydrides via nanoconfinement.

\begin{tabular}{|c|c|c|c|c|c|c|}
\hline & \multirow{2}{*}{ Nano scaffolds } & \multirow{2}{*}{ Particle size $(\mathrm{nm})$} & \multirow{2}{*}{ Method } & Thermodynamic modifications & Kinetics modifications & \multirow{2}{*}{ Ref. } \\
\hline & & & & Reversibility ( $T$ and $P$ ) & $T_{\text {des }}$ and Des. rate (wt.min ${ }^{-1}$ ) & \\
\hline \multirow{18}{*}{$\mathrm{LiBH}_{4}$} & \multirow{4}{*}{ Carbon aerogels } & 9 & melt-infiltration & - & $300-500^{\circ} \mathrm{C}$ & [337] \\
\hline & & 13 & melt-infiltration & $400{ }^{\circ} \mathrm{C}, 100$ bar & $381^{\circ} \mathrm{C}, 0.0083$ & [149] \\
\hline & & 15 & melt-infiltration & - & $300-500{ }^{\circ} \mathrm{C}$ & [337] \\
\hline & & 25 & melt-infiltration & $400^{\circ} \mathrm{C}, 100$ bar & $390^{\circ} \mathrm{C}$ & [149] \\
\hline & \multirow{3}{*}{ activated carbon } & 2 & melt-infiltration & $400^{\circ} \mathrm{C}, 100$ bar & $375^{\circ} \mathrm{C}$ & [149] \\
\hline & & - & ball milling & $400^{\circ} \mathrm{C}, 100 \mathrm{bar}$ & $450^{\circ} \mathrm{C}, 0.11$ & [316] \\
\hline & & $1.75-3.2$ & solvent impregnation & $300^{\circ} \mathrm{C}, 50 \mathrm{bar}$ & $360-500{ }^{\circ} \mathrm{C}, 0.038$ & [338] \\
\hline & SWNT & - & ball milling & $400^{\circ} \mathrm{C}, 100 \mathrm{bar}$ & $450^{\circ} \mathrm{C}, 0.12-0.228$ & {$[316,339]$} \\
\hline & \multirow{2}{*}{ mesoporous carbon } & 4 & solvent impregnation & - & $200-500{ }^{\circ} \mathrm{C}$ & [340] \\
\hline & & 5 & ball milling & $350^{\circ} \mathrm{C}, 30$ bar & $293-400^{\circ} \mathrm{C}, 0.006$ & [341] \\
\hline & mesoporous carbon $+\mathrm{NbF}_{5}$ & 3.8 & melt-infiltration & $200^{\circ} \mathrm{C}, 60$ bar & $150^{\circ} \mathrm{C}$ & [342] \\
\hline & \multirow{2}{*}{ nanoporous carbon } & 2 & melt-infiltration & - & $220-400^{\circ} \mathrm{C}$ & {$[337,343]$} \\
\hline & & 4 & melt-infiltration & $250^{\circ} \mathrm{C}, 60$ bar & $300-500^{\circ} \mathrm{C}$ & [337] \\
\hline & nanoporous carbon $+\mathrm{Ni}$ & $2-3$ & melt-infiltration & $320^{\circ} \mathrm{C}, 40$ bar & $200-400^{\circ} \mathrm{C}, 0.04$ & [344] \\
\hline & Cu-MOFs & $0.9 \mathrm{~nm}$ & solvent impregnation & - & $75-300^{\circ} \mathrm{C}$ & [83] \\
\hline & SBA-15 & - & melt-infiltration & - & $150-400^{\circ} \mathrm{C}$ & [345] \\
\hline & PMMA-co-BM & - & solvent impregnation & $140^{\circ} \mathrm{C}, 50 \mathrm{bar}$ & $120^{\circ} \mathrm{C}, 0.003$ & [346] \\
\hline & Cus & - & solvent impregnation & $300^{\circ} \mathrm{C}, 60 \mathrm{bar}$ & $40-200^{\circ} \mathrm{C}$ & [154] \\
\hline \multirow{2}{*}{$\mathrm{NaBH}_{4}$} & Ni core-shell & $10-200$ & solvent impregnation & $350^{\circ} \mathrm{C}, 40$ bar & $50-500{ }^{\circ} \mathrm{C}$ & [114] \\
\hline & Cus & - & solvent impregnation & $300^{\circ} \mathrm{C}, 60$ bar & $25-400^{\circ} \mathrm{C}$ & [154] \\
\hline \multirow{3}{*}{$\mathrm{Mg}\left(\mathrm{BH}_{4}\right)_{2}$} & activated carbon & $<2$ & solvent impregnation & - & $170-500^{\circ} \mathrm{C}$ & [347] \\
\hline & mesoporous carbon & 3.6 & solvent impregnation & - & $155-450^{\circ} \mathrm{C}, 0.0125$ & [348] \\
\hline & mesoporous carbon $+\mathrm{Ni}$ & 3.6 & solvent impregnation & - & $75-450^{\circ} \mathrm{C}, 0.05$ & [348] \\
\hline \multirow{2}{*}{$\mathrm{Ca}\left(\mathrm{BH}_{4}\right)_{2}$} & mesoporous carbon & $3-5$ & melt-infiltration & - & $200-600^{\circ} \mathrm{C}$ & [349] \\
\hline & mesoporous carbon $+\mathrm{TiCl}_{3}$ & $3-5$ & melt-infiltration & - & $120-600^{\circ} \mathrm{C}$ & [349] \\
\hline
\end{tabular}


Table 8. Comparison of hydrolytic performances of selected amine boranes.

\begin{tabular}{llllll}
\hline & $\mathbf{N a B H}_{\mathbf{4}}$ & $\mathbf{N H}_{\mathbf{3}} \mathbf{B H}_{\mathbf{3}}$ & $\mathbf{N H}_{\mathbf{3}} \mathbf{B}_{\mathbf{3}} \mathbf{H}_{7}$ & $\mathbf{N a B}_{3} \mathbf{H}_{\mathbf{8}}$ & $\mathbf{N H}_{\mathbf{4}} \mathbf{B}_{3} \mathbf{H}_{\mathbf{8}}$ \\
\hline Theoretical $\mathrm{H}_{2}$ content (wt \%) & 10.8 & 19.6 & 17.7 & 12.6 & 20.5 \\
Solubility in water (wt \%) & $\sim 35$ & 26 & $>33$ & 74 & $>45$ \\
$\begin{array}{l}\text { Recoverable hydrogen as determined by the } \\
\text { solubility limited of the compound (wt \%) }\end{array}$ & 7.5 & 5.1 & 9.7 & 10.5 & 10.8 \\
$\begin{array}{l}\text { Stability in aqueous solution* } \\
\text { Stable under }\end{array}$ & stable & stable & stable & stable \\
& $\begin{array}{l}\text { strong alkaline } \\
\text { conditions }\end{array}$ & & & & \\
\hline
\end{tabular}

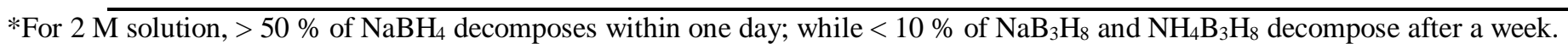


Table 9. Hydrogen properties of selected metal amidoborane. More details on the properties of metal amidoboranes and related ammoniates compounds can be found in the extensive review of Chau et al. ${ }^{[16 \mathrm{~b}]}$

\begin{tabular}{|c|c|c|c|c|c|c|c|c|}
\hline & \multirow[b]{2}{*}{ Discovery } & \multirow[b]{2}{*}{ Synthetic routes } & \multicolumn{3}{|c|}{ Hydrogen capacity } & \multirow[b]{2}{*}{$\mathrm{T}$ decomp. $\left({ }^{\circ} \mathrm{C}\right)$} & \multirow[b]{2}{*}{ Dehydrogenation path } & \multirow[b]{2}{*}{$\begin{array}{l}\text { Reversibility } \\
(\mathrm{T} \text { and } \mathrm{P})\end{array}$} \\
\hline & & & $\begin{array}{l}\text { Theoretical } \\
\text { (wt \%) }\end{array}$ & $\begin{array}{l}\text { Exp } \\
\text { (wt \%) }\end{array}$ & $\mathrm{Kg} \cdot \mathrm{m}^{-3}$ & & & \\
\hline $\mathrm{LiNH}_{2} \mathrm{BH}_{3}$ & - & $\mathrm{NH}_{3} \mathrm{BH}_{3}+\mathrm{LiH} \rightarrow \mathrm{LiNH}_{2} \mathrm{BH}_{3}+\mathrm{H}_{2}$ (ball milled [173-174]) & 18.9 & 11.0 & - & $911^{[173-174]}$ & $\mathrm{LiNH}_{2} \mathrm{BH}_{3} \rightarrow \mathrm{LiNBH}+2 \mathrm{H}_{2}$ & - \\
\hline $\mathrm{NaNH}_{2} \mathrm{BH}_{3}$ & $\begin{array}{l}\text { H. I. Schlesinger } \\
\text { \& A. B. Burg }{ }^{[171]}\end{array}$ & 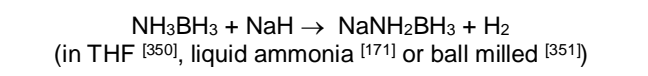 & 13.2 & 7.4 & - & $91^{[350]}$ & $\mathrm{NaNH}_{2} \mathrm{BH}_{3} \rightarrow \mathrm{NaNBH}+2 \mathrm{H}_{2}$ & - \\
\hline $\mathrm{KNH}_{2} \mathrm{BH}_{3}$ & - & $\mathrm{NH}_{3} \mathrm{BH}_{3}+\mathrm{NaH} \rightarrow \mathrm{NaNH}_{2} \mathrm{BH}_{3}+\mathrm{H}_{2}$ (in THF [352]) & 10.1 & 6.5 & - & 80 [352] & $\mathrm{KNH}_{2} \mathrm{BH}_{3} \rightarrow \mathrm{KNBH}+2 \mathrm{H}_{2}$ & - \\
\hline $\mathrm{Ca}\left(\mathrm{NH}_{2} \mathrm{BH}_{3}\right)_{2}$ & - & $\begin{aligned} 2 \mathrm{NH}_{3} \mathrm{BH}_{3} & +\mathrm{CaH}{ }_{2} \rightarrow \mathrm{Ca}(\mathrm{thf})_{2}\left(\mathrm{NH}_{2} \mathrm{BH}_{3}\right)_{2}+2 \mathrm{H}_{2} \\
& \rightarrow \mathrm{Ca}\left(\mathrm{NH}_{2} \mathrm{BH}_{3}\right)_{2}+2 \mathrm{THF}^{[353]}\end{aligned}$ & 14.0 & 8.0 & - & $\begin{array}{l}170-300[353] \\
100-150[174]\end{array}$ & $\mathrm{Ca}\left(\mathrm{NH}_{2} \mathrm{BH}_{3}\right)_{2} \rightarrow \mathrm{Ca}(\mathrm{NHBH})_{2}+4 \mathrm{H}_{2}$ & - \\
\hline $\mathrm{Mg}\left(\mathrm{NH}_{2} \mathrm{BH}_{3}\right)_{2}$ & - & $\begin{array}{c}2 \mathrm{NH}_{3} \mathrm{BH}_{3}+\mathrm{MgH} \mathrm{H}_{2} \rightarrow \mathrm{Mg}\left(\mathrm{NH}_{2} \mathrm{BH}_{3}\right)_{2}+2 \mathrm{H}_{2} \\
2 \mathrm{NH}_{3} \mathrm{BH}_{3}+\mathrm{Mg} \rightarrow \mathrm{Mg}\left(\mathrm{NH}_{2} \mathrm{BH}\right)_{2}+\mathrm{H}_{2} \text { (ball milled [354]) }\end{array}$ & 16.7 & 10.0 & - & $100-300[354]$ & $\mathrm{Mg}\left(\mathrm{NH}_{2} \mathrm{BH}_{3}\right)_{2} \rightarrow \mathrm{Mg}\left(\mathrm{NBH}_{0.8}\right)_{2}+4.2 \mathrm{H}_{2}$ & - \\
\hline $\mathrm{Sr}\left(\mathrm{NH}_{2} \mathrm{BH}_{3}\right)_{2}$ & - & $2 \mathrm{NH}_{3} \mathrm{BH}_{3}+\mathrm{SrH} \mathrm{H}_{2} \rightarrow \mathrm{Sr}\left(\mathrm{NH}_{2} \mathrm{BH}_{3}\right)_{2}+2 \mathrm{H}_{2}$ & 9.5 & 5.7 & - & 60 [355] & $\mathrm{Sr}\left(\mathrm{NH}_{2} \mathrm{BH}_{3}\right)_{2} \rightarrow \mathrm{Sr}(\mathrm{NHB})_{2}+4 \mathrm{H}_{2}$ & - \\
\hline $\mathrm{Y}\left(\mathrm{NH}_{2} \mathrm{BH}_{3}\right)_{3}$ & - & $\mathrm{YCl}_{3}+3 \mathrm{LiNH}_{2} \mathrm{BH}_{3} \rightarrow 3 \mathrm{LiCl}+\mathrm{Y}\left(\mathrm{NH}_{2} \mathrm{BH}_{3}\right)_{3}{ }^{[355]}$ & 8.4 & 4.9 & - & $50-250[355]$ & - & - \\
\hline $\mathrm{Na}_{2} \mathrm{Mg}\left(\mathrm{NH}_{2} \mathrm{BH}_{3}\right)_{2}$ & - & $2 \mathrm{NH}_{3} \mathrm{BH}_{3}+2 \mathrm{NaH}+\mathrm{MgH}_{2} \rightarrow \mathrm{Na}_{2} \mathrm{Mg}\left(\mathrm{NH}_{2} \mathrm{BH}_{3}\right)_{2}+2 \mathrm{H}_{2}[356]$ & 10.8 & 8.4 & - & $65-200[356]$ & - & - \\
\hline $\mathrm{NaMg}\left(\mathrm{NH}_{2} \mathrm{BH}_{3}\right)_{3}$ & - & $3 \mathrm{NH}_{3} \mathrm{BH}_{3}+\mathrm{NaMgH}_{3} \rightarrow \mathrm{NaMg}\left(\mathrm{NH}_{2} \mathrm{BH}_{3}\right)_{3}+3 \mathrm{H}_{2}[357]$ & 15.3 & 10.0 & - & $80[357]$ & $\mathrm{NaMg}\left(\mathrm{NH}_{2} \mathrm{BH} 3\right)_{3} \rightarrow \mathrm{NaMgN}_{3} \mathrm{~B}_{3} \mathrm{H}_{5}+5 \mathrm{H}_{2}$ & - \\
\hline $\mathrm{NaLi}\left(\mathrm{NH}_{2} \mathrm{BH}_{3}\right)_{2}$ & - & $\mathrm{LiH}+\mathrm{NaH}+2 \mathrm{NH}_{3} \mathrm{BH}_{3} \rightarrow \mathrm{NaLi}\left(\mathrm{NH}_{2} \mathrm{BH}_{3}\right)_{2}+2 \mathrm{H}_{2}[358]$ & 15.6 & 11.1 & - & $75^{[358]}$ & $\begin{array}{c}\mathrm{NaLi}\left(\mathrm{NO}_{.85} \mathrm{BH}_{4.6}\right)_{2} \rightarrow \mathrm{NaLi}\left(\mathrm{NO}_{2.7} \mathrm{BH}_{2.5}\right)_{2}+\sim 0.3 \mathrm{NH}_{3}+\sim 1.65 \mathrm{H}_{2} \\
\mathrm{NaLi}\left(\mathrm{N}_{0.7 \mathrm{BH}} \mathrm{BH}_{2.5}\right)_{2} \rightarrow \mathrm{NaLi}\left(\mathrm{N}_{0.7} \mathrm{BH}_{1.6) 2}+0.9 \mathrm{H}_{2}\right.\end{array}$ & - \\
\hline
\end{tabular}


Table 10. Summary of reported modifications of amide systems and associated hydrogen sorption properties.

\begin{tabular}{|c|c|c|c|c|c|c|c|c|}
\hline & \multirow{2}{*}{ System } & \multicolumn{3}{|c|}{ Hydrogen capacity (wt \%) } & \multirow{2}{*}{$\mathrm{T}$ decomp. $\left({ }^{\circ} \mathrm{C}\right)$} & \multirow{2}{*}{$\begin{array}{l}\text { Reversibility } \\
T \text { and } P\end{array}$} & \multirow{2}{*}{$\begin{array}{c}-\Delta \mathrm{H}_{\text {des }} \\
\left(\mathrm{kJ} . \mathrm{mol}^{-1} \mathrm{H}_{2}\right)\end{array}$} & \multirow{2}{*}{$\underset{\left(\mathrm{J} . \mathrm{mol}^{-1} . \mathrm{K}^{-1} \mathrm{H}_{2}\right)}{\Delta \mathrm{S}}$} \\
\hline & & Theoretical & Exp. & Rehydro. & & & & \\
\hline \multirow{10}{*}{$\mathrm{LiNH}_{2}{ }^{[359]}$} & $\mathrm{LiNH}_{2}+2 \mathrm{LiH} \leftrightarrow \mathrm{Li}_{3} \mathrm{~N}+2 \mathrm{H}_{2}$ & 10 & $\begin{array}{c}9.3[179] \\
9.5 / 6.5[185 a] \\
7[360] \\
5[361]\end{array}$ & $\begin{array}{l}5.2^{[360]} \\
6.8^{[362]}\end{array}$ & $\begin{array}{c}150-400[179] \\
150-320[185 a] \\
180-400[363] \\
160[360]\end{array}$ & $\begin{array}{c}230,255^{\circ} \mathrm{C}, 30 \text { bar }[179] \\
240^{\circ} \mathrm{C} \text { [360, 363] } \\
230^{\circ} \mathrm{C}, 7 \text { bar }{ }^{[362]}\end{array}$ & $\begin{array}{c}85 \sim-99[364] \\
96.3[363] \\
99[179] \\
116\end{array}$ & - \\
\hline & $\mathrm{LiNH}_{2}+\mathrm{LiH} \leftrightarrow \mathrm{Li}_{2} \mathrm{NH}+\mathrm{H}_{2}$ & 6.5 & 6 [185a] & $\begin{array}{c}6.5^{[179]} \\
6-7^{[365]} \\
\end{array}$ & $\begin{array}{c}\sim^{25[366]} \\
160[367] \\
150-400[185 a] \\
\end{array}$ & $\begin{array}{c}255^{\circ} \mathrm{C}, 30 \text { bar }{ }^{[179]} \\
300-400{ }^{\circ} \mathrm{C}, 90 \text { bar }{ }^{[365]} \\
240^{\circ} \mathrm{C}, 32 \text { bar }{ }^{[367]} \\
\end{array}$ & $\begin{array}{c}44.5^{[363]} \\
51^{[367]} \\
66.1^{[179]} \\
\end{array}$ & $-120[365]$ \\
\hline & $\mathrm{LiNH}_{2}+\mathrm{LiH} \leftrightarrow \mathrm{Li}_{2} \mathrm{NH}+\mathrm{H}_{2}$ (Ti doped) & & $5.5^{[363]}$ & - & $150-200[363]$ & $180^{\circ} \mathrm{C}, 3$ bar ${ }^{[363]}$ & - & - \\
\hline & $\mathrm{Li} 2 \mathrm{NH}+\mathrm{LiH} \leftrightarrow \mathrm{Li}_{3} \mathrm{~N}+\mathrm{H}_{2}$ & 5.5 & & $\begin{array}{l}5.2[368] \\
6^{[369]}\end{array}$ & $200-400[369]$ & $\begin{array}{c}150-500{ }^{\circ} \mathrm{C}, 1 \mathrm{bar}[369] \\
180,198^{\circ} \mathrm{C}, 4-7 \mathrm{bar}[368]\end{array}$ & $165^{[363]}$ & - \\
\hline & $2 \mathrm{LiNH}_{2}+\mathrm{LiAlH}_{4} \leftrightarrow \mathrm{Li}_{3} \mathrm{AlN}_{2}+4 \mathrm{H}_{2}$ & 9.6 & $4.1^{[313 b]}$ & - & $25-600[313 b]$ & - & - & - \\
\hline & $2 \mathrm{LiNH}_{2}+2 \mathrm{LiAlH}_{4} \leftrightarrow 2 \mathrm{Li}_{2} \mathrm{AINH}+5 \mathrm{H}_{2}$ & - & $\sim 8[370]$ & - & $50-230,350-450[370]$ & & $27[370]$ & \\
\hline & $6 \mathrm{LiNH}_{2}+2 \mathrm{Li}_{3} \mathrm{AlH} 6 \leftrightarrow 6 \mathrm{Li} \mathrm{inH}_{2}+2 \mathrm{Al}+9 \mathrm{H}_{2}$ & 7.4 & 7.1 (TiCl3-AlCl3 catalyst) ${ }^{[371]}$ & $\sim 7.1^{[371]}$ & $150-300[371]$ & $300^{\circ} \mathrm{C}, 138$ bar ${ }^{[371]}$ & - & - \\
\hline & $8 \mathrm{LiNH}_{2}+4 \mathrm{Li}_{3} \mathrm{AlH}_{6} \leftrightarrow 4 \mathrm{Li} \mathrm{i}_{2} \mathrm{NH}+6 \mathrm{LiH}+2 \mathrm{Li}_{3} \mathrm{AlN}_{2}+2 \mathrm{Al}+15 \mathrm{H}_{2}$ & 7.6 & $6.9^{[372]}$ & $\begin{array}{c}1-2[372] \\
3-4 \text { (Ni doped) } \\
{[372]} \\
\end{array}$ & $100-500[372]$ & $200-300^{\circ} \mathrm{C}, 0.04-100 \mathrm{bar}\left[{ }^{[372]}\right.$ & - & - \\
\hline & $2 \mathrm{LiNH}_{2}+\mathrm{LiBH}_{4} \leftrightarrow \mathrm{Li}_{3} \mathrm{BN} N_{2}+4 \mathrm{H}_{2}$ & 11.9 & $\begin{array}{c}>10^{[313 \mathrm{a}]} \\
7.8^{[124]} \\
7.9^{-9.5} .^{[313 b]} \\
\end{array}$ & - & $250[124,313 a]$ & - & $23^{[124]}$ & - \\
\hline & $2 \mathrm{LiNH}_{2}+\mathrm{MgH}_{2} \leftrightarrow \mathrm{Li} 2 \mathrm{Mg}(\mathrm{NH})_{2}+2 \mathrm{H}_{2}$ & 5.35 & $\begin{array}{l}4.3^{[373]} \\
4.5[367] \\
\end{array}$ & $\begin{array}{l}4.3[373] \\
4.5^{[367]} \\
\end{array}$ & $\begin{array}{l}100^{[367]} \\
200^{[373]} \\
\end{array}$ & $\begin{array}{c}180-220^{\circ} \mathrm{C}\left[{ }^{[374]}\right. \\
200^{\circ} \mathrm{C}, 30 \text { bar }{ }^{[373]} \\
\end{array}$ & $34[367]$ & - \\
\hline \multirow{9}{*}{$\mathrm{Mg}\left(\mathrm{NH}_{2}\right)_{2}$} & $\mathrm{Mg}\left(\mathrm{NH}_{2}\right)_{2}+2 \mathrm{MgH}_{2} \leftrightarrow \mathrm{Mg}_{3} \mathrm{~N}_{2}+4 \mathrm{H}_{2}$ & 7.4 & - & - & - & $130-520^{\circ} \mathrm{C}[192 \mathrm{a}]$ & - & - \\
\hline & $\mathrm{Mg}\left(\mathrm{NH}_{2}\right)_{2}+\mathrm{MgH}_{2} \leftrightarrow 2 \mathrm{MgNH}+2 \mathrm{H}_{2}$ & 4.9 & $4.8^{[375]}$ & $4.8^{[375]}$ & $65-310^{[375]}$ & $130-520^{\circ} \mathrm{C}[192 \mathrm{a}]$ & - & - \\
\hline & $\mathrm{Mg}\left(\mathrm{NH}_{2}\right)_{2}+\mathrm{nLiH} \leftrightarrow \mathrm{Li}_{2} \mathrm{Mg}(\mathrm{NH})_{2}+(\mathrm{n}-2) \mathrm{LiH}+2 \mathrm{H}_{2}{ }^{[376]}$ & 5.6 & - & $\begin{array}{c}5.4^{[376-377]} \\
4.3^{[378]} \\
\end{array}$ & $\begin{array}{c}140-280[376-377,379] \\
210-240[378] \\
\end{array}$ & $\begin{array}{l}220^{\circ} \mathrm{C}, 8 \text { bar [376] } \\
220,110 \text { bar }{ }^{3378]}\end{array}$ & $\begin{array}{c}38.9 \sim-44.1[377] \\
41.6^{[378]} \\
\end{array}$ & - \\
\hline & $\mathrm{Mg}\left(\mathrm{NH}_{2}\right)_{2}+8 / 3 \mathrm{LiH} \leftrightarrow 1 / 3 \mathrm{Mg}_{3} \mathrm{~N}_{2}+4 / 3 \mathrm{Li} \mathrm{i}_{2} \mathrm{NH}+8 / 3 \mathrm{H}_{2}$ & 6.9 & $\sim 7^{[379-380]}$ & - & $140-280[379-380]$ & $200^{\circ} \mathrm{C}, 30$ bar ${ }^{[380 a]}$ & - & - \\
\hline & $\mathrm{Mg}\left(\mathrm{NH}_{2}\right)_{2}+4 \mathrm{LiH} \leftrightarrow 1 / 3 \mathrm{Mg}_{3} \mathrm{~N}_{2}+4 / 3 \mathrm{~L}_{3} \mathrm{NH}+4 \mathrm{H}_{2}$ & 9.1 & $\begin{array}{c}6.5[192 a] \\
7[379]\end{array}$ & - & $140-520$ [192a] [379] & - & - & - \\
\hline & $\mathrm{Mg}\left(\mathrm{NH}_{2}\right)_{2}+\mathrm{NaH}$ & - & $2.2^{[381]}$ & $2.2^{[381]}$ & $120-200[381]$ & $160-200^{\circ} \mathrm{C}, 11$ bar [381] & - & - \\
\hline & $\mathrm{Mg}\left(\mathrm{NH}_{2}\right)_{2}+4 \mathrm{CaH}_{2} \leftrightarrow \mathrm{CaMg}_{2} \mathrm{~N}_{2}+\mathrm{Ca}_{2} \mathrm{NH}+\mathrm{CaNH}+7 \mathrm{H}_{2}$ & 5 & $4.9^{[382]}$ & - & $60-510[382]$ & - & $42.4^{[382]}$ & - \\
\hline & $\mathrm{Mg}\left(\mathrm{NH}_{2}\right)_{2}+\mathrm{CaH}_{2} \leftrightarrow \mathrm{MgCa}(\mathrm{NH})_{2}+2 \mathrm{H}_{2}[383]$ & 4.1 & - & - & - & - & - & - \\
\hline & $\mathrm{Mg}\left(\mathrm{NH}_{2}\right)_{2}+\mathrm{Ca}\left(\mathrm{NH}_{2}\right)_{2}+\mathrm{LiH} \leftrightarrow \mathrm{Li}_{4} \mathrm{MgCa}(\mathrm{NH})_{4}+4 \mathrm{H}_{2}$ & 5 & $2.7[384]$ & $2.7^{[384]}$ & $50-220[384]$ & $220^{\circ} \mathrm{C}, 75$ bar $[384]$ & - & - \\
\hline \multirow{5}{*}{$\mathrm{Ca}\left(\mathrm{NH}_{2}\right)_{2}$} & $\mathrm{CaNH}+\mathrm{CaH}_{2} \leftrightarrow \mathrm{Ca}_{2} \mathrm{NH}+\mathrm{H}_{2}[385]$ & 2.1 & $2.4[385]$ & $1.9[179]$ & $60-350[385]$ & $500,550^{\circ} \mathrm{C}, 30$ bar $[179]$ & $88.7[179]$ & - \\
\hline & $\mathrm{Ca}\left(\mathrm{NH}_{2}\right)_{2}+\mathrm{CaH}_{2} \leftrightarrow 2 \mathrm{CaNH}+2 \mathrm{H}_{2}\left[{ }^{[355]}\right.$ & 3.5 & $3.2^{[385]}$ & - & $60-500[385]$ & - & - & - \\
\hline & $2 \mathrm{CaNH}+\mathrm{CaH}_{2} \leftrightarrow \mathrm{Ca}_{3} \mathrm{~N}_{2}+2 \mathrm{H}_{2}$ & 2.7 & - & $2.36^{[386]}$ & $300^{[386]}$ & $500-600^{\circ} \mathrm{C}, 27$ bar $[386]$ & - & - \\
\hline & $\mathrm{Ca}\left(\mathrm{NH}_{2}\right)_{2}+2 \mathrm{LiH} \leftrightarrow \mathrm{CaNH}+\mathrm{Li}_{2} \mathrm{NH}+2 \mathrm{H}_{2}$ & 4.5 & $4.5^{[387]}$ & $2.5^{[387]}$ & $100-300[387]$ & $180-200^{\circ} \mathrm{C}, 30$ bar [387] & - & - \\
\hline & $2 \mathrm{Ca}\left(\mathrm{NH}_{2}\right)_{2}+2 \mathrm{NaH} \leftrightarrow \mathrm{Ca}-\mathrm{Na}-\mathrm{H}+2 \mathrm{NaNH}_{2}+\mathrm{H}_{2}$ & - & $1.1^{[388]}$ & $0.96^{[388]}$ & $120-2700^{[388]}$ & $200^{\circ} \mathrm{C}, 70$ bar ${ }^{[388]}$ & - & - \\
\hline
\end{tabular}


Table 11. Hydrogen storage properties of selected aluminum compounds and associated synthetic routes.

\begin{tabular}{|c|c|c|c|c|c|c|c|c|c|c|}
\hline & \multirow{2}{*}{ Discovery } & \multirow{2}{*}{ Synthetic route } & \multirow{2}{*}{ Decomposition path } & \multicolumn{2}{|c|}{ Hydrogen capacity } & \multirow{2}{*}{$\mathrm{T}$ decomp. $\left({ }^{\circ} \mathrm{C}\right)$} & \multirow{2}{*}{$\begin{array}{l}\text { Reversibility } \\
\text { T and P }\end{array}$} & \multirow{2}{*}{$\begin{array}{c}\Delta \mathrm{H}_{\mathrm{f}} \\
\left(\mathbf{k J} \mathrm{mol}^{-1}\right)\end{array}$} & \multirow{2}{*}{$\begin{array}{c}-\Delta \mathrm{H}_{\text {des }} \\
\left(\mathbf{k J} \cdot \mathrm{mol}^{-1} \mathrm{H}_{2}\right)\end{array}$} & \multirow{2}{*}{$\underset{\left(\text { J.mol-1 } \mathrm{K}^{-1} \mathrm{H}_{2}\right)}{\Delta S}$} \\
\hline & & & & wt \% & $\mathrm{Kg} \cdot \mathrm{m}^{-3}$ & & & & & \\
\hline$\alpha-\mathrm{AlH}_{3}$ & \multirow[t]{3}{*}{$\begin{array}{l}\text { Finholt et } \\
\text { al. }{ }^{[389]}\end{array}$} & \multirow{3}{*}{$\begin{array}{c}3 \mathrm{LiAlH}_{4}+\mathrm{AlCl}_{3} \rightarrow \underset{[389-390]}{4} \mathrm{AlH}_{3}+3 \mathrm{LiCl} \text { (diethyl ether) } \\
\mathrm{AlH}_{4}^{-} \rightarrow \mathrm{AlH}_{3} \cdot \mathrm{nTHF}+1 / 2 \mathrm{H}_{2}+\mathrm{e}^{-} \\
3 \mathrm{AlH}_{4}+\mathrm{Al} \rightarrow 4 \mathrm{AlH}_{3} \cdot \mathrm{nTHF}+3 \mathrm{e}^{-[391]}\end{array}$} & $\alpha-\mathrm{AlH}_{3} \rightarrow \mathrm{Al}+3 / 2 \mathrm{H}_{2}$ & \multirow[t]{3}{*}{10.1} & \multirow[t]{3}{*}{149} & $\begin{array}{c}60-140[390 \mathrm{~b}, 392] \\
100-250[393] \\
150^{[394]}\end{array}$ & & $-129[395]$ & $\begin{array}{c}6 \sim 7.6^{[396]} \\
9.9^{[397]} \\
6.95^{[398]} \\
11.4^{[395]} \\
12.35^{[399]} \\
\end{array}$ & \multirow[t]{3}{*}{$\begin{array}{c}129[395] \\
130.7[397]\end{array}$} \\
\hline$\beta-\mathrm{AlH}_{3}$ & & & $\beta-\mathrm{AlH}_{3} \rightarrow \alpha-\mathrm{AlH}_{3} \rightarrow \mathrm{Al}+3 / 2 \mathrm{H}_{2}$ & & & $60-140[390 \mathrm{~b}, 392]$ & & & $8^{[397]}$ & \\
\hline$\gamma-\mathrm{AlH}_{3}$ & & & $\mathrm{p}-\mathrm{AlH}_{3} \rightarrow \alpha-\mathrm{AlH}_{3} \rightarrow \mathrm{Al}+3 / 2 \mathrm{H}_{2}$ & & & $60-140$ [390b, 392] & & & $7.1^{[397]}$ & \\
\hline \multirow{3}{*}{$\mathrm{NaAlH}_{4}$} & \multirow{3}{*}{$\begin{array}{l}\text { Finholt et } \\
\text { al. }{ }^{400]}\end{array}$} & \multirow{3}{*}{ 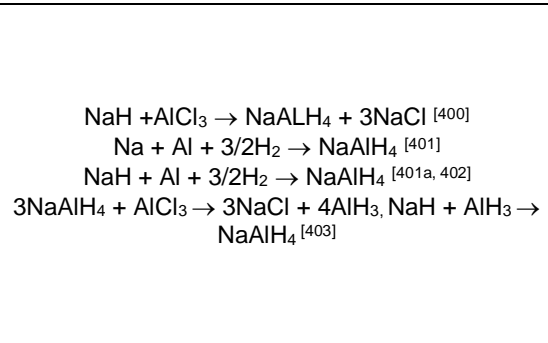 } & $\mathrm{NaAlH}_{4} \rightarrow 1 / 3 \alpha-\mathrm{Na}_{3} \mathrm{AlH} \mathrm{H}_{6}+2 / 3 \mathrm{Al}+\mathrm{H}_{2}$ & \multirow{3}{*}{7.4} & \multirow{3}{*}{ - } & $\begin{array}{c}185,230[404] \\
207[405] \\
210-220[406]] \\
90-150^{\circ} \mathrm{C} \text { (Tid doped) [403, } \\
407] \\
\end{array}$ & \multirow{3}{*}{$\begin{array}{c}150^{\circ} \mathrm{C}, 136 \mathrm{bar} \\
{[401]} \\
250^{\circ} \mathrm{C}, 175 \mathrm{bar} \\
{[404,408]} \\
150^{\circ} \mathrm{C}, 114 \mathrm{bar}(\mathrm{Ti} \\
\text { doped) }{ }^{4009]}\end{array}$} & \multirow[t]{3}{*}{$\begin{array}{c}-113 \\
-155^{[410]} \\
-18.8^{[411]}\end{array}$} & $\begin{array}{c}36[406,412] \\
37 \text { (Ti doped) }{ }_{4093}^{[403,407}\end{array}$ & \multirow{3}{*}{-} \\
\hline & & & $1 / 3 \beta-\mathrm{Na}_{3} \mathrm{AlH}_{6} \rightarrow \mathrm{NaH}+1 / 3 \mathrm{Al}+1 / 2 \mathrm{H}_{2}$ & & & $\begin{array}{c}160 \text { (Ti doped) }{ }^{[409]} \\
222[405] \\
250 \text { [406] } \\
120-180 \text { (Ti doped) }{ }^{[403]} \\
\end{array}$ & & & $\begin{array}{l}46.8[405-406,412-413] \\
\quad 47 \text { (Ti doped) }\end{array}$ & \\
\hline & & & $\mathrm{NaH} \rightarrow \mathrm{Na}+1 / 2 \mathrm{H}_{2}$ & & & $>400$ & & & $\begin{array}{c}56.5[405-406,408,412-413] \\
56.5 \text { (Ti doped) }{ }_{407}^{[403,} \\
\end{array}$ & \\
\hline \multirow{3}{*}{$\mathrm{LiAlH}_{4}$} & \multirow{3}{*}{$\begin{array}{l}\text { Finholt et } \\
\text { al. [389] }\end{array}$} & \multirow{3}{*}{ 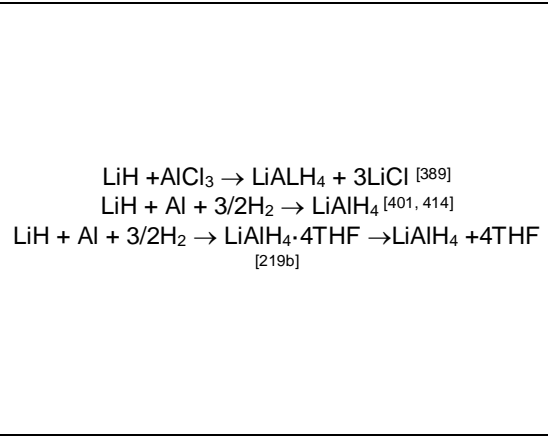 } & $\mathrm{LiAlH}_{4} \rightarrow 1 / 3 \mathrm{Li}_{3} \mathrm{AlH}_{6}+2 / 3 \mathrm{Al}+\mathrm{H}_{2}$ & \multirow{3}{*}{10.5} & \multirow{3}{*}{ - } & $\begin{array}{c}130[415] \\
150[416] \\
148-155^{[417]} \\
187-218[418] \\
201^{[419]} \\
25 \text { (Ti doped) }\left[{ }^{[420]}\right. \\
\end{array}$ & \multirow{3}{*}{$>25^{\circ} \mathrm{C}, 10^{3}$ bar ${ }^{[421]}$} & \multirow[t]{3}{*}{-119} & $\begin{array}{l}5.8^{[419]} \\
9.1^{[-148-419]} \\
10^{[219 b, 418]}\end{array}$ & \multirow{3}{*}{ - } \\
\hline & & & $1 / 3 \mathrm{Li}_{3} \mathrm{AlH}_{6} \rightarrow \mathrm{LiH}+1 / 3 \mathrm{Al}+1 / 2 \mathrm{H}_{2}$ & & & $\begin{array}{c}165-220[417] \\
180^{\circ} \mathrm{C}[416] \\
228-282[418] \\
100-175(\text { Ti doped })^{[422]} \\
\end{array}$ & & & $\begin{array}{c}310.99^{[423]} \\
25 \sim 27^{[418-419]}\end{array}$ & \\
\hline & & & $\begin{array}{l}\mathrm{LiH}+\mathrm{Al} \rightarrow \mathrm{LiAl}+1 / 2 \mathrm{H}_{2} \quad[424] \\
\quad \mathrm{LiH} \rightarrow \mathrm{Li}+1 / 2 \mathrm{H}_{2}[415,425]\end{array}$ & & & $370-483^{[418]}$ & & & $\begin{array}{c}-140 \text { [418] } \\
100.8 \text { (overall) }{ }^{[426]} \\
113.42 \text { (overall) }[423] \\
155 \text { (overall) }{ }^{[48]} \\
\end{array}$ & \\
\hline \multirow{3}{*}{$\mathrm{KAlH}_{4}$} & \multirow{3}{*}{$\begin{array}{l}\text { Ashby et al. } \\
\text { [401a] }\end{array}$} & \multirow{3}{*}{$\mathrm{KH}+\mathrm{Al}+3 / 2 \mathrm{H}_{2} \rightarrow \mathrm{KAlH}_{4}{ }^{[408]}$} & $\mathrm{KAlH}_{4} \rightarrow 1 / 3 \mathrm{~K}_{3} \mathrm{AlH}_{6}+2 / 3 \mathrm{Al}+\mathrm{H}_{2}$ & \multirow{3}{*}{5.7} & & $\begin{array}{c}290[410] \\
290,350[427] \\
300[428] \\
\end{array}$ & & $\begin{array}{l}-183.7[410] \\
-70^{[428]}\end{array}$ & $55^{[428]}$ & \\
\hline & & & $1 / 3 \mathrm{~K}_{3} \mathrm{AlH}_{6} \rightarrow \mathrm{KH}+1 / 3 \mathrm{Al}+1 / 2 \mathrm{H}_{2}$ & & 53.2 & $340[428]$ & bar $[410]$ & & $70^{[428]}$ & - \\
\hline & & & $\mathrm{KH} \rightarrow \mathrm{K}+1 / 2 \mathrm{H}_{2}$ & & & $430^{[428]}$ & & - & - & \\
\hline $\mathrm{Mg}\left(\mathrm{AlH}_{4}\right)_{2}$ & $\begin{array}{l}\text { Wiberg and } \\
\text { Baucer } \\
{[429]}\end{array}$ & $\begin{array}{c}2 \mathrm{NaAlH}_{4}+\mathrm{MgCl}_{2} \rightarrow \mathrm{Mg}\left(\mathrm{AlH}_{4}\right)_{2} \cdot 4 \mathrm{THF}+2 \mathrm{NaCl} \\
2 \mathrm{LiAlH}_{4}+\mathrm{MgCl}_{2} \rightarrow \mathrm{Mg}(\mathrm{AlH})_{2} \cdot E \mathrm{Et} 2 \mathrm{O}+2 \mathrm{NaCl}[430] \\
2 \mathrm{MgH}_{2}+\mathrm{AlCl}_{3} \rightarrow 1 / 2 \mathrm{Mg}\left(\mathrm{AlH}_{4}\right)_{2}+3 / 2 \mathrm{MgCl}_{2}[431]\end{array}$ & $\mathrm{Mg}\left(\mathrm{AlH}_{4}\right)_{2} \rightarrow \mathrm{MgH}_{2}+2 \mathrm{Al}+3 \mathrm{H}_{2}$ & 9.3 & 72.3 & $\begin{array}{c}110-130[417] \\
110-200[432] \\
150[431] \\
175[430] \\
115-150[433] \\
\end{array}$ & - & - & $\begin{array}{c}1.8^{[431]} \\
20.4^{[433]} \\
41^{[434]}\end{array}$ & - \\
\hline & & & $\begin{array}{c}\mathrm{MgH}_{2}+2 \mathrm{Al} \rightarrow 1 / 2 \mathrm{Al}_{3} \mathrm{Mg}_{2}+1 / 2 \mathrm{Al}+\mathrm{H}_{2} \\
\mathrm{MgH}_{2} \rightarrow \mathrm{Mg}^{2} \mathrm{H}_{2}\end{array}$ & & & $240-290[433]$ & & - & $76^{[434]}$ & \\
\hline & Schwab & & $\mathrm{Ca}\left(\mathrm{AlH}_{4}\right)_{2} \rightarrow \mathrm{CaAlH}_{5}+\mathrm{Al}+3 / 2 \mathrm{H}_{2}$ & & & $\begin{array}{c}80-100[417] \\
100,180[431] \\
127^{[431]} \\
\end{array}$ & & -214 & $\begin{array}{l}7^{[431]} \\
9^{[436]} \\
\end{array}$ & - \\
\hline $\mathrm{Ca}\left(\mathrm{AlH}_{4}\right)_{2}$ & $\begin{array}{l}\text { and Winters } \\
\text {-berger } \\
\text { [435] }\end{array}$ & 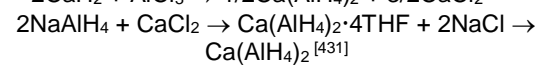 & $\mathrm{CaAlH}_{5} \rightarrow \mathrm{CaH}_{2}+\mathrm{Al}+3 / 2 \mathrm{H}_{2}$ & 7.8 & 70.4 & $250^{[431]}$ & - & & $\begin{array}{l}26^{4436]} \\
28^{4437]} \\
32^{[431]} \\
\end{array}$ & \\
\hline & & & $\mathrm{CaH}_{2} \rightarrow \mathrm{Ca}+\mathrm{H}_{2}$ & & & - & & & $172^{[436]}$ & \\
\hline
\end{tabular}


Table 12. Summary of reported modifications of alanates via nanoconfinement and "catalyst" doping.

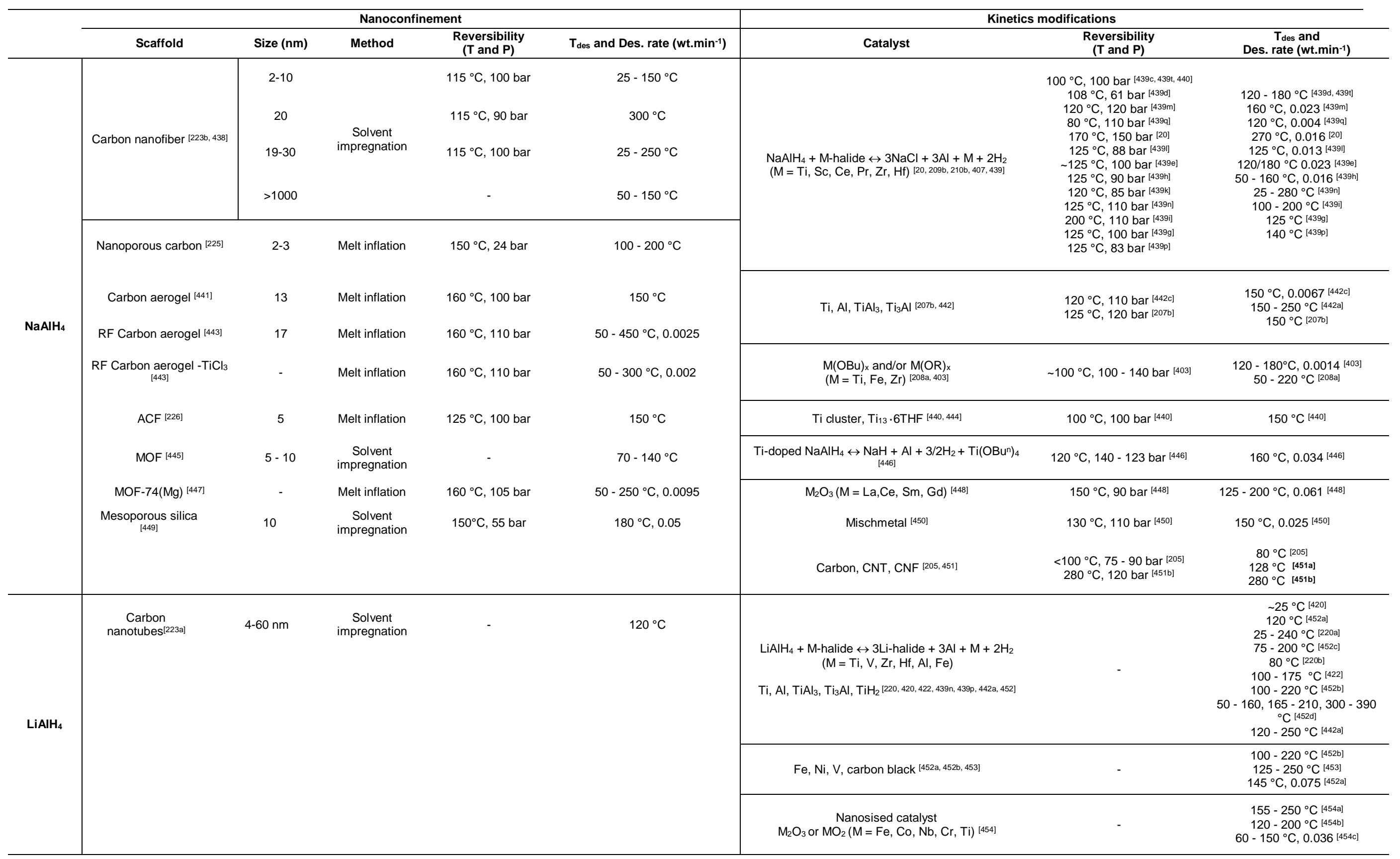


Table 13. Overview of properties of various high temperature metal hydrides. The thermal energy content ( $\left.\mathrm{kJ}^{\mathrm{kg}} \mathrm{kg}^{-1}\right)$ and hydrogen capacity (wt $\%$ ), of a high-temperature hydride determine the amount of high-temperature hydride required for a given CSP configuration, while the enthalpy of hydrogen absorption/desorption $\left(\mathrm{kJ} \cdot \mathrm{mol}^{-1} \mathrm{H}_{2}\right)$ determines how much hydrogen is required to generate a specific amount of thermal energy. This will also determine the amount of low-temperature hydride required to store the hydrogen. Potential low temperature hydrides have been summarized elsewhere. ${ }^{[236]}$

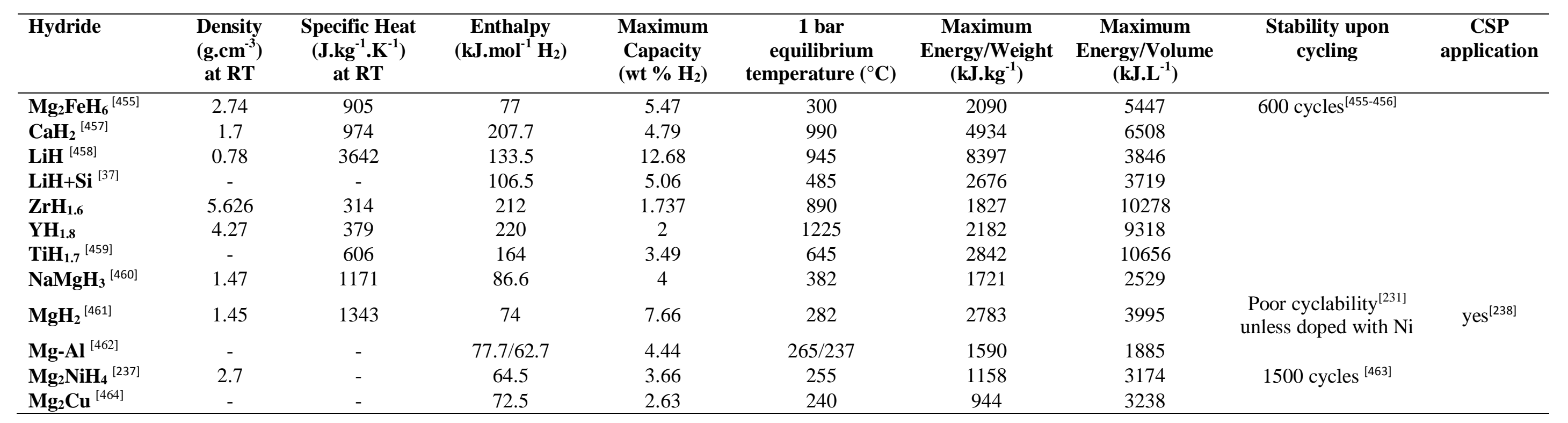




\section{Figure list}

Figure 1. Timeline reflecting the development of high capacity hydrogen storage materials and associated strategies to meet practical targets. Investigations into high capacity inorganic compounds only took-off 20 years ago following the breakthrough in reversibility with Tidoped $\mathrm{NaAlH}_{4}$.

Figure 2. a) Map of potential hydrogen materials versus the US DoE targets for hydrogen systems, liquid and compressed hydrogen tanks and current Li-ion batteries - the theoretical hydrogen capacity and decomposition temperature of the hydride is indicated; and b) achievements of selected materials (developed in the last 20 years) versus US DoE targets for hydrogen systems - the storage capacity of the materials correspond to measured values at the decomposition temperature. Compressed and liquid hydrogen do not meet the targets. Equivalent energy density is shown for Li-ion batteries.

Figure 3. Schematic illustration of a) physisorbed, b) chemisorbed and c) weakly bonded hydrogen, and d) postulated energy barriers for the hydrogenation of metal and complex hydrides. $E_{\text {phys }(H)}$ : energy for hydrogen physisorption, $E_{\text {chem }(H)}$ : energy for hydrogen chemisorption, $\mathrm{E}_{\mathrm{pen}(\mathrm{H})}$ : energy for hydrogen penetration in the subsurface, $\mathrm{E}_{\mathrm{diff}(\mathrm{H})}$ : energy for

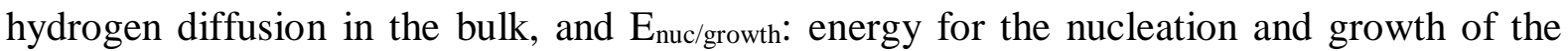
hydride phase. In complex hydrides additional barriers due to intrinsic mass transport need also to be overcome.

Figure 4. (a) Pressure Composition Isotherm (PCI) plot of hydrogen-metal systems, (b) Van't Hoff plot related to the (de)hydrogenation reaction, and (c) illustration of the decomposition 
of complex hydrides. The slope of the Van't Hoff plot is related to the enthalpy of the reaction and the intercept with the ordinate corresponds to the entropy of the reaction according to the Van't Hoff relation: $\ln \frac{p_{e q}}{p_{H_{2}}}=\frac{\Delta H^{0}}{R T}-\frac{\Delta S^{0}}{R}$.

Figure 5. Schematic illustration of a) the destabilisation and stabilisation approach and, b) Activation Energy barriers for hydrogen absorption $\left(\mathrm{E}_{\mathrm{A}}^{\mathrm{abs}}\right)$ and desorption $\left(\mathrm{E}_{\mathrm{A}}^{\mathrm{des}}\right)$. The heat released by the reaction is directly related to the internal energy $\Delta \mathrm{E}$. Destabilisation will accelerate desorption kinetics and reduce the amount of heat released. The ideal catalyst should help both the dehydrogenation and hydrogenation reaction.

Figure 6. US DoE assessment of progress for physisorbents in meeting vehicular hydrogen storage targets. $^{[465]}$

Figure 7. Examples of strategies to enhance the gravimetric hydrogen storage capacity of MOFs.

Figure 8. Examples of strategies employed to maximize the volumetric hydrogen storage capacity of MOFs.

Figure 9. a) Thermal decomposition of $\mathrm{LiBH}_{4}$ as followed by TGA/DCS/MS, and b) associated proposed reaction paths adapted from reference ${ }^{[95 b]}$ and images reflecting phase transformations of $\mathrm{LiBH}_{4}$ during its thermal decomposition.

Figure 10. Synthesis of $\mathrm{NaBH}_{4}$ from $\mathrm{NaH}$ and $\mathrm{B}$ under 173 bar hydrogen pressure at $400{ }^{\circ} \mathrm{C}$ (bleu), $500{ }^{\circ} \mathrm{C}$ (red) and $600{ }^{\circ} \mathrm{C}$ (black). a) Evolution the hydrogen pressure during the synthesis, b) XRD patterns of the material obtained after $24 \mathrm{~h}$ proving the formation of 
$\mathrm{NaBH}_{4}$ and c) Solid state ${ }^{11} \mathrm{~B}$ NMR spectrum proving the synthesis of $\mathrm{NaBH}_{4}$ at $600{ }^{\circ} \mathrm{C}(\mathrm{M}$. Christian and K.F. Aguey-Zinsou, unpublished data).

Figure 11. Decomposition temperature $\left(T_{d}\right)$ for metal borohydrides and the main alanates versus a) the Pauling electronegativity $\left(\chi_{p}\right)$ of the metal cation, and b) the enthalpy of hydrogen desorption $\left(\Delta H_{d e s}\right)$. Adapted from reference ${ }^{[130]}$ and extended to transition metals (bleu) and a few alanates (red).

Figure 12. Effect of titanium additives on the decomposition of $\mathrm{NaBH}_{4}{ }^{[136]}$

Figure 13. a) TEM image of as-synthesized $\mathrm{LiBH}_{4}$ hosted within $\mathrm{CNT}$, b) associated hydrogen cycling at $300{ }^{\circ} \mathrm{C}$ showing a rapid decrease in storage capacity, c) TEM image of the cycled material showing the expulsion of $\mathrm{LiBH}_{4}$ outside the $\mathrm{CNT},{ }^{[154]} \mathrm{e}$ ) illustration of the core-shell approach and associated TEM image of the as-synthesized $\mathrm{NaBH}_{4} @ \mathrm{Ni}$ core-shell structure, and e) associated hydrogen cycling of $\mathrm{NaBH}_{4} @ \mathrm{Ni}$ leading to stable cycling and high storage capacity. ${ }^{[114,157]}$

Figure 14: Schematic of an energy storage system for CSP. During day cycle (a) $\mathrm{T}_{\text {high }}$ and $\mathrm{T}_{\text {low }}$ are maintained to ensure constant hydrogen pressure release from $\mathrm{MH}_{-} \mathrm{T}_{\text {high }}$ and absorption by M'H_ $\mathrm{T}_{\text {low. }}$ During the nigh cycle (b) the process is reversed by either dropping or raising the temperature of $\mathrm{MH}_{-} \mathrm{T}_{\text {high }}$ or $\mathrm{M}^{\prime} \mathrm{H}_{-} \mathrm{T}_{\text {low }}$, respectively. 


\section{Figure 1}

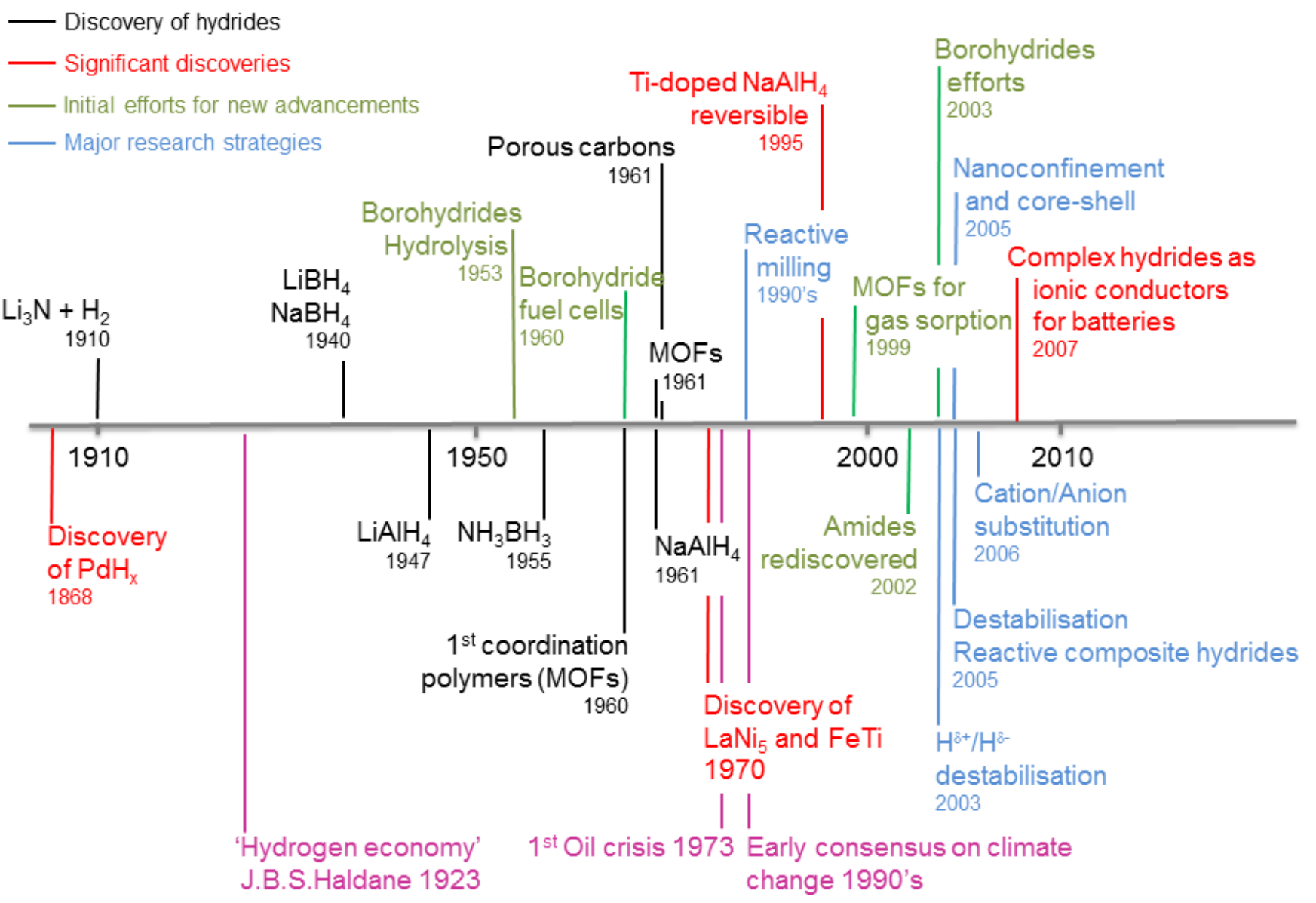




\section{Figure 2}

a) Potential high capacity hydrides

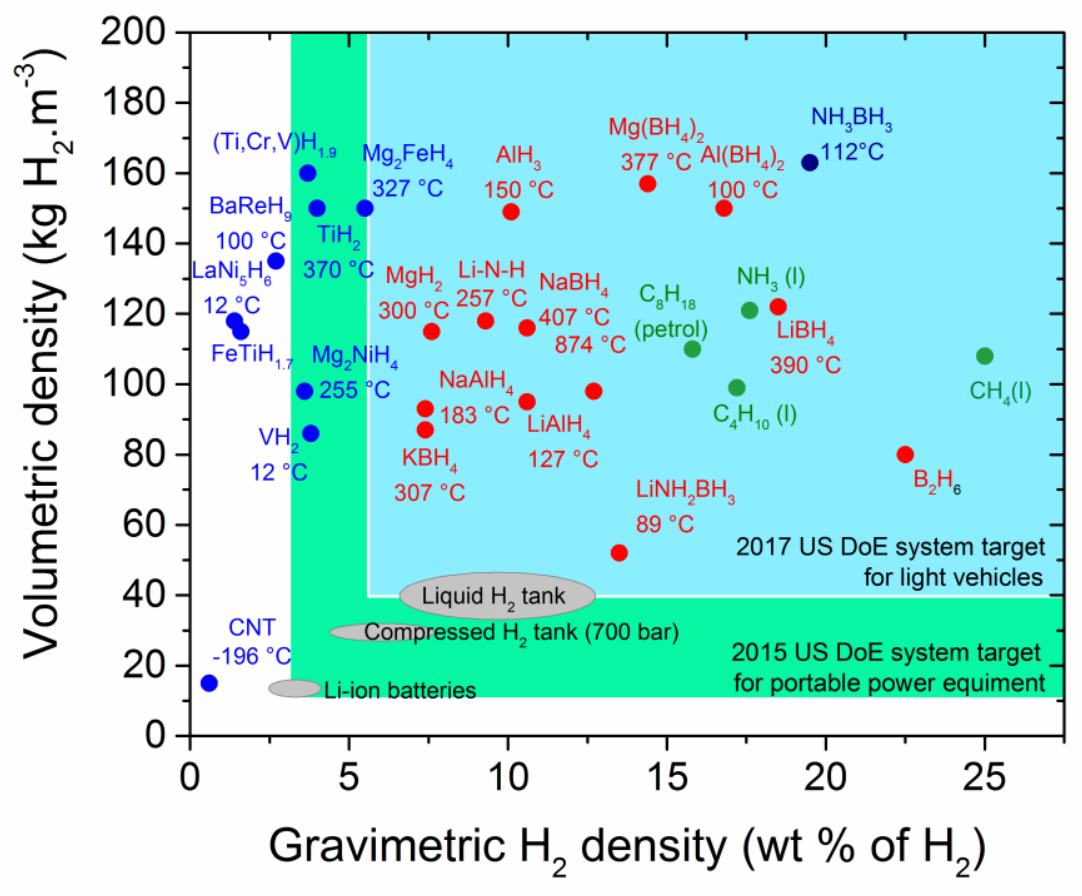

b) Examples of current achievements

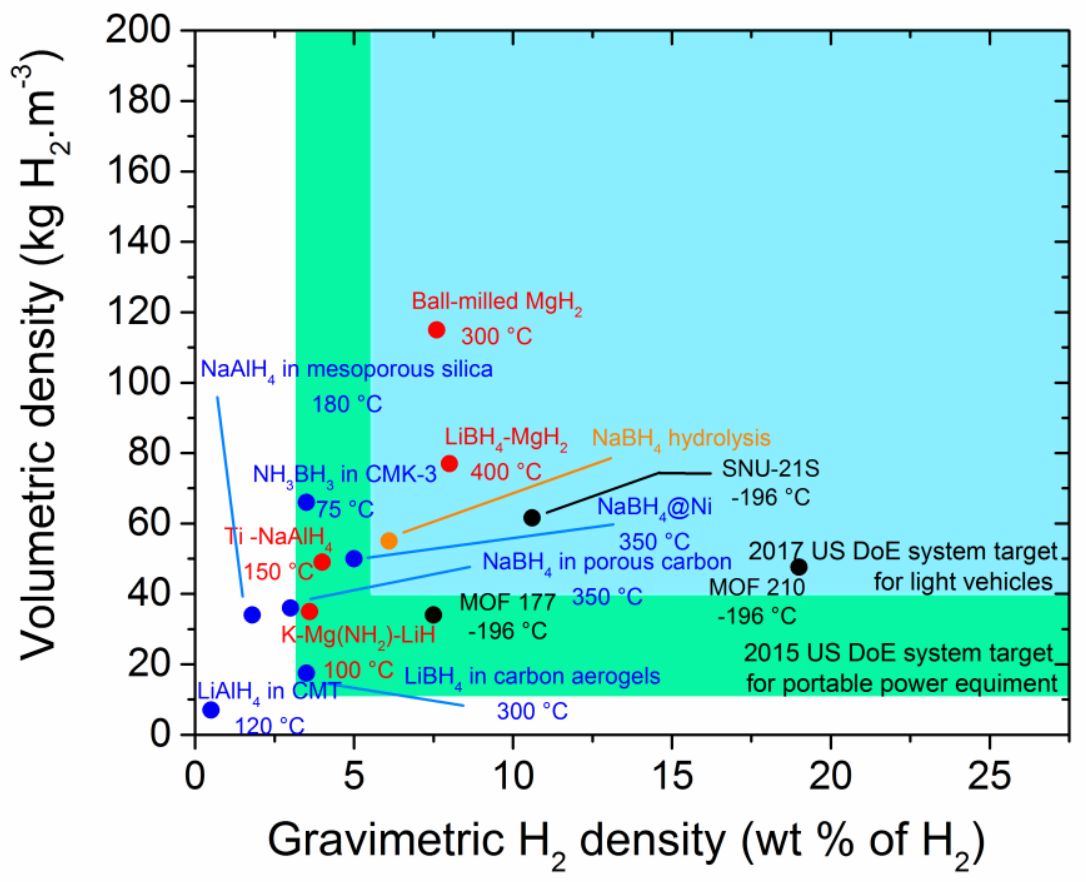




\section{Figure 3}

(a)

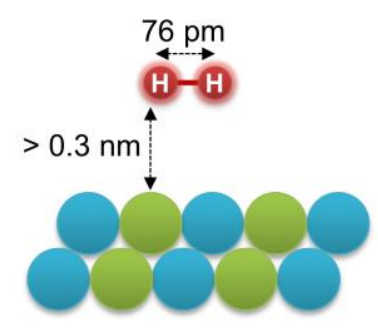

(b)

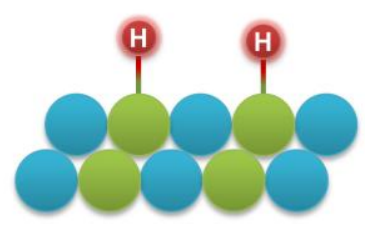

(c)

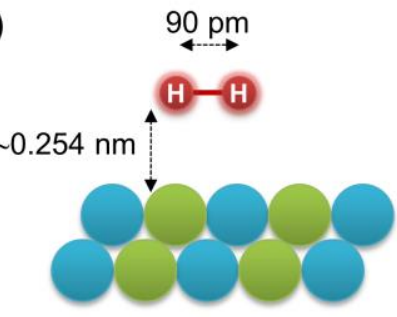

(d)

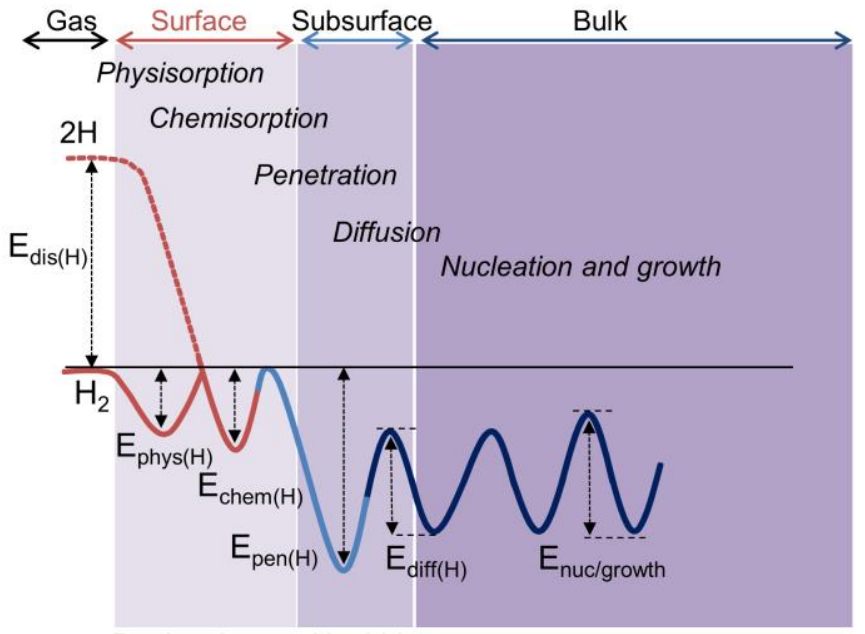

Barriers in metal hydrides

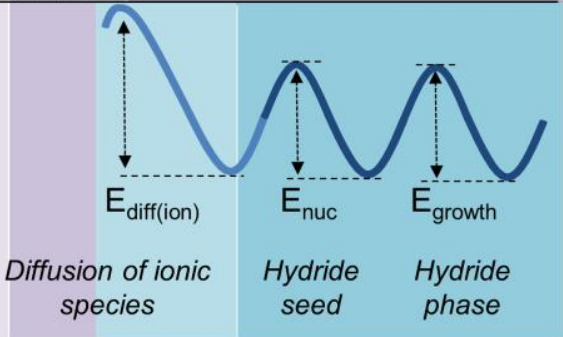

Additional barriers in complex hydrides 
Figure 4
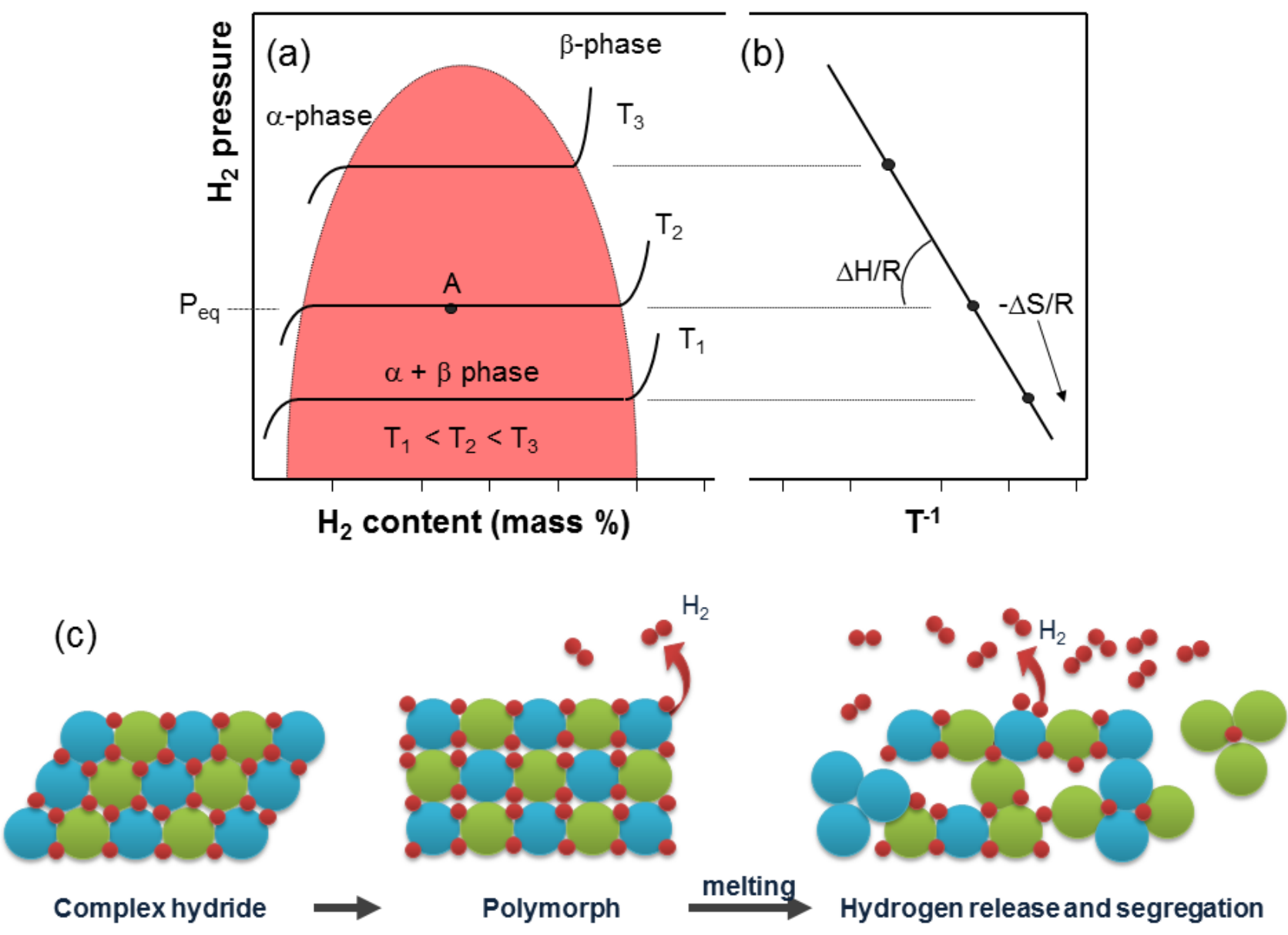
Figure 5

(a)

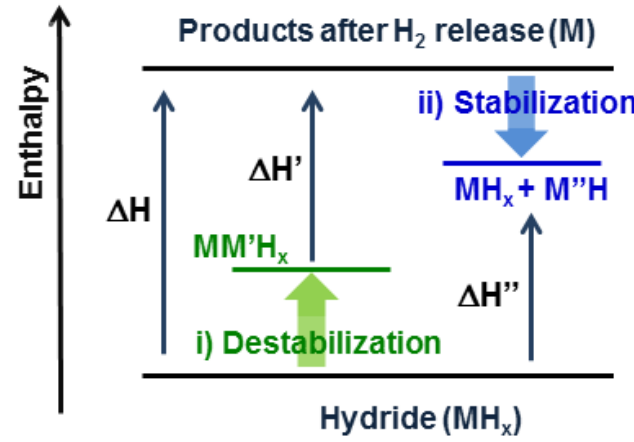

(b)

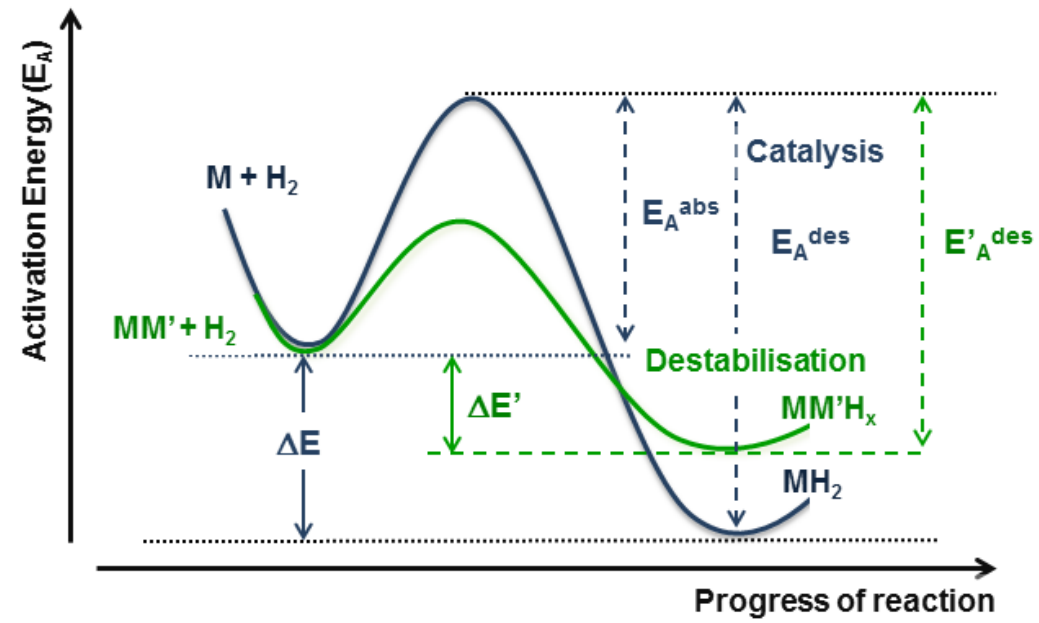




\section{Figure 6}

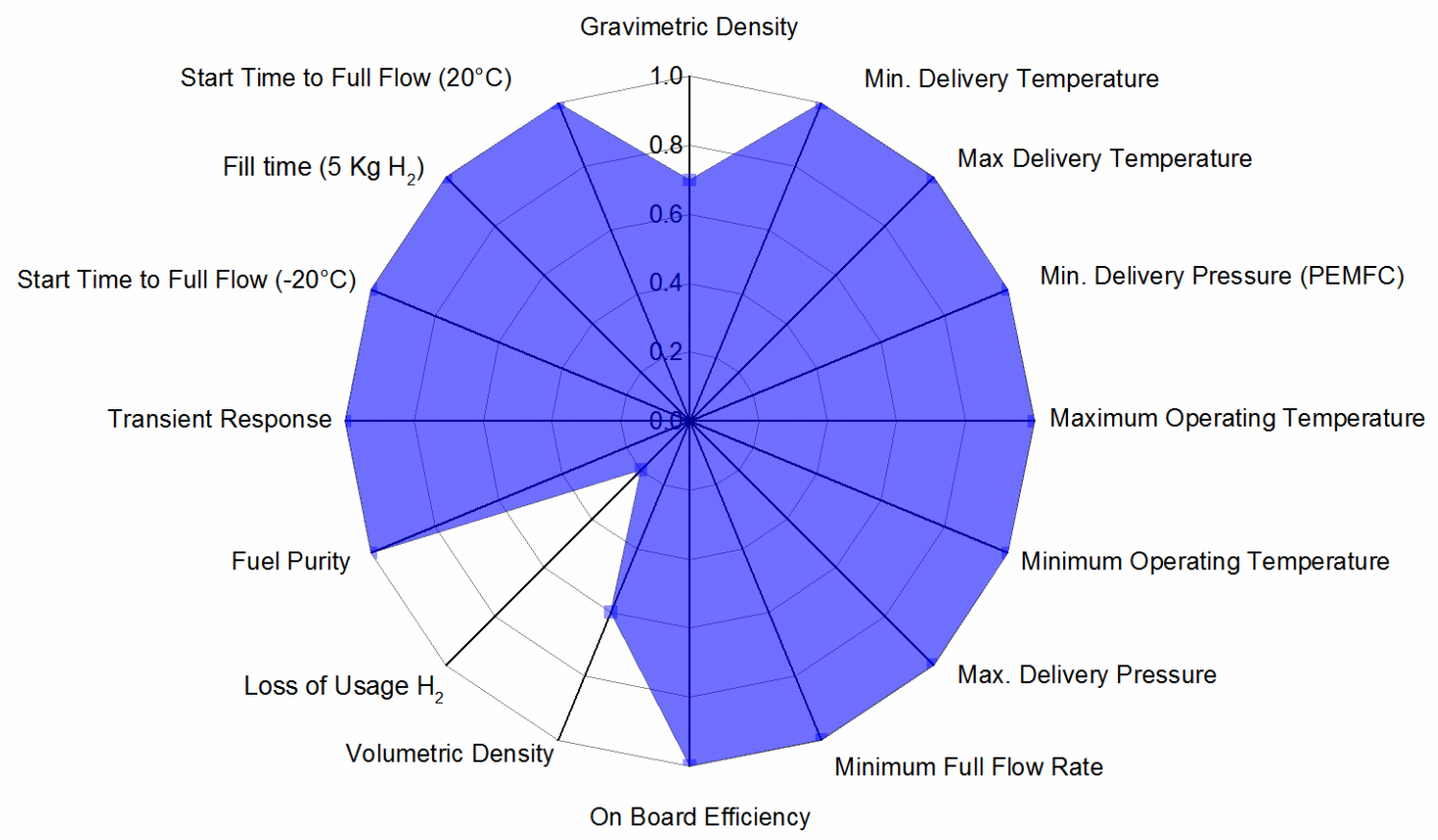




\section{Figure 7}

Positioning Adsorption Sites

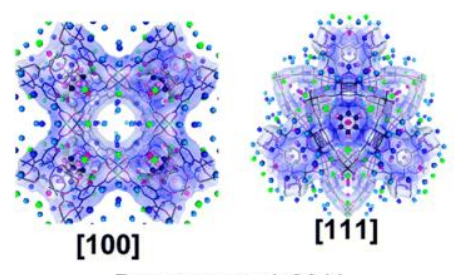

Peterson et al. 2011

Tuning Pore Size

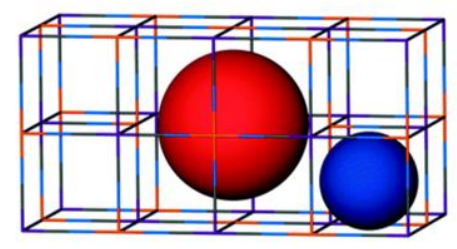

Chapman et al. 2005
Doping Framework

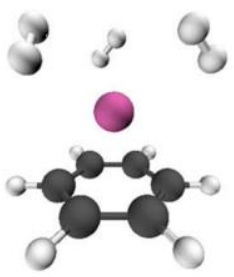

Kolmann et al. 2008
Light metal-exchange

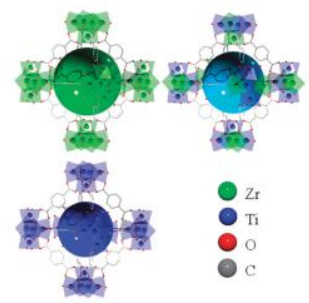

Lau et al. 2013
Exchanging High Surface Area Units

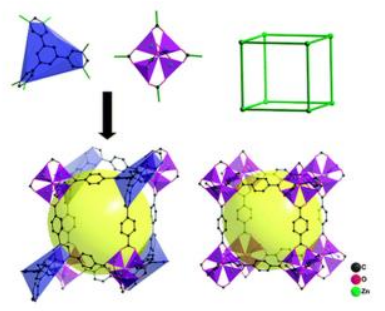

Jia et al. 2011

\section{Utilizing Pore Geometry}

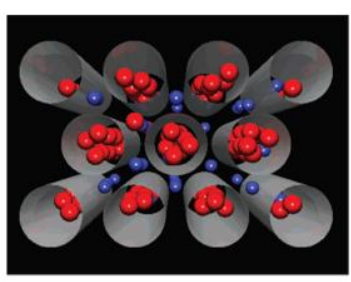

Kowalczyk et al. 2007 


\section{Figure 8}

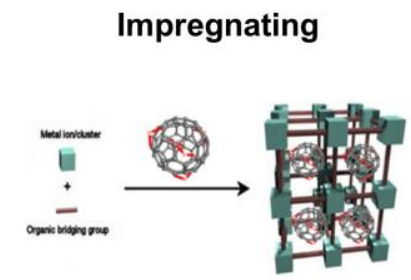

Thornton et al. 2009

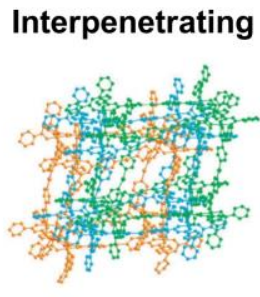

Burrows et al. 2012

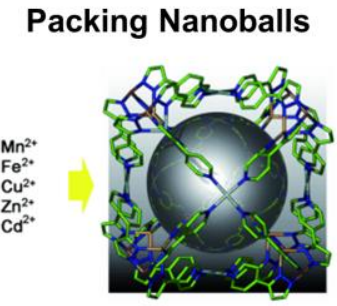

Duriska et al. 2009
Functionalizing Ligands

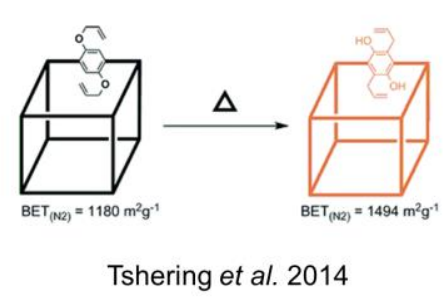

Programming Pore Size

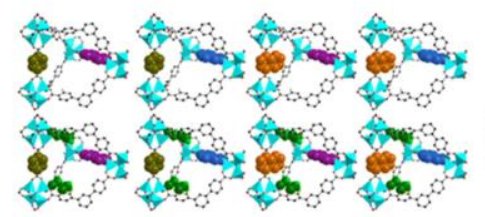

Liu et al. 2013

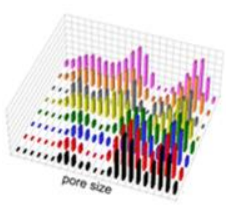

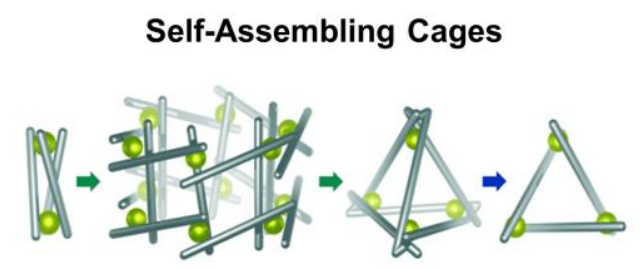

Clegg et al. 2013 


\section{Figure 9}

(a)
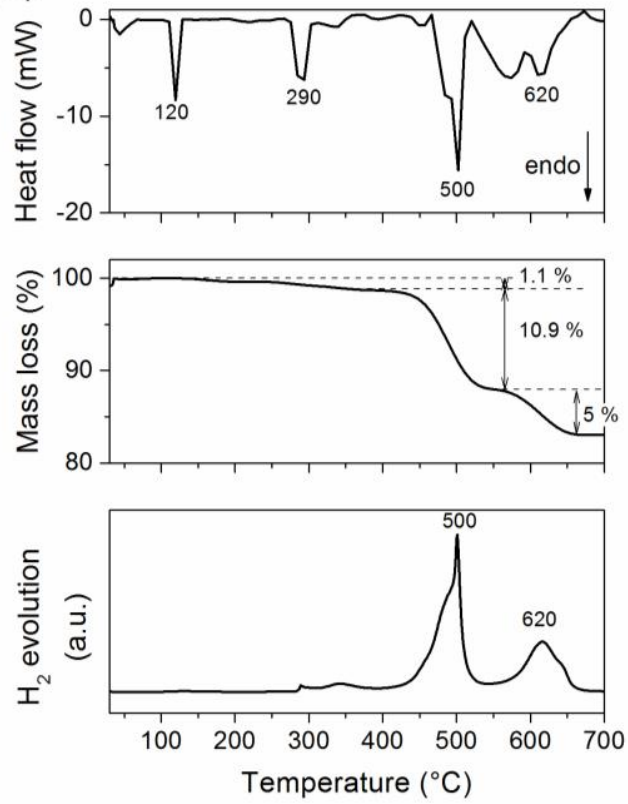

(b)

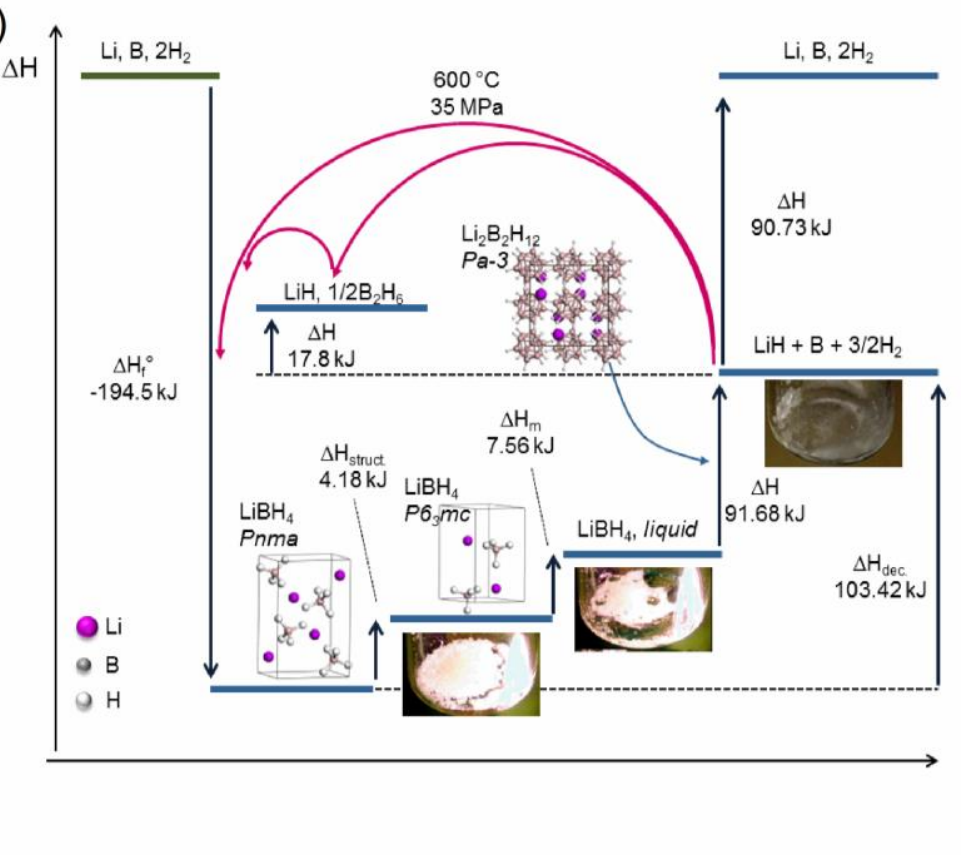


Figure 10

(a)

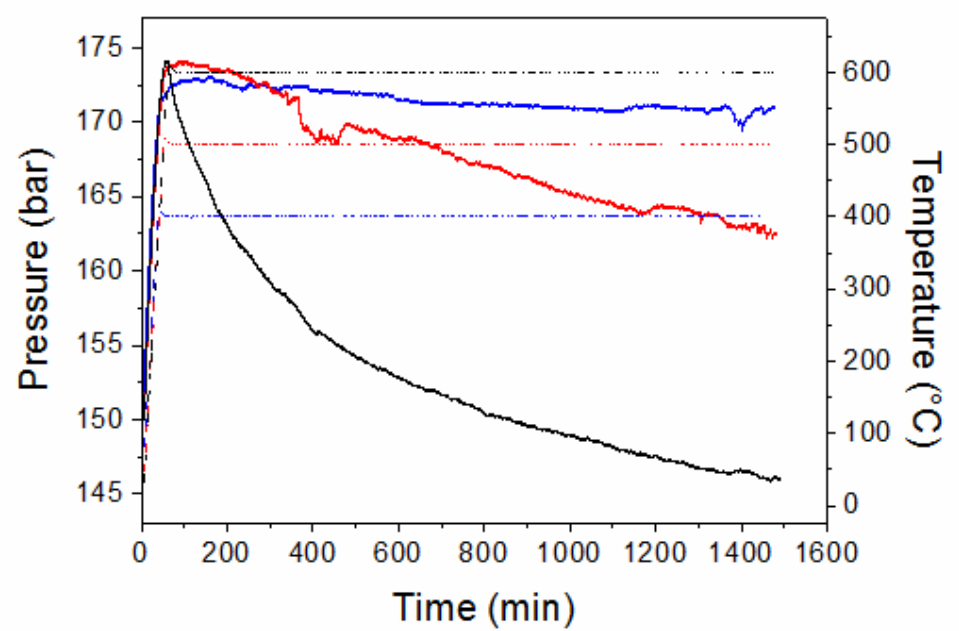

(b)

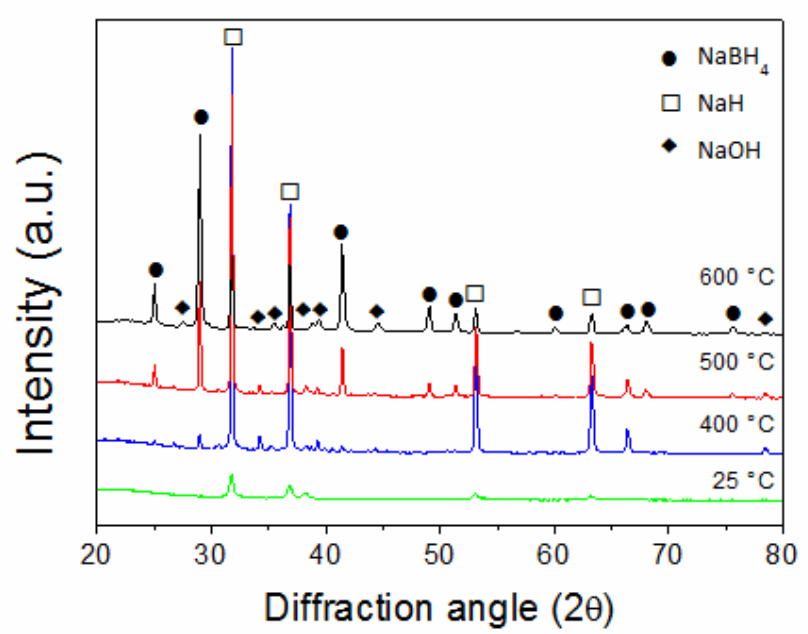

(c)

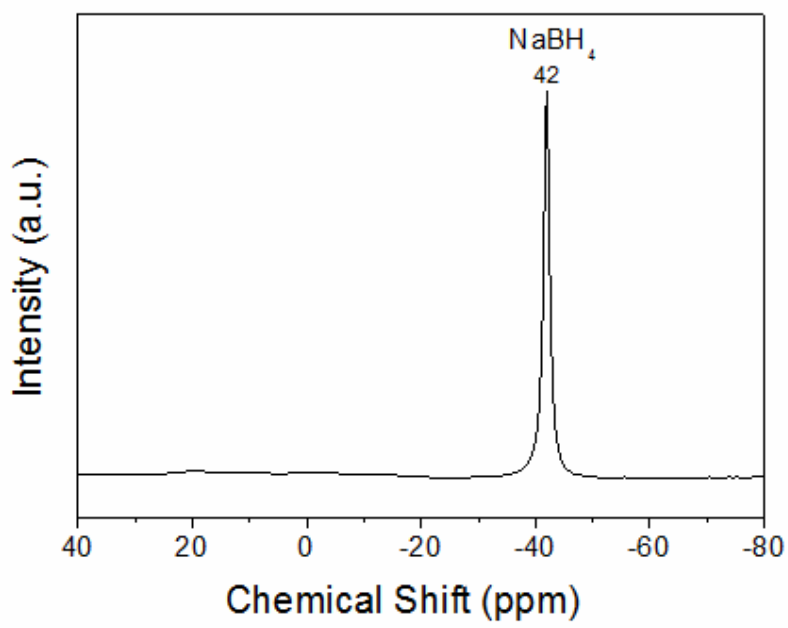


Figure 11

a)

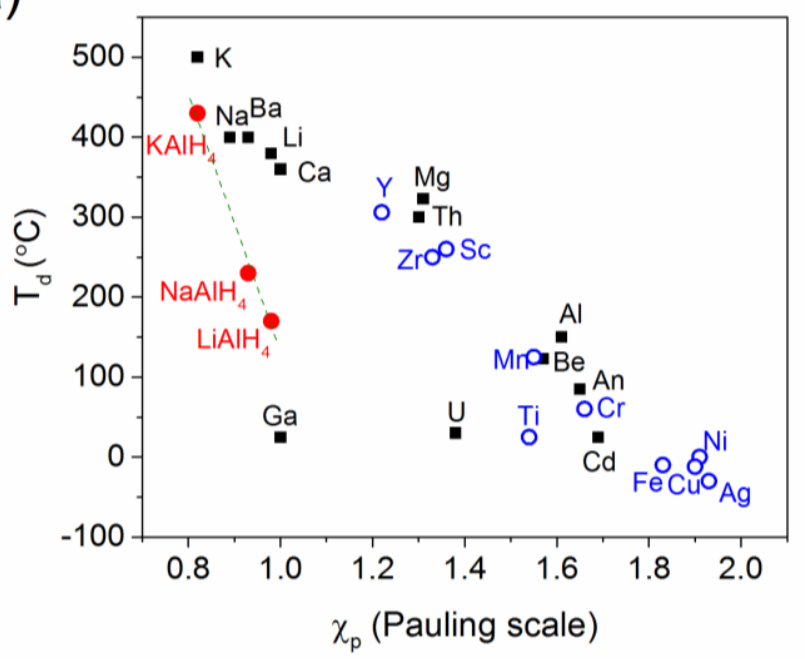

b)

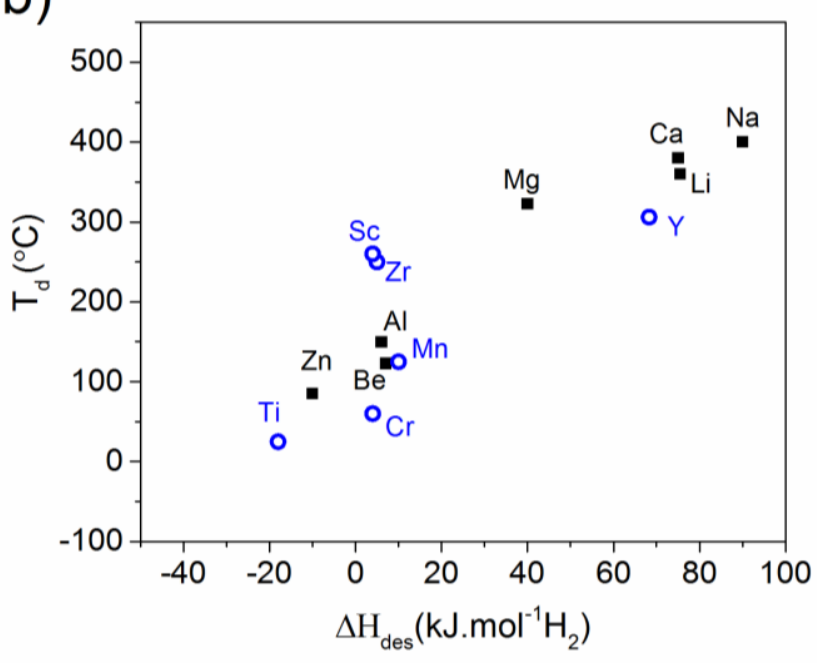


Figure 12

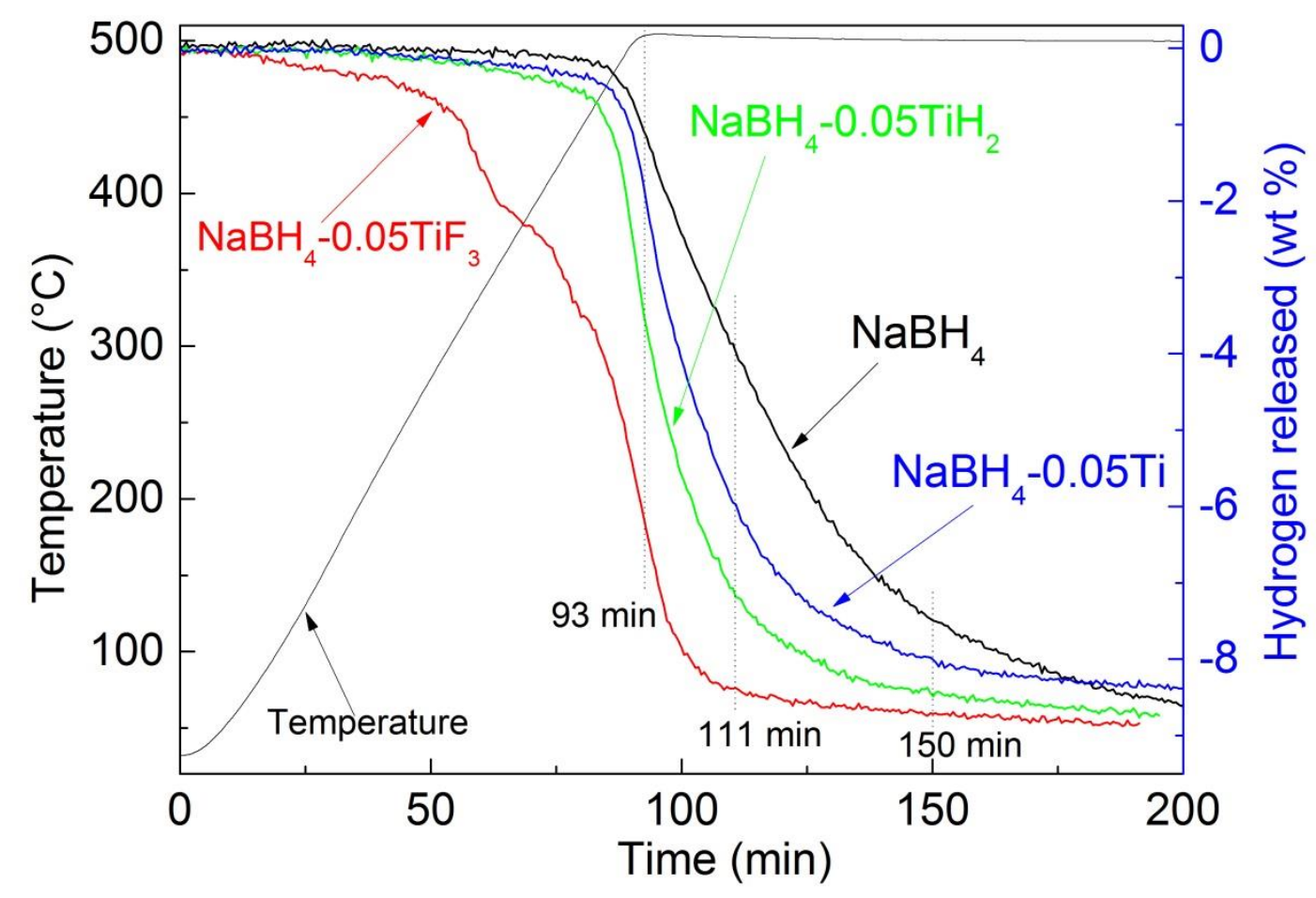




\section{Figure 13}

(a)

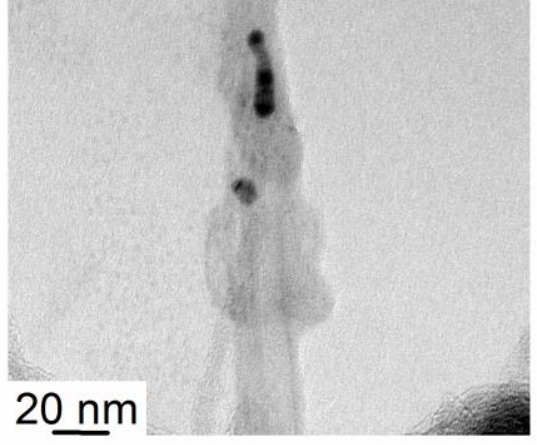

(d)

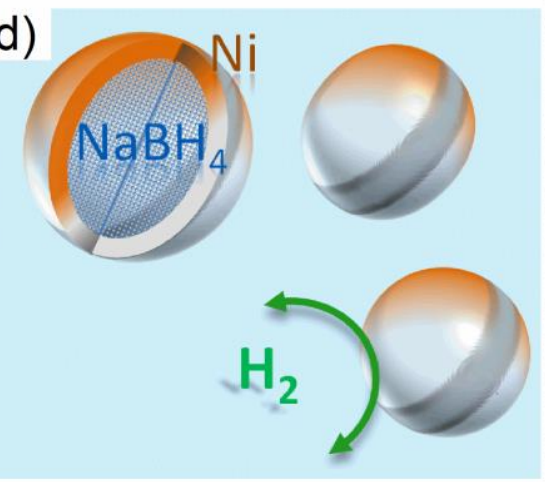

(b)

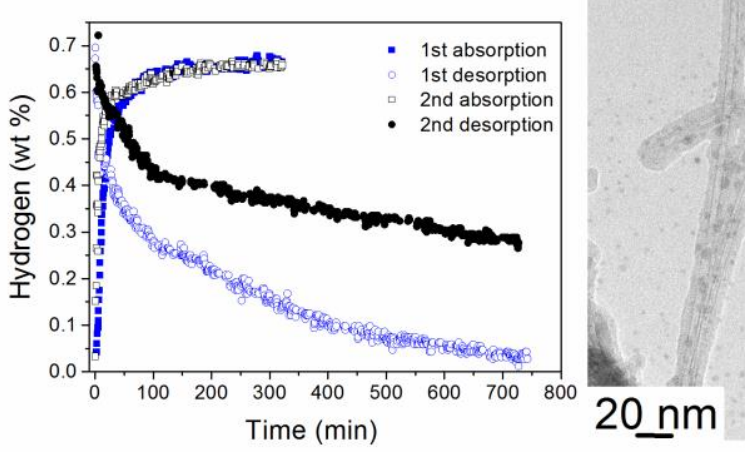

(c)

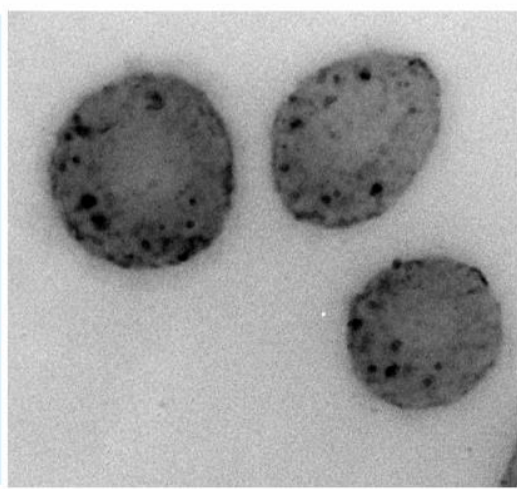

(e)

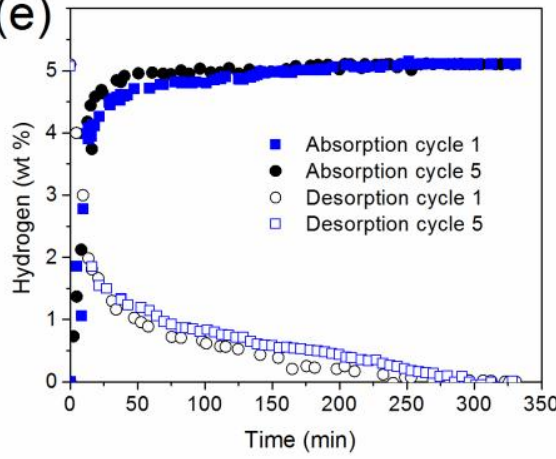




\section{Figure 14}

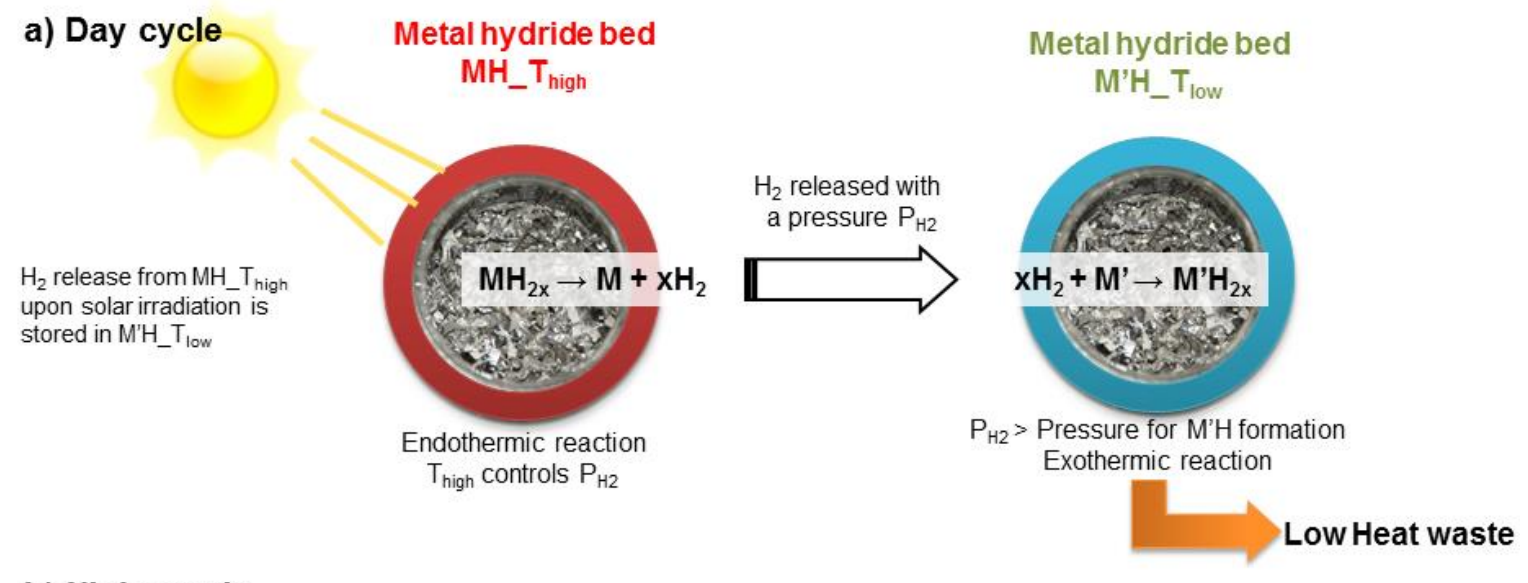

\section{b) Night cycle}

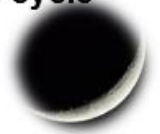

$\mathrm{H}_{2}$ release from $M^{\prime} \mathrm{H}_{-} \mathrm{T}_{\text {low }}$ generates heat through MH_T

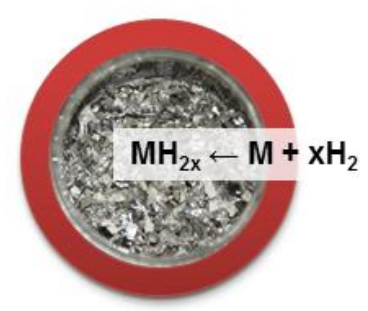

$\mathrm{H}_{2}$ released with a pressure $\mathrm{P}_{\mathrm{H} 2}$

$\mathrm{P}_{\mathrm{H} 2}>$ Pressure for $\mathrm{MH}$ formation Exothermic reaction

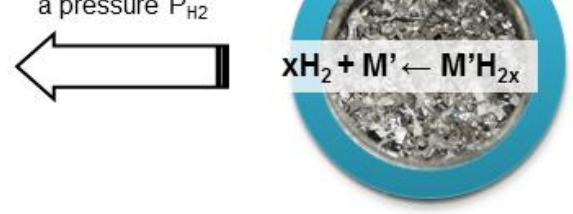

Endothermic reaction $\mathrm{T}_{\text {low }}$ controls $\mathrm{P}_{\mathrm{H} 2}$

Heat engine

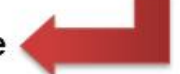

